\title{
A Preliminary Analysis of Patent Trends for Sodium/Sulfur Battery Technology
}
M. B. Triplett
C. Winter
W. B. Ashton

July 1985

Prepared for the U.S. Department of Energy under Contract DE-AC06-76RLO 1830

Pacific Northwest Laboratory Operated for the U.S. Department of Energy by Battelle Memorial Institute 


\title{
DISCLAIMER
}

This report was prepared as an account of work sponsored by an agency of the United States Government. Neither the United States Government nor any agency thereof, nor any of their employees, makes any warranty, express or implied, or assumes any legal liability or responsibility for the accuracy, completeness, or usefulness of any information, apparatus, product, or process disclosed, or represents that its use would not infringe privately owned rights. Reference herein to any specific commercial product, process, or service by trade name, trademark, manufacturer, or otherwise, does not necessarily constitute or imply its endorsement, recommendation, or favoring by the United States Government or any agency thereof. The views and opinions of authors expressed herein do not necessarily state or reflect those of the United States Government or any agency thereof.

\author{
PACIFIC NORTHWEST LABORATORY \\ operated by \\ BATTELLE \\ for the \\ UNITED STATES DEPARTMENT OF ENERGY \\ under Contract DE-AC06-76RLO 1830
}

\begin{tabular}{|c|c|}
\hline \multicolumn{2}{|c|}{ Printed in the United States of America } \\
\hline \multicolumn{2}{|c|}{$\begin{array}{c}\text { Available from } \\
\text { National Technical Information Service }\end{array}$} \\
\hline \multirow{3}{*}{\multicolumn{2}{|c|}{$\begin{array}{c}\text { United States Department of Commerce } \\
5285 \text { Port Royal Road } \\
\text { Springfield, Virginia } 22161\end{array}$}} \\
\hline & \\
\hline & \\
\hline \multicolumn{2}{|c|}{ NTIS Price Codes } \\
\hline & \\
\hline \multicolumn{2}{|c|}{ Printed Copy } \\
\hline & Price \\
\hline Pages & Codes \\
\hline $001-025$ & $\mathrm{~A} 02$ \\
\hline $026-050$ & $\mathrm{~A} 03$ \\
\hline $051-075$ & $\mathrm{~A} 04$ \\
\hline $076-100$ & A05 \\
\hline $101-125$ & A06 \\
\hline $126-150$ & $\mathrm{~A} 07$ \\
\hline $151-175$ & $\mathrm{~A} 08$ \\
\hline $176-200$ & $\mathrm{~A} 09$ \\
\hline $201-225$ & A010 \\
\hline $226-250$ & A011 \\
\hline $251-275$ & $\mathrm{~A} 012$ \\
\hline $276-300$ & $A 013$ \\
\hline
\end{tabular}


PNL -5422

UC-94cb

A PRELIMINARY ANALYSIS OF PATENT TRENDS FOR SODIUM/SULFUR BATTERY TECHNOLOGY
M. B. Triplett
C. Winter
W. R. Ashton

July 1985

Prepared for the U.S. Department of Energy under Contract DE-ACOG-76RLO 1830

Pacific Northwest Laboratory

Richland, Washington 99352 



\section{ACKNOWLEDGMENTS}

The authors of this document would like to acknowledge the important contributions of several individuals who made this study possible. First, we appreciate the valuable support of Ms. Terry M. Levinson, Office of Energy Systems Research, U.S. Department of Energy. Terry's willingness to promote development of innovative methods to help understand technology change was the basis for conducting this research. Also, Dr. Albert R. Landgrebe and Mr. James E. Quinn of the Energy Storage Technologies Division, IJ.S. Department of Energy, provided excellent technical guidance and personal support throughout the entire study.

This study would not have been completed without the technical assistance of Dr. Ralph J. Brodd of the Amoco Research Laboratory. His knowledge of advanced battery technology was an invaluable aspect of the research. We also appreciate the support and technical review provided by Mr. Jonathon $W$. Hurwitch of the Rattelle-Columbus Laboratories. Finally, we want to acknowledge the editorial assistance provided by Ms. Judy Danko. 


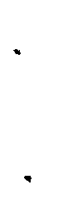




\section{EXECITTIVE SUMMARY}

This document summarizes development trends in sodium/sulfur battery technology based on data from U.S. patents. The purpose of the study was to use the activity, timing and ownership of $285 \mathrm{U}$.S. patents to identify and describe broad patterns of change in sodium/sulfur battery technology. The analysis was conducted using newly developed statistical and computer graphic techniques for describing technology development trends from patent data. This analysis suggests that for some technologies trends in patent data provide useful information for public and private R\&D planning.

BACKGROUND AND OBJECTIVES

Sodium/sulfur batteries are an attractive advanced battery concept with favorable characteristics for application in electric vehicles and utility load-leveling systems. Since its invention by Ford Motor Company in 1965, the technology has undergone significant public and private effort to develop reliable, long-life operational systems. However, even with significant federal support since 1974, sodium/sulfur batteries are still several years away from commercial applications. Important technical problems in system design and engineering remain and are being vigorously addressed. New developments are being patented both in this country and overseas.

Analysis of patent data is one of several ways to detect and measure the technological progress of R\&D programs. Patent data can indicate the level and nature of inventive technical efforts undertaken by firms and countries. In this study sodium/sulfur patent activity and ownership characteristics are used to describe certain aspects of development trends for the technology. More specifically, the objectives of this report are:

- to identify 11.S. and foreign leaders in sodium/sulfur battery technology and their areas of technical emphasis

- to describe emerging trends in areas of important sodium/sulfur battery development activity. 
RESEARCH APPROACH AND PRELIMINARY FINDINGS

After defining the aspects of sodium/sulfur battery R\&D to be studied, a systematic patent search and review by experts was undertaken to identify a complete set of relevant patents. Four key components (called "technology types") of sodium/sulfur battery systems were then defined to permit comparisons of research progress in important technical areas. A total of 285 patents issued through April 1, 1984, was identified during the patent search. The distribution of these patents in several categories is shown below:

\begin{tabular}{|c|c|c|c|c|c|}
\hline Assignee Sector & & & Assignee Region & & \\
\hline $\begin{array}{l}\text { Government and } \\
\text { Government Supported }\end{array}$ & 42 & $(14.8 \%)$ & U.S. & 165 & $\left(57.9^{\circ}\right.$ \\
\hline $\begin{array}{l}\text { Government Contractor } \\
\text { Not Supported }\end{array}$ & 36 & $(12.6 \%)$ & Non-U.S. & 120 & $(42.19$ \\
\hline Other U.S. Firms & 87 & $(30.5 \%)$ & Total & 285 & $100 \%$ \\
\hline Non-11.S. & 120 & $(42.1 \%)$ & & & \\
\hline Total & 285 & $100 \%$ & & & \\
\hline Assignee Country & & & Technology Type & & \\
\hline United States & 165 & $(57.9 \%)$ & Electrodes & 63 & $(22 \%)$ \\
\hline United Kingdom & 55 & $(19.3 \%)$ & Electrolytes & 92 & $(32 \%)$ \\
\hline West fermany & 28 & $(9.8 \%)$ & Seals/Containers & 67 & $(24 \%)$ \\
\hline France & 19 & $(6.7 \%)$ & General Design & 63 & $(22 \%)$ \\
\hline Japan & 17 & $(6.0 \%)$ & Total & 285 & $100 \%$ \\
\hline South Africa & 1 & $(0.3 \%)$ & & & \\
\hline Total & 285 & $100 \%$ & & & \\
\hline
\end{tabular}

A total of 51 assignees (29 1 J.S. and 22 foreign) held U.S. patents.

Patents selected in the search were analyzed by computer and several results were developed in light of the research objectives. The principal findings of this preliminary research are summarized below:

1. After Ford's patent in 1965, patent activity was fairly low (about 5 to 10 patents filed per year) until 1975 when it rose dramatically. 
Activity reached a peak in 1976 and 1977 (41 and 40 patents filed, respectively), but has declined steadily since 1977 .

2. The early U.S. dominance in development of sodium/sulfur batteries has declined substantially since 1974. While IJ.S. firms hold 58\% of all patents, foreign activity has outpaced that of the U.S. in recent years. Several viable international development efforts [e.g., United Kingdom (19\% of the patent set), West Germany (10\%), France $(7 \%)]$ are under way and appear to be stable. Notably, Japan's early patent effort has almost disappeared since the mid-1970s.

3. Typically, the development effort in foreign countries is concentrated in only one or two firms, whereas in the IJ.S. there have been several new entrants each year in addition to previously active firms.

4. U.S. and foreign countries are both active in the four technology areas studied in this research (electrodes, electrolytes, seals/containers, and general design). U.S. patents tend to emphasize electrolytes and seals/containers. Non-11.S. development focuses on electrodes and general design, and the electrolyte category to a lesser degree.

5. Although Ford still has a leading technological position overall, its historical predominance in this technology relative to other firms has recently diminished. Chloride Silent Power of the IInited Kingdom is generally well positioned alongside Ford and appears to have a stronger overall position relative to Brown Boveri(a) of West Germany. Since 1974, Chloride Silent Power has had a balanced emphasis in the four technical areas, while Ford has very small output in electrolytes. Chloride Silent Power's post-1974 patents are more highly cited than Ford's patents of the same period.

(a) Although incorporated in Switzerland, Brown Boveri was considered as West German for this study since all sodium/sulfur development occurred at a West German facility and was substantially funded by the West German government. 
6. The pattern of citations among the patents studied suggests that sodium/sulfur battery technology is a very closely knit area of activity. Outside technologies are rarely referred to, with ceramic forming methods being the most commonly referenced area. The age of the references given in sodium/sulfur patents is quite low relative to other patent sets that have been studied.

7. Experts in sodium/sulfur technology have indicated that these results confirm important development trends which are known through other sources (e.g. contact between professionals in the field and scientific literature). This suggests that patent trend analys is provides useful empirical information for some technologies in public and private R\&D programs. Patent data can provide insights into the state of technical progress, inventions undergoing further development, technical approaches used and the areas emphasized by various assignees for emerging technologies.

The findings and the data in this document are limited to a preliminary review of $11 . S$. patents issued before April 1, 1984. Significant events occurring after that date, such as the decision by General Electric Company to discontinue development of sodium/sulfur technology, are not reflected in these results. Moreover, other potentially informative patent sources (especially foreign patent systems such as those in Japan, Great Rritain or West Germany) were not considered in this study. These other sources could provide more comprehensive findings in future patent-based studies. 


\section{GLOSSARY}

Knowledge of a number of technical terms that are rooted in patent law and the practices of the U.S. Patent Office is important for a full understanding of research involving patent information. Also, a number of special terms to describe various aspects of patent trend analysis are used in this study. A brief glossary of terms is included below:

Activity

Assignee

Basic Patent

Citation

Concentration

Dominance
- a patent indicator that reflects the amount of effort being expended to solve a particular technical problem.

- the legal owner of a patent.

- an early, core patent on the fundamental principles or configurations of a key invention in an area that receives numerous citations from later patents.

- the receipt by an earlier patent of a reference from a subsequent patent document whose inventive scope is legally limited by the claims in the earlier patent. The earlier patent receives a citation from the later patent, whereas the later patent document contains a reference to the earlier patent. See reference.

- a patent indicator measuring the number of assignees, inventors, countries, etc., active in a particular technology and the relative amounts of their inventive output.

Corporate Inventor - an inventor listed on a patent assigned to a private firm or corporation at the patent's date of issue.

- a patent indicator that reflects the relative strength of patent positions among assignees, inventors, countries, etc., based on the distribution of citations received. 
Immedi acy

Independent

Inventor

Indicator

In-set Patent

Involution

Novelty

Prior Art

Problem Domain

Reference
- a patent indicator that reflects the age of the prior art being referenced by a set of patents.

- an inventor listed on a patent that is either unassigned or was assigned to an individual at its date of issue.

- one of a family of measures used to characterize some aspect of technology change based on patent data.

- a patent included in a specifically defined group or set of patents under study (see patent study set).

- a patent indicator that reflects the relative proportion of references given to patents within the defined set of patents (in-set) versus those references given to patents outside the set (out-of-set).

- a legal requirement for receiving a patent, i.e., an invention must be new or not previously known or used.

Out-0f-Set Patent - a patent outside of a specifically defined group or set of patents (see patent study set).

Patent Study Set - a group or set of patents that is being studied for information on technology trends in a particular technology or business area of interest.

- the body of previous patents that determines the scope of a given patent applicant's claims.

- some aspect of a technology's functional performance that can be addressed by certain technical developments or solutions and that may be the focus of patent activity.

- the identification on a patent document of an earlier patent whose claims relate to the scope of the later patent which mentions it. See Citation. 
Sector

Self-Citation
- a description of the type of assignee, e.g., corporate, government agency, independent inventor.

- the number or proportion of citations received from an assignee's own patents relative to citations received from other assignee's patents. 
. 


\section{CONTENTS}

ACKNOWLEDGMENTS $\ldots \ldots \ldots \ldots \ldots \ldots \ldots \ldots \ldots \ldots \ldots \ldots \ldots \ldots \ldots \ldots \ldots \ldots \ldots \ldots \ldots \ldots \ldots \ldots \ldots$

EXECIJTIVE SUMMARY $\ldots \ldots \ldots \ldots \ldots \ldots \ldots \ldots \ldots \ldots \ldots \ldots \ldots \ldots \ldots \ldots \ldots \ldots \ldots \ldots \ldots \ldots \ldots$

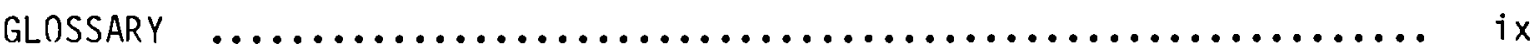

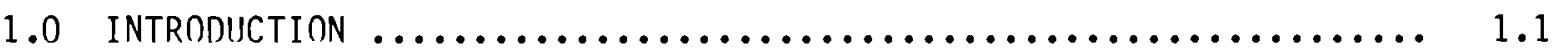

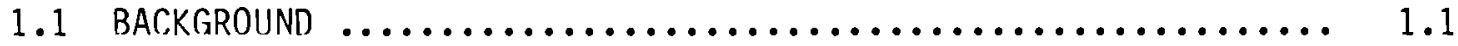

1.2 RESEARCH OBJECTIVES AND SCOPE $\ldots \ldots \ldots \ldots \ldots \ldots \ldots \ldots \ldots \ldots \ldots \ldots \ldots \ldots \ldots \ldots .2$

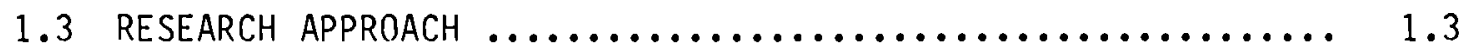

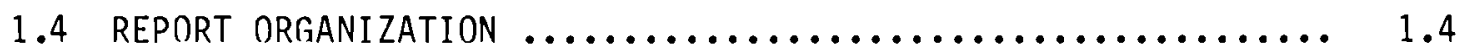

2.0 DEFINITION OF THE SODIUM/SULFIR PATENT DATA SET $\ldots \ldots \ldots \ldots \ldots \ldots \ldots$

2.1 SODIUM/SIULFUR BATTERY TECHNOLOGY $\ldots \ldots \ldots \ldots \ldots \ldots \ldots \ldots \ldots . \ldots \ldots$

2.2 SODIUMYSULFUR PROBLEM DOMAIN $\ldots \ldots \ldots \ldots \ldots \ldots \ldots \ldots \ldots \ldots \ldots \ldots \ldots \ldots \ldots \ldots$

2.2.1 Patent Technology Categories ................. 2.2.

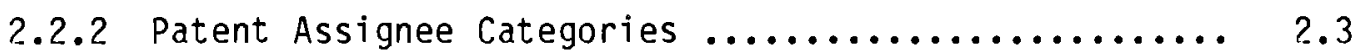

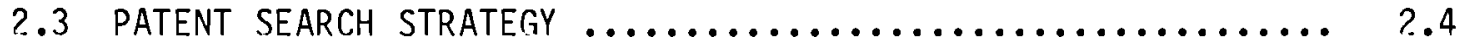

2.4 PATENT SEARCH RESULTS AND PATENT DATA SET SUMMARY ........ 2.5

3.0 AN OVERVIEW OF PATENT ASSigneE CHARACTERISTICS $\ldots \ldots \ldots \ldots \ldots \ldots \ldots . . . . .$.

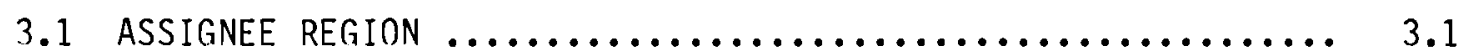

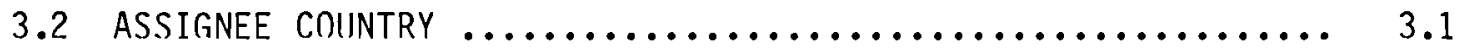

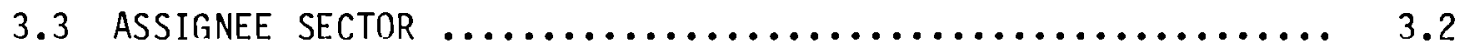

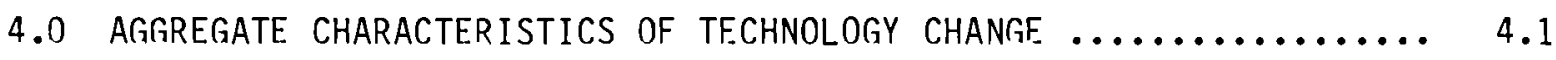

4.1 PATENT ACTIVITY $\ldots \ldots \ldots \ldots \ldots \ldots \ldots \ldots \ldots \ldots \ldots \ldots \ldots \ldots \ldots \ldots \ldots \ldots . \ldots \ldots$

4.2 THE SODIUM/SIULFUR TECHNOLOGY BASE $\ldots \ldots \ldots \ldots \ldots \ldots \ldots \ldots \ldots . .2$

4.3 THE AGE OF THE SODIUM/SULFUR TECHNOLOGY BASE .......... 4.4 
5.0 COMPARISON OF U.S. AND FOREIGN PATENT ACTIVITY $\ldots \ldots \ldots \ldots \ldots \ldots \ldots . . . .$.

5.1 TIME SERIES OF FOREIGN AND IJ.S. ACTIVITY ............ 5.1

5.2 ACTIVITY BY COUNTRY $\ldots \ldots \ldots \ldots \ldots \ldots \ldots \ldots \ldots \ldots \ldots \ldots \ldots \ldots \ldots \ldots \ldots \ldots \ldots \ldots \ldots .2$

5.3 AREAS OF TECHNOLOGY EMPHASIS $\ldots \ldots \ldots \ldots \ldots \ldots \ldots \ldots \ldots \ldots \ldots \ldots \ldots \ldots \ldots \ldots$

6.0 COMPARISON OF U.S. AND FOREIGN ASSIGNEES $\ldots \ldots \ldots \ldots \ldots \ldots \ldots \ldots \ldots .6 .1$

6.1 OVERALL ASSigneE CHARACTERISTICS ................. 6.1

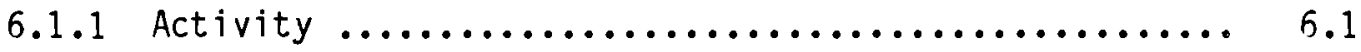

6.1 .2 Number of Inventors $\ldots \ldots \ldots \ldots \ldots \ldots \ldots \ldots \ldots \ldots \ldots . \ldots \ldots . . \ldots \ldots$

6.1 .3 Areas of Emphasis $\ldots \ldots \ldots \ldots \ldots \ldots \ldots \ldots \ldots \ldots \ldots . \ldots \ldots \ldots$

6.1 .4 Patent Citations $\ldots \ldots \ldots \ldots \ldots \ldots \ldots \ldots \ldots \ldots \ldots \ldots . \ldots \ldots \ldots$

6.1 .5 Patent References $\ldots \ldots \ldots \ldots \ldots \ldots \ldots \ldots \ldots \ldots \ldots \ldots . \ldots \ldots$

6.2 PATENT CITATION ANALYSIS $\ldots \ldots \ldots \ldots \ldots \ldots \ldots \ldots \ldots \ldots \ldots \ldots \ldots \ldots \ldots \ldots \ldots \ldots \ldots$

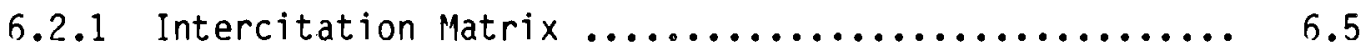

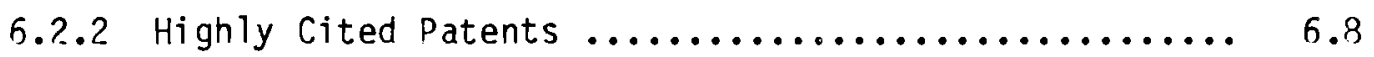

6.3 PROFILES OF MAJOR ASSIGNEES $\ldots \ldots \ldots \ldots \ldots \ldots \ldots \ldots \ldots \ldots \ldots \ldots \ldots \ldots \ldots \ldots$

6.3.1 Department of Energy/Ford/Dow Chemical .......... 6.12

6.3.2 General Electric/Electric Power Research Institute .. $\quad 6.12$

6.3 .3 Other II.S. Assignees ..................... 6.13

6.3 .4 Japanese Assignees $\ldots \ldots \ldots \ldots \ldots \ldots \ldots \ldots \ldots \ldots \ldots \ldots . \ldots \ldots \ldots \ldots$

6.3 .5 British Assignees ............................. 6.14

6.3.6 Brown Boveri \& Cie ...................... 6.15

6.3.7 Compagnie Generale d'Electricite $\ldots \ldots \ldots \ldots \ldots \ldots \ldots .6 .15$

REFERENCES $\ldots \ldots \ldots \ldots \ldots \ldots \ldots \ldots \ldots \ldots \ldots \ldots \ldots \ldots \ldots \ldots \ldots \ldots \ldots \ldots \ldots \ldots \ldots \ldots \ldots$

RELATED MATERIALS $\ldots \ldots \ldots \ldots \ldots \ldots \ldots \ldots \ldots \ldots \ldots \ldots \ldots \ldots \ldots \ldots \ldots$

APPENDIX A: SODIUM/SULFUR PATENT ANALYSIS DATA $\ldots \ldots \ldots \ldots \ldots \ldots \ldots \ldots$...

APPENDIX B: PROFILE OF SODIUM/SIILFIIR BATTERY PATENTS $\ldots \ldots \ldots \ldots \ldots \ldots$... B.1 


\section{FIGURES}

2.1 Technology Categories for Sodium/Sulfur Battery Patents ...... 2.2

4.1 Sodium/Sulfur Patent Activity $\ldots \ldots \ldots \ldots \ldots \ldots \ldots \ldots \ldots \ldots \ldots \ldots \ldots \ldots \ldots \ldots$

4.2 Patent Activity by Technology Type $\ldots \ldots \ldots \ldots \ldots \ldots \ldots \ldots \ldots \ldots \ldots . \ldots . \ldots$

4.3 Involution: Percent of In-Set References ............... 4.4

4.4 Immediacy: Average Age of References $\ldots \ldots \ldots \ldots \ldots \ldots \ldots \ldots \ldots \ldots$

5.1 Activity: Foreign Versus United States $\ldots \ldots \ldots \ldots \ldots \ldots \ldots \ldots \ldots . \ldots$

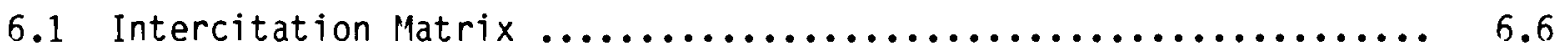

\section{TABLES}

3.1 Patent Activity by Assignee Region/Technology Type ........... 3.1

3.2 Patent Activity by Assignee Country/Technology Type .......... 3.2

3.3 Patent Activity by Assignee Sector/Technology Type .......... 3.2

4.1 Involution by Technology Type $\ldots \ldots \ldots \ldots \ldots \ldots \ldots \ldots \ldots \ldots \ldots \ldots \ldots$

5.1 Patent and Assignee Activity by Country $\ldots \ldots \ldots \ldots \ldots \ldots \ldots . \ldots . \ldots$

5.2 Highly Cited Patents Versus Overall Patent Activity

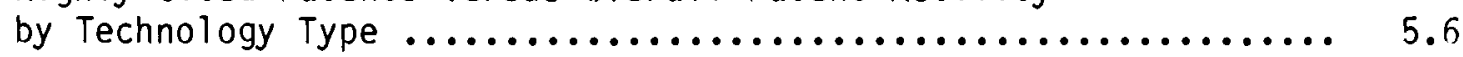

6.1 Patent Characteristics of Major Assignees $\ldots \ldots \ldots \ldots \ldots \ldots \ldots \ldots .2$

6.2 Patents Receiving Ten or More Citations ................. 6.9

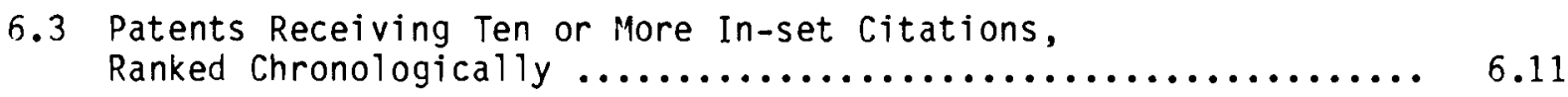

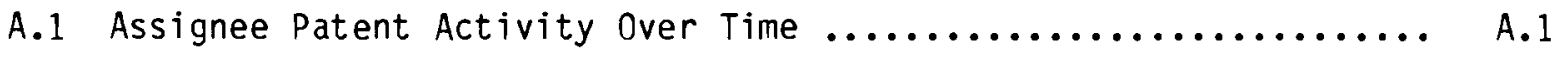

A.2 U.S. Versus Foreign Activity by Technology Type Over Time ...... A.2

A.3 Patent Characteristics Over Time by Technology Type .......... A.3

A.4 Involution Over Time $\ldots \ldots \ldots \ldots \ldots \ldots \ldots \ldots \ldots \ldots \ldots \ldots \ldots \ldots \ldots \ldots \ldots \ldots \ldots \ldots \ldots \ldots \ldots$

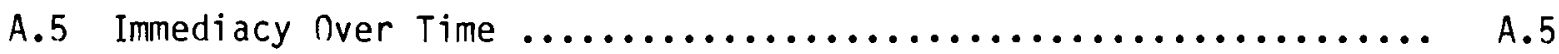

A.6 Patent Characteristics of Sodium/Sulfur Assignees $\ldots \ldots \ldots \ldots \ldots$... 6 
. 


\subsection{INTRODUCTION}

This document presents a data summary and preliminary findings to describe development trends in sodium/sulfur battery technology based on data from II.S. patents. The study was sponsored by the Office of Energy Systems Research, U.S. Department of Energy. The study focuses on identifying and describing broad patterns of change in sodium/sulfur technology as indicated by 285 U.S. patents. This analysis suggests that patent studies of some technologies provide useful empirical information for public and private R\&D planning.

\subsection{BACKGROUND}

Sodium/sulfur battery technology was invented by the Ford Motor Company in 1965. Because of their high energy storage density and favorable charge and discharge characteristics, sodium/sulfur batteries have been promoted for use in electric vehicles and in load-leveling for electric utilities. Following the oil embargo in the early 1970s, development effort was boosted by federal funding that has continued to the present. Federal funding has fallen off recently and some firms have relied on internal funds as the technology continues to mature.

Patent data provide a unique view of the process of technology development for areas of high long-term interest such as the sodium/sulfur battery. Information contained in patents can indicate who is active in developing the technology, the level of inventive effort, and the direction of inventive activity. It is often difficult to describe the relative technological positions of firms who are developing new and emerging technologies such as sodium/sulfur batteries. Instead of competing within a marketplace, firms compete to produce potentially marketable ideas in the form of patents. These patents, and the ideas that they represent, provide the basis for future technology developments and commercial market positions.

Patent data analysis is a relatively new technique for analyzing technology change (Campbell 1983). Although useful for studying the positions of private firms in technological markets, its value for planning and evaluating large public sector R\&D programs has not been established. This study 
describes development trends for sodium/sulfur batteries in an effort to clarify the potential role of patent information in federal research. Several planning and policy questions important in research in the sodium/sulfur battery provided the background for this study:

- What is the United States' patent position relative to that of other countries? How does the level of effort or the technological emphasis differ?

- What has been the impact of federal funding on sodium/sulfur battery technology? To what extent has the technology been transferred to the private sector or have means been established for development of its commercial potential?

- What are the relative patent positions of firms within this technological area?

Patent data provide one useful input to an analysis of these issues.

\subsection{RESEARCH OBJECTIVES AND SCOPE}

This study presents a preliminary analysis of the nature and sources of developments in sodium/sulfur battery technology based on 11.S. patent data. The research will be limited to a description of the general characteristics of patent activity and assignees for the major sodium/sulfur technology areas. The specific objectives of the research in this volume are as follows:

- to identify II.S. and foreign leaders in sodium/sulfur battery technology and their areas of technical emphasis

- to describe emerging trends in areas of important sodium/sulfur battery development activity.

This research is not intended to be an exhaustive analysis of sodium/sulfur patent data. The study focuses on assembling patent data pertinent to the issues above and cataloging it into a form useful for both preliminary findings and further detailed review. 


\subsection{RESEARCH APPROACH}

In this analysis certain key information is extracted from U.S. patents and analyzed using statistical and computer graphics techniques. The patent data are distilled into several aggregate measures called patent trend indicators which are used to identify and understand the nature of changes represented by patent activity. Identification of trends in the data over time--including patent relationships between firms and technology areas--are an important part of the study. The analysis follows the general research approach outlined below:

1. After the research objectives for the study were formulated, the specific technical areas to be covered were defined. This process included specifying the particular technical problem domain of the sodium/sulfur technology being studied. A problem domain is some aspect of a technology's functional performance that can be addressed by certain technical developments or solutions and that may be the focus of important patent activity.

2. The sodium/sulfur technology was then categorized into technical subgroups or system components relevant to the overall problem domain. The resulting classification helps to identify relevant patents and allows comparative analyses of development activity, technical linkages, and assignees for patent subgroups or technical areas of interest. For this study, individual patents were also categorized according to particular groups of assignees, such as government, universities, government-supported private firms, etc., to permit comparisons of the roles various organizations played in developing the technology.

3. The patent search activity was conducted next; its purpose is to identify those patents which pertain to the analysis and to construct the patent study data set. Information on each relevant patent is then entered into a computerized data base management system for subsequent editing and analysis. The information included on each patent in this study is shown below: 
- Patent Number

- Issue nate

- Filing Date

- Title

- Assignee Name
- Assignee Sector(a)

- Assignee Country

- Technology or Application Category

- Inventor Name

- Patent Reference

4. After the patent data base was constructed, computer analys is and interpretation of the patent data were completed.

\subsection{REPORT ORGANIZATION}

Section 2.n hriefly summarizes sodium/sulfur technology and the federal role in supporting its development. In addition, the hasis for defining the patent set is established in terms of the rules for determining which patents were relevant to the study and the manner in which patents have heen categorized. Section 3.0 describes several features of the major assignee groups and their roles in technical developments to date. Section 4.0 presents the general characteristics of the technology and its development over time as seen through patent data. Section 5.0 focuses more specifically on a comparison of U.S. and foreign activity. Section 6.0 compares the patent positions of specific firms involved in the development of this technology. Finally, several additional data tables and a list of patents analyzed in this study are presented in the appendices.

(a) Sector refers to a descriptive categorization of assignees as corporate, government agency, or independent inventor. 


\subsection{DEFINITION OF THE SODIUM/SULFUR PATENT DATA SET}

The foundation for conducting patent trend studies is the identification of an accurate set of relevant patents. This section presents the steps taken to identify a relevant patent data set and describes the patent categories used to distinguish among technical areas of emphasis and types of assignees.

\subsection{SODIUM/SULFUR BATTERY TECHNOLOGY}

Sodium/sulfur batteries contain electrodes composed of molten sodium and sulfur separated by a solid electrolyte material, either a ceramic or glass. The technology is attractive for use in electric vehicles and in load leveling for electric utilities. Its advantages relative to other battery technologies follow chiefly from a combination of the following characteristics:

- high specific energy (watt-hours $/ \mathrm{kg}$ )

- high utilization efficiency (ratio of discharge/charge)

- relatively flat power level throughout discharge.

Recent research has focused on obtaining low-cost electrolyte materials with suitable operating characteristics and on designing containers and seals so as to have cells with long-life characteristics. Some development aimed at obtaining reliable battery systems has also dealt with the problems of cell interconnection methods. Many innovations resulting from each of these lines of activity have been protected through patents.

\subsection{SODIUM/SULFUR PROBLEM DOMAIN}

A problem domain is considered to be some aspect of a technology's functional performance that can be addressed by certain types of technical developments or solutions and that may be the focus of important patent activity. Usually a problem domain represents technical issues or difficulties that must be overcome before a technology can become commercially viable. These issues may include cost or operating performance (e.g. reliability, ease of use), key technical barriers to commercialization, or system design characteristics. In any case, a problem domain specifies areas that are the focus of inventive 
activity. Thus, definition of the appropriate problem domain is an important aspect of identifying patents relevant to a particular study.

Given the objectives of this study, the problem domain was defined as the major technical barriers to future development of commercial battery systems. Thus, patents that address important engineering and cost problems were selected for analysis. The technical development problems selected for analysis were as follows:

- preventing fracture of the electrolyte materials

- containing the corrosive battery components for time periods needed in commercial applications

- producing low-cost, long-life materials.

llany patents that were relevant to the technology but not to current development problems were excluded from the research (e.g., "technology base" patents in ceramics, electrolytes, or design).

\subsubsection{Patent Technology Categories}

To organize the problem domain for this analysis, the technology breakdown shown in Figure 2.1 was developed. This categorization was used to identify relevant patents and to place them into groups for comparison. Each group

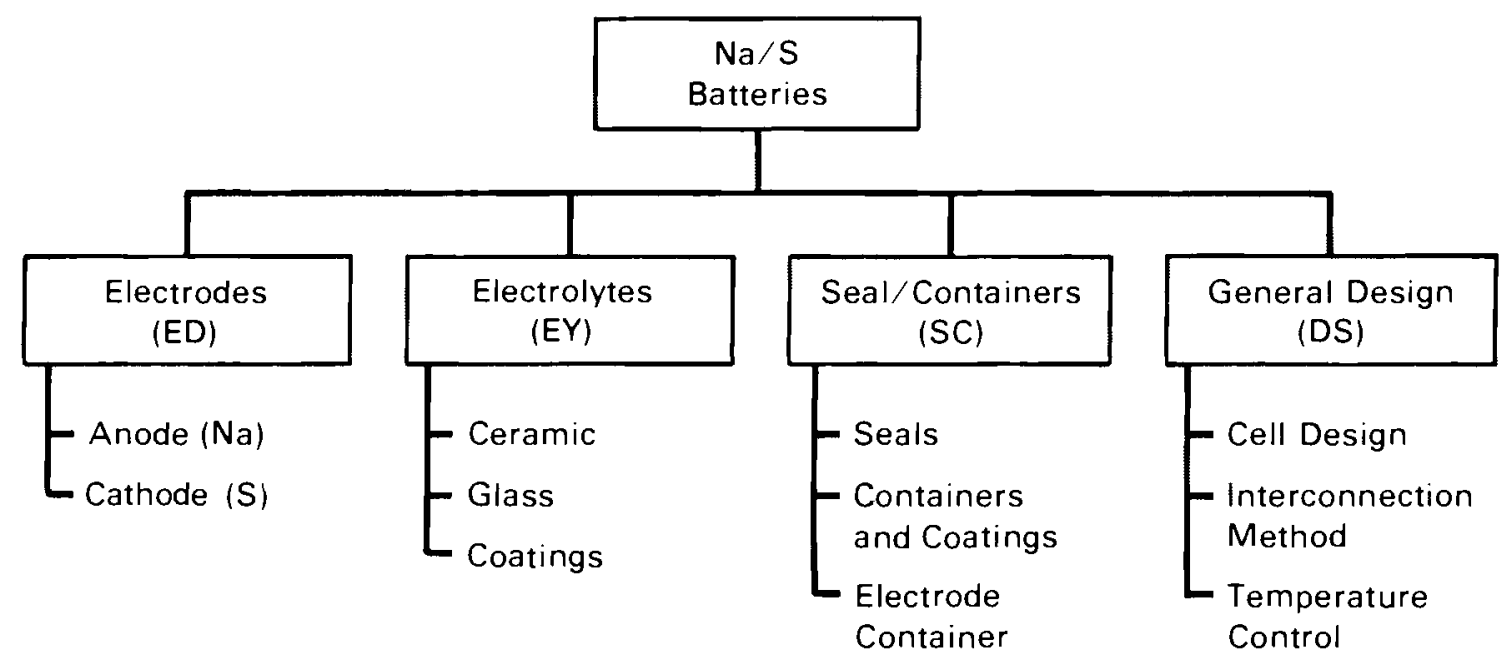

FIGURE 2.1. Technology Categories for Sodium/Sulfur Battery Patents 
represents a major area of research being undertaken to overcome technical problems that prevent development of a commercial battery. The four principal technology categories are described below:

(ED) Electrode materials, both anode (sodium) and cathode (sulfur), designs and fabrication methods. Innovations that address flow restrictions in the event of electrolyte failure were included.

(EY) Electrolyte materials and fabrication methods, both ceramics (beta alumina) and glasses, as well as coatings for these electrolytes. These innovations focused on producing long-lived and low-cost materials.

(SC) Seals/Containers and matters related to development of reliable and long-lived containers to withstand the high temperature and corrosive environment. Some innovations also focused on current collection methods.

(DS) General Design patents for overall cell designs, interconnection strategies for battery systems, and other issues related to overall battery operations such as temperature control.

\subsubsection{Patent Assignee Categories}

To better understand the contributions of federal funding to development of the sodium/sulfur technology, IJ.S. patent assignees were broken into categories. The categories were designed to allow comparisons of patent characteristics between government and private developments, where possible. The three major U.S. assignee groups are described below:

1. U.S. government-held or sponsored: these include patents held by the IJ.S. government, of which there are only 4 , and patents held by government contractors who acknowledge government support [e.g., the National Science Foundation (NSF), Energy Research and Development Administration (ERDA), U.S. Department of Energy (DOE), or the U.S. Army]. 
2. DOE (or NSF) contractor, not government-sponsored: these include patents filed before 1974 by Ford, Dow and others, as well as some later patents that did not acknowledge government support. (a)

3. Other U.S. assignees: General Electric, Electric Power Research Institute, Corning, Dupont, etc.

\subsection{PATENT SEARCH STRATEGY}

Relevant sodium/sulfur technology patents issued through April 1, 1984, were identified through a combination of search techniques and expert technical review of each patent. The specific search procedure consisted of the following four steps:

1. Keyword Search - A keyword search of patent Class 429--Chemistry, Electrical Current Producing Apparatus, Product, and Process-identified two subclasses that contained most of the patents: 429/104--Active material in molten state with solid-state electrolyte; 429/193--Include electrolyte composition chemically specified...Solid...Metal Oxide Component. All patents from these two subclasses were ordered.

2. Technical Patent Review - The 330 patents (issued between 1971 (b) and early 1984) from these two subclasses were reviewed for their technical relevance and 233 were selected. These patents formed the basis for the remaining search steps.

3. Out-of-Set Reference Screening - Patents frequently cited by the patents in step 2, many of which were issued prior to 1971, were identified. From this additional set, any patent not already

(a) While Category 1 patents acknowledge government support, some Category 2 patents may still have been partially supported by government funds. At the present time, there is no legal obligation for assignees to acknowledge even partial government support for patented work.

(b) The data base selected for this step of the search did not include information on patents issued before 1971. 
identified but having four or more citations was selected and screened for relevance. These sets overlapped substantially; however, 18 new patents were added.

4. Dut-of-Set Citation Screenings - An additional set of candidate patents was identified from those which cited the patents in steps 2 and 3. After a technical screening, 34 patents had been added, many of them fairly recent.

Relevant patents were found in several additional patent subclasses within Class 429 and in other patent classes as we11. Among the most common classes were the following:

- 204/195S - Chemistry, Electrical and Wave Energy--Solid Electrolyte Apparatus

- $429 / 103$ - With fused electrolyte

- 29/623.2 - Metal Working--Electric Rattery Cell...including Sealing

- 264 - Plastic and Non-Metallic Article Shaping or Treating...Pore forming in situ...including vitrification or firing

- 106 - Composition, Coating or Plastics.

The relevance of each patent to the problem domain of the study had to be established; this was not always a clear-cut decision. Some patents, especially those related to electrolyte materials, might emphasize technologies outside the immediate field of sodium/sulfur battery technology. Other patents might relate primarily to other battery technologies, but have enough relevance to sodium/sulfur technology to be included in the set. Many of the patents that were rejected dealt with solid electrolyte systems for other battery types and solid electrolyte systems for instrumentation devices such as oxygen sensors.

\subsection{PATENT SEARCH RESULTS AND DATA SET SUMMARY}

The patent search and screening process resulted in a final total of 285 patents for analysis. The patent search identified U.S. patents that issued up through April 1, 1984. Since most U.S. patent applications take approximately 
24 months to issue, this means that patent activity results for 1981-1984 probably do not include all patents filed during those years. The overall composition of the study data set (number of patents) for several categories of interest is shown below:

\begin{tabular}{|c|c|c|c|c|c|}
\hline \multicolumn{3}{|l|}{ Technology Type } & \multicolumn{2}{|c|}{ Assignee Region } & \multirow[b]{2}{*}{$(57.9 \%)$} \\
\hline Electrodes & 63 & $(22.1 \%)$ & Inited States & 165 & \\
\hline Electrolytes & 92 & $(32.2 \%)$ & Non-U.S. & 120 & $(42.1 \%)$ \\
\hline Seals/Containers & 67 & $(23.5 \%)$ & Total & 285 & $100 \%$ \\
\hline General Design & 63 & $(22.1 \%)$ & & & \\
\hline Total & 285 & $100 \%$ & & & \\
\hline Assignee Sector & & & \multicolumn{2}{|c|}{ Assignee Country } & \\
\hline $\begin{array}{l}\text { Government and } \\
\text { Government Supported }\end{array}$ & $4 ?$ & $(14.8 \%)$ & United States & 165 & $(57.9 \%)$ \\
\hline $\begin{array}{l}\text { Government Contractor } \\
\text { Not Supported }\end{array}$ & 36 & $(12.6 \%)$ & Innited Kingdom & 55 & $(19.3 \%)$ \\
\hline Other II.S. Firms & 87 & $(30.5 \%)$ & West Germany & 28 & $(9.8 \%)$ \\
\hline Non-11.S. & 120 & $(42.1 \%)$ & France & 19 & $(6.7 \%)$ \\
\hline \multirow[t]{3}{*}{ Total } & 285 & $100 \%$ & Japan & 17 & $(6.0 \%)$ \\
\hline & & & South Africa & 1 & $(0.3 \%)$ \\
\hline & & & Total & 285 & $100 \%$ \\
\hline
\end{tabular}

A total of 51 individual assignees (29 U.S. and 22 foreign) held U.S. patents. They are listed along with several of their patent characteristics in Appendix A. The 285 patents, grouped alphabetically by assignee, are listed in Appendix $B$. 


\subsection{AN OVERVIEW OF PATENT ASSIGNEE CHARACTERISTICS}

This section presents a general comparison of several assignee groups for the sodium/sulfur technology types defined in this research. The data include only aggregate tabulations. More detailed comparisons by assignee and by year are presented in Sections $4.0,5.0$ and 6.0 .

\subsection{ASSIGNEE REGION}

Table 3.1 shows a breakdown of patent activity by assignee region (U.S. vs. non-U.S.) and by technology type. For the most part, foreign patent activity closely parallels that of the U.S. One significant difference, however, appears in the relative emphasis placed upon the technical areas of the sodium/sulfur technology. U.S. activity is much more heavily concentrated in electrolytes and seals and containers; foreign activity is more concentrated in electrodes and general design. The I.S. activity seems to emphasize the development of: 1) reliable, low-cost electrolyte materials and 2) long-lived, corrosion-resistant containers.

\subsection{ASSIGNEE COUNTRY}

Table 3.2 presents a breakdown of patent activity by assignee country and technology type. Major foreign patent positions are held by firms in the

TABLE 3.1. Patent Activity by Assignee Region/Technology Type

\begin{tabular}{|c|c|c|c|c|c|c|c|c|c|c|}
\hline \multirow[b]{2}{*}{ Assignee Region } & \multicolumn{8}{|c|}{ Technology Type } & \multirow[b]{2}{*}{ Tota 1} & \multirow[b]{2}{*}{$\%$} \\
\hline & \multicolumn{2}{|c|}{ Electrodes } & \multicolumn{2}{|c|}{ Electrolytes } & \multicolumn{2}{|c|}{$\begin{array}{c}\text { Seals/ } \\
\text { Containers } \\
\end{array}$} & \multicolumn{2}{|c|}{$\begin{array}{l}\text { General } \\
\text { Design } \\
\end{array}$} & & \\
\hline United States & 29 & $(18 \%)$ & 61 & $(37 \%)$ & 49 & $(30 \%)$ & 26 & $(15 \%)$ & 165 & 57.9 \\
\hline \multirow{2}{*}{ Non-U.S. } & 34 & $(28 \%)$ & 31 & $(26 \%)$ & 18 & $(15 \%)$ & 37 & $(31 \%)$ & 120 & 42.1 \\
\hline & 63 & & 92 & & 67 & & 63 & & 285 & 100 \\
\hline
\end{tabular}

Note: Table entries in parentheses are row percentages. 
TABLE 3.2. Patent Activity by Assignee Country/Technology Type

\begin{tabular}{|c|c|c|c|c|c|c|}
\hline \multirow[b]{2}{*}{ Assignee Country } & \multicolumn{4}{|c|}{ Technology Type } & \multirow[b]{2}{*}{ Total } & \multirow[b]{2}{*}{$\%$} \\
\hline & Electrodes & Electrolytes & $\begin{array}{c}\text { Seals/ } \\
\text { Containers } \\
\end{array}$ & $\begin{array}{l}\text { General } \\
\text { Design }\end{array}$ & & \\
\hline United States & 29 & 61 & 49 & 26 & 165 & 57.9 \\
\hline United Kingdom & 20 & 12 & 9 & 14 & 55 & 19.3 \\
\hline West Germany & 8 & 3 & 7 & 10 & 28 & 9.8 \\
\hline France & 1 & 8 & 1 & 9 & 19 & 6.7 \\
\hline Japan & 5 & 8 & - & 4 & 17 & 6.0 \\
\hline South Africa & - & $=$ & 1 & - & 1 & 0.3 \\
\hline Total & 63 & 92 & 67 & 63 & 285 & 100 \\
\hline
\end{tabular}

United Kingdom, West Germany, and France. This is especially true for electrode and general design patents. The U.S. has a dominant position in terms of total patent production, with very strong holdings in electrolytes and in seals/containers. Each major assignee country has some activity in each technology area, with the exception of France in electrodes and seals/containers, and Japan in seals/containers.

\subsection{ASSIGNFE SECTOR}

Table 3.3 contains a breakdown of patent activity by assignee sector. About half of the 165 patents held by II.S. assignees are held by firms other than government contractors. While the patents referred to as government supported explicitly acknowledge government support in the main body of the

TABLE 3.3. Patent Activity by Assignee Sector/Technology Type

\begin{tabular}{|c|c|c|c|c|c|c|}
\hline \multirow[b]{2}{*}{ Assignee Sector } & \multicolumn{4}{|c|}{ Technology Type } & \multirow[b]{2}{*}{ Total } & \multirow[b]{2}{*}{$\%$} \\
\hline & Electrodes & Electrolytes & $\begin{array}{c}\text { Seals/ } \\
\text { Containers } \\
\end{array}$ & $\begin{array}{l}\text { General } \\
\text { Design } \\
\end{array}$ & & \\
\hline $\begin{array}{l}\text { Government and } \\
\text { Government Supported }\end{array}$ & 11 & 12 & 10 & 9 & 42 & 14.8 \\
\hline $\begin{array}{l}\text { Government Contractor } \\
\text { Not Supported }\end{array}$ & 4 & 15 & 7 & 10 & 36 & 12.6 \\
\hline Other U.S. Firms & 14 & 34 & 32 & 7 & 87 & 30.5 \\
\hline All Foreign & 34 & 31 & 18 & 37 & $\underline{12 n}$ & 42.1 \\
\hline Total & 63 & 92 & 67 & 63 & 285 & 100 \\
\hline
\end{tabular}


patent, there may still be patents in the "government contractor not supported" group that were funded in part, or even in total, by government funds. Under present patent regulations assignees are not required to acknowledge government support. Although the estimate of government support may not be completely accurate, it does provide some indication of the status of government supported work in the overall evolution of sodium/sulfur battery technology.

For the third category, the Electric Power Research Institute (EPRI) has supported sodium/sulfur battery development principally through General Electric and indirectly through Chloride Silent Power in the United Kingdom (U.K.). A separate accounting of these patents has not been made; however, the EPRI and General Electric patents taken together should give a fair view of the level of effort and direction for EPRI funding.

Foreign governments, chiefly the U.K. and West Germany, have supported the development of this technology through private firms, much as the U.S. government has done. Recause there is no way to easily trace the source of funding for foreign-held patents, a separate breakdown was not made for patents supported by foreign governments. 


\subsection{AGGREGATE CHARACTERISTICS OF TECHNOLOGY CHANGE}

A series of indicators to describe technological change over time have been constructed from patent data (Campbell 1983, Campbell and Levine 1984). These indicators can be used to describe a particular patented technological area in terms of the overall level of inventive effort, the nature of the inventions (or technology) being developed, and the nature of the assignees (or inventors). This section summarizes the following key indicators for describing overall sodium/sulfur technology characteristics: 1) patent activity and the relative emphasis on the four technology types; 2) the degree to which sodium/sulfur battery technology draws upon work in other fields (known as involution); and 3) the age of the technology base from which sodium/sulfur technology is evolving.

\subsection{PATENT ACTIVITY}

The level of inventive effort depends upon the collective expectations of the individuals and firms working in a particular technological area. Inventors have expectations relative to the potential payoffs that are likely to accrue from inventive effort. Patent data on the number of patents filed over time provide insight into changes in the level of effort being expended. Inventive effort can also he measured by the number of inventors and the number of firms who are active at any given time.

Figure 4.1 shows the number of patents filed in each year since the original sodium/sulfur battery patent was filed hy Ford Motor Company in 1965. Activity remained low, about 5-10 patents per year, until 1975. Patent filings surged during the oil embargo and the ensuing interest in alternative energy sources and utilization methods.

Total activity peaked in 1976 and 1977 with 41 and 40 patents filed, respectively. Since 1977, however, patent filings have declined. The data for the final two years probably understate the true number of patent filings since some patents filed in that period are still pending. (In the U.S. patent system no information is publicly available on pending patent applications.) 


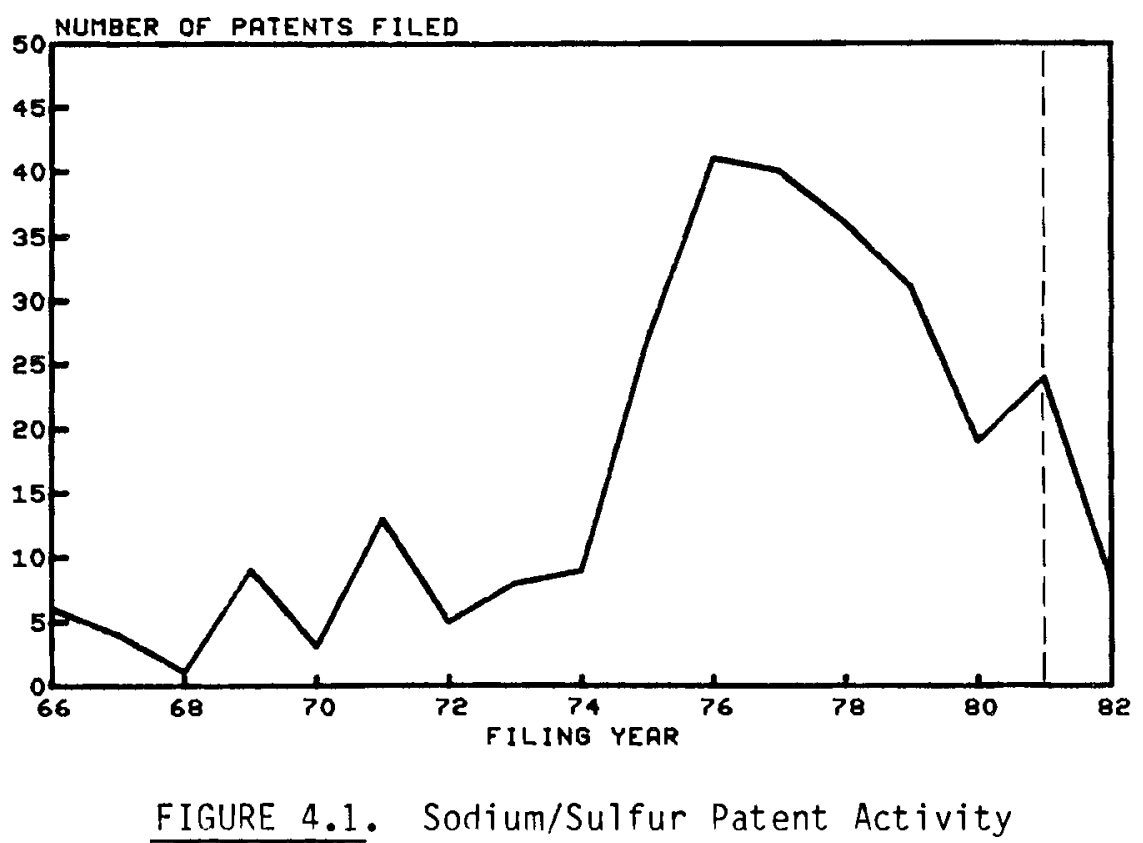

Consequently, it is likely that more than eight patents were actually filed in 198?. This effect is shown in all patent time series illustrations by a dashed line in the 1981 position.

Figure 4.? shows total patent activity and its makeup hy technology type. Refore 1974, activity was greatest in electrolyte materials. The peak in activity in 1976 and 1977 was associated with a rise in each of the four technology areas. Only the seals/containers category peaked after 1976, reaching its maximum in 1978 .

\section{4.? THE SONIUM/SILFUR TECHNOLOGY RASE}

Inventive activity usually huilds upon prior work in an area. In the patent system, strict standards of novelty for work are maintained to ensure that any invention represents a significant new advance over prior developments. To establish its relationship with the prior art, each patent must reference other patents that are closely related. These references provide useful information for determining what technical areas inventive activity is drawing upon. Involution, a patent-hased technology indicator, measures the percentage of "in-set" references, i.e., references made hy patents in the 


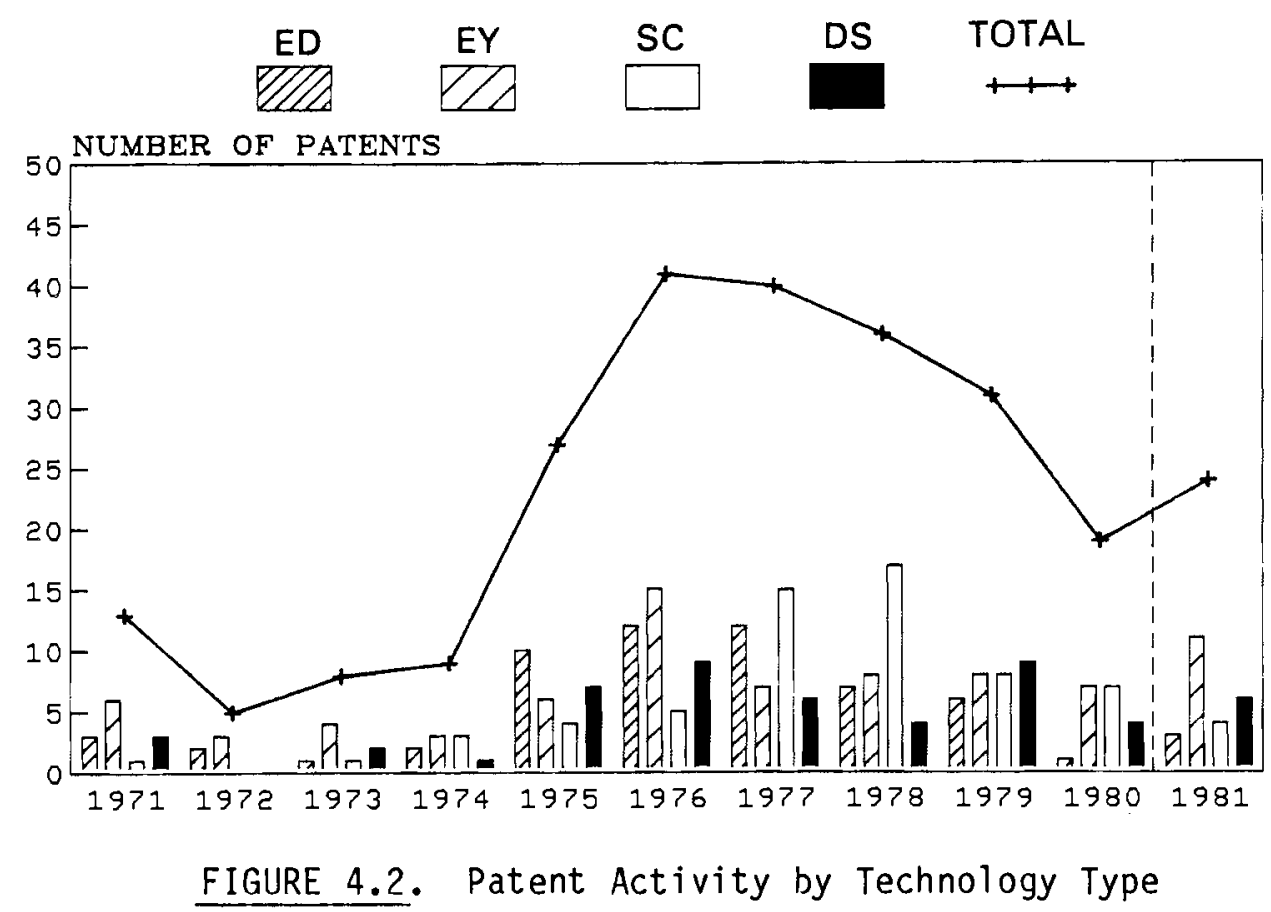

study set to other patents in the same patent set. ("Out-of-set" references are those references made to patents not included in the study set). In general, the higher the involution, the more self-contained the technology (since a high involution measure implies a high percentage of in-set references). Lower values of involution show a technology that draws heavily upon technical areas outside the patent study set.

Figure 4.3 shows involution over time for the sodium/sulfur patent set. As is typical in many developing technologies, involution is low early in the study period before the field has coalesced. Involution increases as development problems become more well-defined and the alternative approaches are specified. Later patents build upon or offer improvements to the existing art. For this set of 285 patents, $63.4 \%$ of the references were in-set references. This figure is very high relative to other technologies studied with patent analysis methods (Campbell and Levine 1984), and suggests that sodium/sulfur technology is more closely knit than those other technologies.

Involution has also been calculated for the patents in each of the four technology areas as shown in Table 4.1. The electrolyte patents have the 


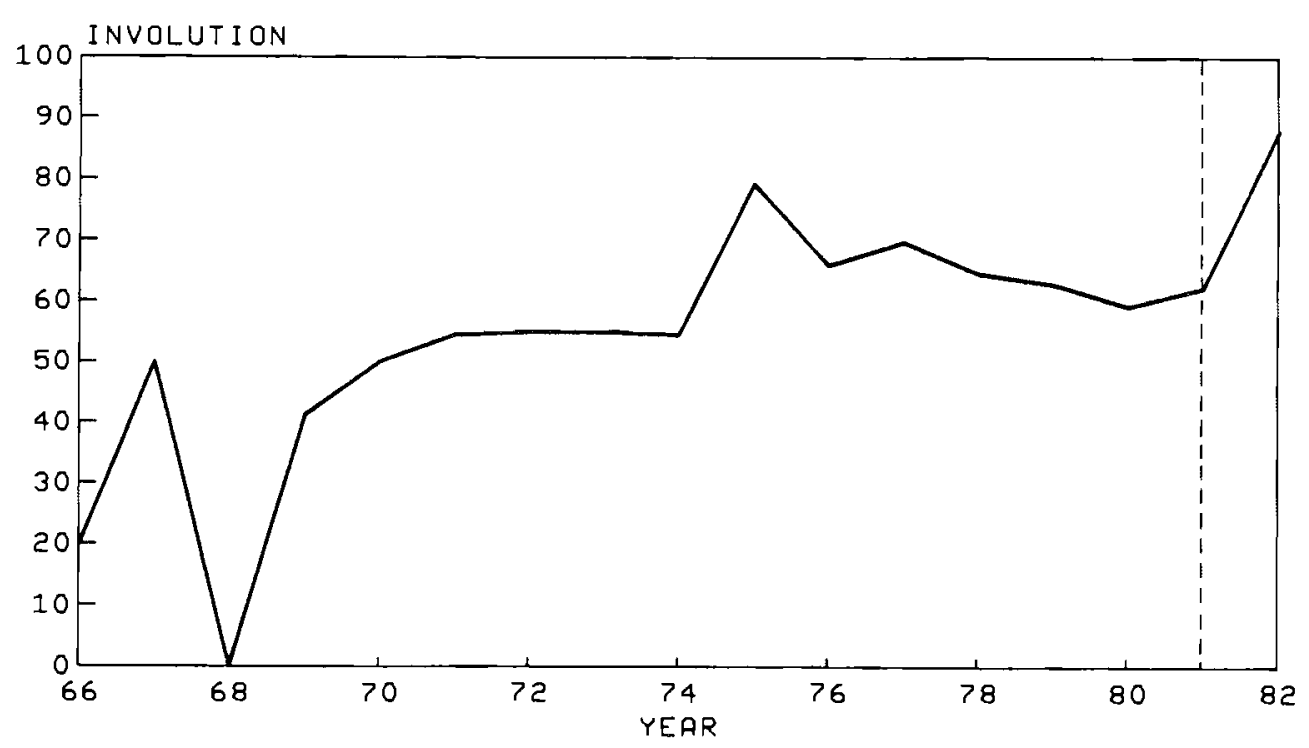

FIGIJRE 4.3. Involution: Percent of In-set References

TARLE 4.1. Involution by Technology Type

$\begin{array}{lc}\text { Technology Type } & \text { Involution Level } \\ \text { Electrodes } & 76.7 \% \\ \text { Electrolytes } & 54.1 \% \\ \text { Seals/Containers } & 62.8 \% \\ \text { General Design } & 65.5 \% \\ \text { Overall } & 63.4 \%\end{array}$

lowest involution, meaning that developments draw more heavily on technologies (inventions) outside the area of study. Electrolyte materials are made from either ceramic or glass. Electrolyte patents for both ceramic and glass have referenced patents for fabrication methods that have been applied in completely different fields (outside the patent study set). For example, many of General Electric's early electrolyte patents reference earlier work on ceramic fabrication methods applied to turbine blades.

\subsection{THE AGE OF THE SODIIIMYSSIJLFUR TECHNOLOGY RASE}

The patent indicator immediacy shows the age of the technology that is being developed and the pace of its progress. Immediacy is computed as the 
average age of the patent references for all patents filed in each year under study. In general, for technologies that refer to relatively older patents, we say that the pace of change is slower (or that the rate of obsolescence is less) than for technologies that reference very recent patents.

Figure 4.4 shows a time series plot of immediacy for the total patent set, references given to in-set patents, and references given to out-of-set patents. In-set and out-of-set references follow different patterns over time. Over most of the study period, the average age of in-set references has remained steady at about two years although it has risen to approximately four years recently. The average age of reference in the patent set for sodium/sulfur batteries is lower than that for most other emerging technologies studied with patent analysis (Campbell and Levine 1984). This low average age of in-set references implies that the technology is developing rapidly. Such a high rate of change suggests that organizations must continually invest $R \& D$ resources to keep up with the state-of-the-art.

TOTAL IN-SET OUT-OF-SET

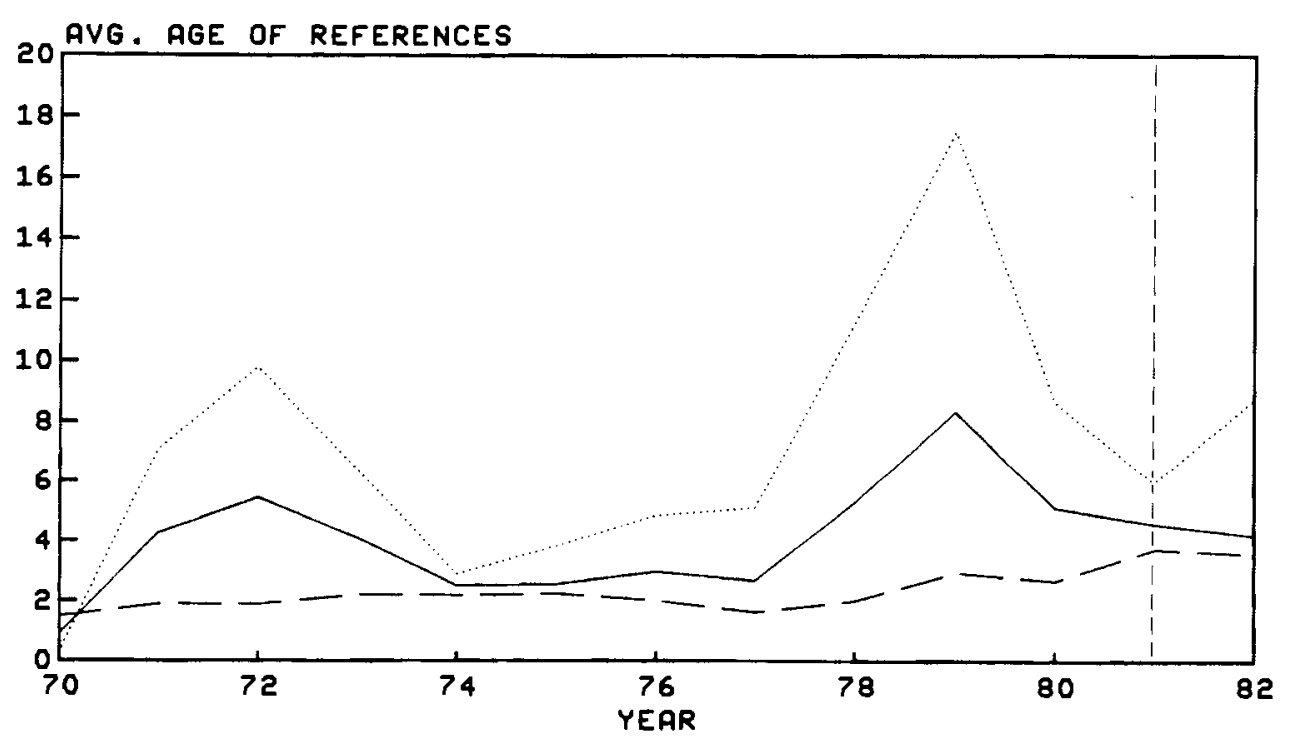

FIGURE 4.4. Immediacy: Average Age of References 
• 


\subsection{COMPARISON OF U.S. AND FOREIGN PATENT ACTIVITY}

Several of the broad trends in foreign and I.S. patent activity have been very similar. The growth in patent activity occurred in parallel, as did the activity peak and more recent decline in total output. Nevertheless, important differences between U.S. and foreign activity have emerged, e.g., important differences in the respective sodium/sulfur development strategies. In this section trends in patent activity and characteristics of the technology and its inventors are explored to highlight similarities and differences in the U.S. and foreign approach to technology development.

\subsection{TIME SERIES OF FOREIGN ANח U.S. ACTIVITY}

Figure 5.1 shows the level of overall sodium/sulfur patent activity and its breakdown by U.S. and foreign assignees. Refore 1970 almost all patents were held by 11.5 . firms with activity averaging about 5 patents per year. In

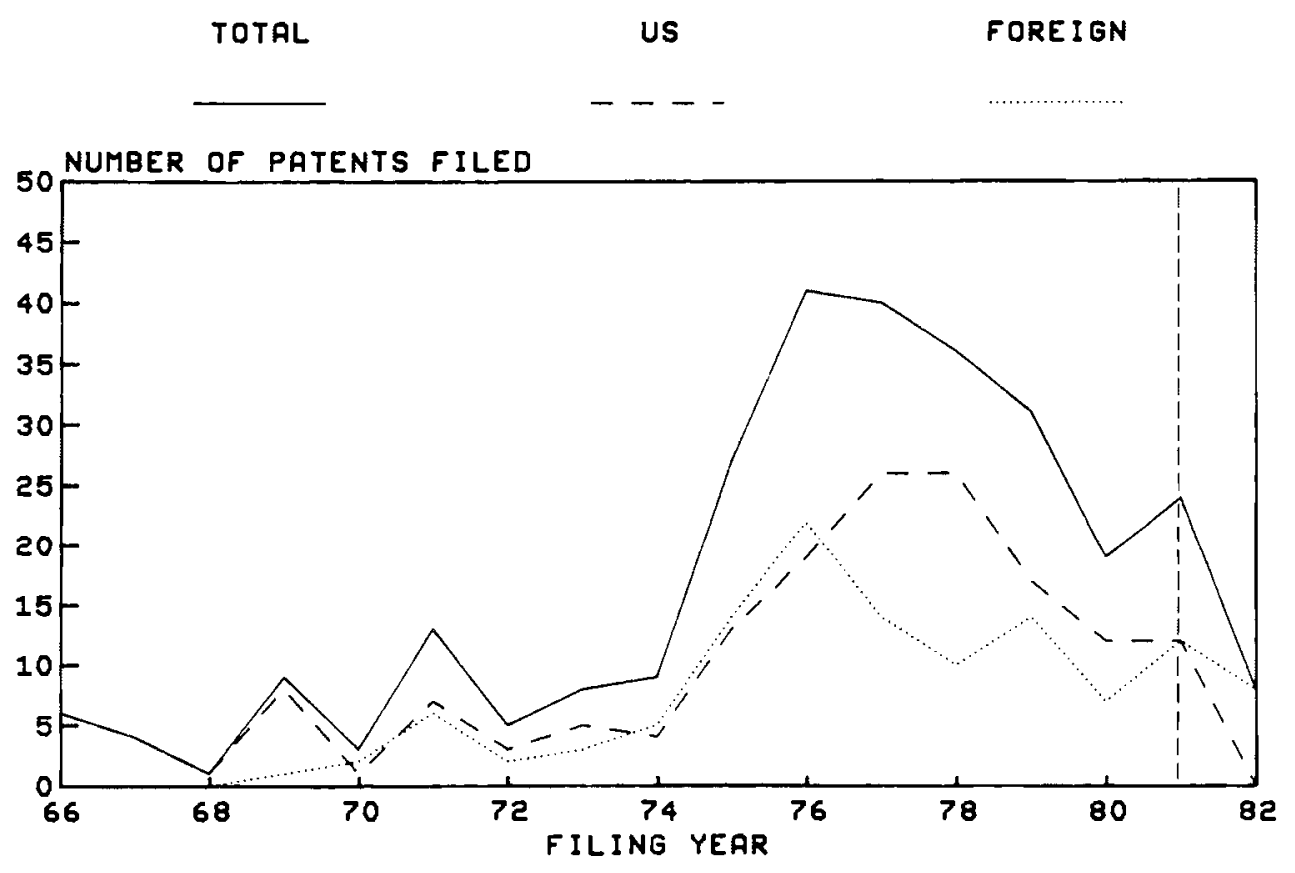

FIGURE 5.1. Activity: Foreign Versus United States 
1975 and 1976 patent filings increased sharply with foreign activity matching or slightly exceeding that of U.S. assignees. U.S. activity peaked with 26 patents in 1977 and 1978 before activity declined steadily. Foreign activity peaked in 1976, dropped somewhat in 1977, and has remained fairly constant since then at about 12 patents per year.

No U.S. patents filed in 1982 had issued hy April 1984, while eight foreign patents filed in 1982 had issued. It is too soon to tell if foreign activity will actually surpass U.S. activity when all filed patents have issued. (Statistics are not available on patents awaiting issue in the U.S. patent system.)

\subsection{ACTIVITY BY COUNTRY}

Only six countries hold sodium/sulfur hattery patents. Table 5.1 displays the patent filings by country in each of the three-year periods following the invention of the sodium/sulfur battery in 1965. In addition, both the total number of assignees and the number of new assignees active in each period are shown as a measure of the concentration of activity within each country.

The United States has dominated patent activity throughout the course of the technology's development. Through 1970, 11.S. assignees accounted for 21 of the 2.4 sodium/sulfur patents that had heen filed and subsequently issued. Japanese assignees accounted for the remaining three patents. The U.S. dominance of this technology declined in the last three years of the study period. While the data in this final period are incomplete because of the delay in patent issuance, the U.S. accounts for less than half of the total patents filed. Together West Germany and the United Kingdom account for 23 patents in this period, which nearly equals the U.S. total of 24 .

Table 5.1 also reveals important information regarding the number of assignees involved in sodium/sulfur development in each country. Typically, when an area shows commercial potential, as sodium/sulfur technology first did in the mid-1960s and later following the oil embargo, more firms become active 
TABLE 5.1. Patent and Assignee Activity by Country

\begin{tabular}{|c|c|c|c|c|c|c|c|}
\hline & Total & & & Issue & ear & & \\
\hline & $1965-82$ & $65-67$ & $68-70$ & $71-73$ & $74-76$ & $77-79$ & $80-82$ \\
\hline United States & & & & & & & \\
\hline Patents & 165 & 11 & 10 & 15 & 36 & 69 & 24 \\
\hline Active Assignees & & 3 & 4 & 7 & 13 & 15 & 9 \\
\hline New Assignees & 29 & 3 & 1 & 4 & 9 & 9 & 3 \\
\hline Japan & & & & & & & \\
\hline Patents & 17 & -- & 3 & 5 & 6 & 1 & 2 \\
\hline Active Assignees & & -- & 2 & 3 & 3 & 1 & 2 \\
\hline New Assignees & 7 & -- & 2 & 2 & 1 & 1 & 1 \\
\hline United Kingdom & & & & & & & \\
\hline Patents & 55 & -- & - & 4 & 23 & 16 & 12 \\
\hline Active Assignees & & - & -- & 2 & 5 & 2 & 2 \\
\hline New Assignees & 5 & -- & -- & 2 & 3 & -- & -- \\
\hline West Germany & & & & & & & \\
\hline Patents & 28 & -- & -- & -- & 3 & 14 & 11 \\
\hline Active Assignees & & -- & -- & -- & 2 & 3 & 2 \\
\hline New Assignees & 5 & -- & -- & -- & 2 & 2 & 1 \\
\hline France & & & & & & & \\
\hline Patents & 19 & -- & -- & 2 & 9 & 6 & 2 \\
\hline Active Assignees & & -- & -- & 1 & 2 & 4 & 1 \\
\hline New Assignees & 4 & -- & -- & 1 & 1 & 2 & -- \\
\hline
\end{tabular}

(South Africa holds one patent)

in its development. As development proceeds, the potential returns to inventive activity decline and some of the initial participants drop out. Thus, the development becomes more concentrated in fewer firms, particularly those that are well positioned to capture the commercial potential of the technology. Several measures of assignee concentration have been used in the past (see Campbell and Levine 1984). One measure of concentration can be obtained simply by taking a ratio of the number of patents to the number of assignees active in any given period. Dow Chemical, Ford Motor Company, General Flectric, and EPRI hold most of the U.S. patents (122 out of 165). Twenty-five firms and agencies hold the remaining 43 patents. This shows fairly concentrated activity among a few major developers. 
The United Kingdom and, more recently, West Germany have shown the most concentrated activity among foreign assignees. British activity has been very strong since 1974. Initially, British activity was shared among several organizations--the British Railways Board, The Electric Council, and the Secretary of State for Industry. From 1977 on, however, British activity has been concentrated in Chloride Silent Power, Ltd. The focus for technical development has shifted from the government and utility organizations to the private sector.

West Germany holds 28 patents, all of which were filed after 1974. Brown Boveri \& Cie holds 22 patents, which shows a high degree of concentration of effort within a single firm. No German patents are held by government agencies or utility research organizations. France holds 19 patents, 17 of which were filed after 1973. Compagnie Generale d'Electricite holds 13 patents, 11 of which were filed after 1975. As with the United Kingdom and West Germany, French activity is very highly concentrated within a single firm.

Japanese activity differs markedly from that of the other countries. While 17 patents are held, 8 were filed prior to 1974 and only 3 were filed after 1976. In the early stages, both Toyota and Yuasa Rattery Corp., Ltd., were active. NKG Spark Plug Company has been the most recent assignee. The Agency of Industrial Science and Technology was active (4 patents) between 1973 and 1976. Thus, Japanese activity has been less concentrated than that of the European countries and declined sharply in a period when the general level of activity was increasing or stable.

\subsection{AREAS OF TECHNOLOGY EMPHASIS}

An interesting difference in emphasis between II.S. and foreign patent positions can be seen in Table 3.1. Foreign patents appear to focus on electrodes and general design, whereas U.S. work emphasizes patents in electrolyte and seals/containers. Some indication as to the relative significance of the respective patent positions in these technology areas can be obtained by counting patent citations (Campbell and Nieves 1979). A patent is said to be "cited" if it is listed in the references of a later patent. Later patents usually represent improvements or extensions of the patents they are citing. 
Thus, highly cited patents are likely to be more technically significant than patents with low citation counts.

Table 5.2 displays data on U.S. and foreign citation counts by technology type; pre- and post-1974 performance is separated. When the number of patents receiving 10 or more citations is compared with patent activity, foreign patents appear to have an edge. Overall, the highly cited foreign patents number 11 out of 120 patents, while the same measures for U.S. patents are 10 out of 165. Citation of foreign patents is even more dramatic after 1973. In that case, 6 out of 106 foreign patents are highly cited and 2 out of 129 II.S. patents are highly cited.

Table 5.2 also indicates that the areas of dominance for highly cited patents are generally consistent with activity data. The II.S. has more highly cited patents in the electrolyte and seals/container areas; foreign patents are more highly cited in the electrode and general design categories. 
TABLE 5.2. Highly Cited Patents(a) Versus Overall Patent Activity by Technology Type(b)

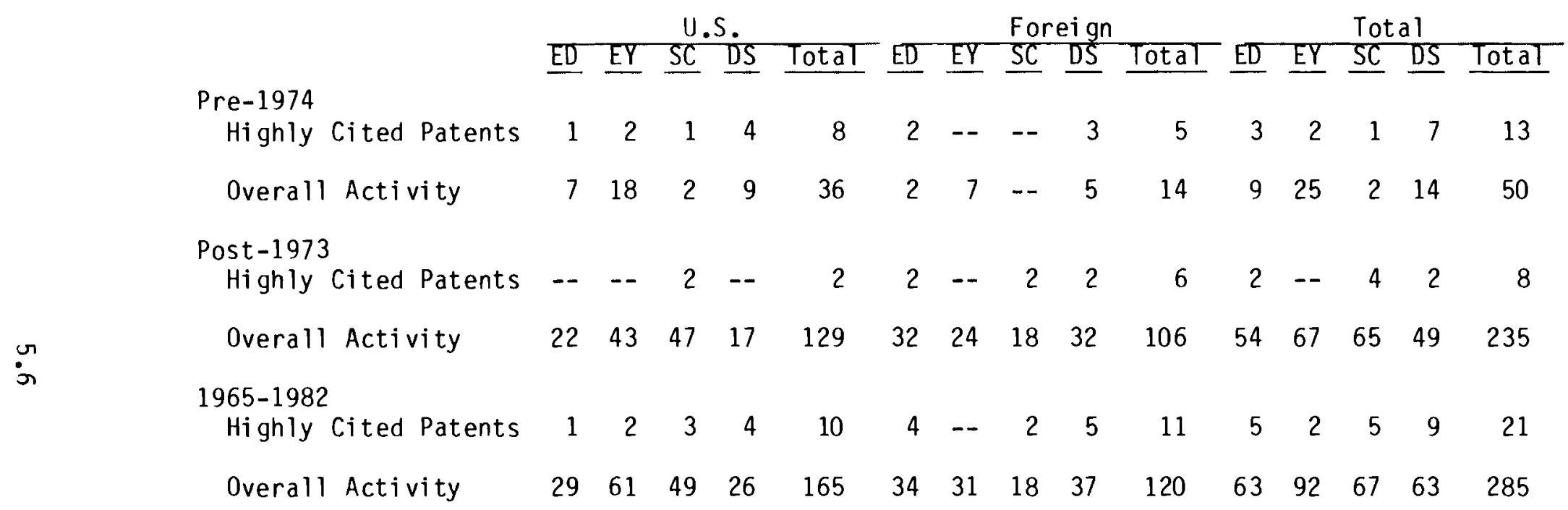

(a) Highly cited patents are defined as those with at least 10 citations.

(b) $E D=$ Electrodes

$E Y=E l e c t r o l y t e s$

$S C=$ Seals/containers

DS = General design. 


\subsection{COMPARISON OF II.S. AND FOREIGN ASSIGNEES}

Patent data provide insight into the level of inventive effort and the focus of that effort within the most active firms in a technology. This section summarizes patent data on the major U.S. and foreign assignees especially in terms of the level of inventive effort and the development linkages between patents for different assignees.

\subsection{OVERALL ASSIGNEE CHARACTERISTICS}

The 285 sodium/sulfur battery patents included in the patent set are distributed among 51 U.S. and foreign assignees. nomestic assignees began their patent activity in the mid-1960s. Japanese firms were the first foreign assignees to file for U.S. patents in the late 1960s; they were followed by Rritish and French firms in the early 1970 s and by West German assignees a few years later.

As a basis for the comparisons that follow, patent characteristics for the major assignees (those holding five or more patents) in the patent set are shown in Table 6.1. Some assignees with fewer patents are shown because of the significance of their patents or their participation in sodium/sulfur battery research.

\section{1 .1 Activity}

The simplest indication of an assignee's patent activity in sodium/sulfur battery technology is the total number of patents. According to this indicator, four American firms (Ford, General Electric(a), EPRI and Dow Chemical) and three foreign firms (England's Chloride Silent Power, the West German firm Brown Boveri \& Cie, and the Compagnie Generale d'Electricite of France) were the most active. The highest number of patents for a Japanese assignee (6) is held by Toyota.

(a) General Electric announced a termination of its sodium/sulfur battery development program after the date of the latest patents studied in this research. Accordingly, these results do not reflect that significant event. 
TABLE 6.1. Patent Characteristics of Major Assignees

\begin{tabular}{|c|c|c|c|c|c|c|c|c|c|c|c|c|c|}
\hline & $\begin{array}{l}\text { Total } \\
\text { Number of } \\
\text { Patents }\end{array}$ & $\begin{array}{c}\text { Total } \\
\text { Number of } \\
\text { Depreciated } \\
\text { Patents }\end{array}$ & $\begin{array}{l}\text { Number of } \\
\text { Inventors }\end{array}$ & $\begin{array}{l}\text { Number of } \\
\text { Patents, } \\
1974 \text { on } \\
\end{array}$ & $\begin{array}{l}\text { Nun } \\
\text { by } \\
\text { ED }\end{array}$ & $\begin{array}{l}\text { ber o } \\
\text { Techn } \\
\text { EY }\end{array}$ & $\begin{array}{r}\text { Pat } \\
\text { logy } \\
\text { SC }\end{array}$ & $\begin{array}{c}\text { ents } \\
\text { Type } \\
\text { DS }\end{array}$ & $\begin{array}{l}\text { Number of } \\
\text { In-set } \\
\text { Citations }\end{array}$ & $\begin{array}{l}\text { Number of } \\
\text { Self } \\
\text { Citations }\end{array}$ & $\begin{array}{c}\text { Percent } \\
\text { In-set } \\
\text { References }\end{array}$ & $\begin{array}{l}\text { Cites/ } \\
\text { Patent } \\
\text { (Total) } \\
\end{array}$ & $\begin{array}{l}\text { Cites/ } \\
\text { Patent } \\
\text { 1974 on }\end{array}$ \\
\hline Ford & 45 & 23.3 & 23 & 33 & 11 & 6 & 16 & 12 & 223 & 57 & 70.0 & 5.0 & 2.1 \\
\hline U-Utah/Ceramatee & 5 & 3.6 & 9 & 5 & 1 & 3 & 0 & 1 & 6 & 0 & 71.4 & 1.2 & 1.2 \\
\hline U.S. DOE & 3 & 2.7 & 5 & 3 & 0 & 3 & 0 & 0 & 1 & 0 & 70.4 & 0.3 & 0.3 \\
\hline Dow & 17 & 9.1 & 12 & 9 & 3 & 8 & 1 & 5 & 85 & 26 & 56.8 & 5.0 & 1.4 \\
\hline DuPont & 5 & 3.7 & 3 & 5 & 0 & 5 & 0 & 0 & 4 & 0 & 52.2 & 0.8 & 0.8 \\
\hline Corning & 5 & 4.5 & 2 & 5 & 0 & 1 & 2 & 2 & 0 & 0 & 87.5 & 0.0 & 0.0 \\
\hline General Electric & 38 & 22.7 & 24 & 27 & 4 & 17 & 15 & 2 & 97 & 24 & 41.4 & 2.6 & 2.1 \\
\hline EPRI & 22 & 16.0 & 10 & 22 & 7 & 0 & 12 & 3 & 36 & 14 & 67.6 & 1.6 & 1.6 \\
\hline Toyota & 6 & 2.5 & 5 & 2 & 2 & 4 & 0 & 0 & 32 & 2 & 44.1 & 5.3 & 3.5 \\
\hline $\begin{array}{l}\text { of Agency Ind. } \\
\mathrm{Scl} / \mathrm{Tech}\end{array}$ & 4 & 2.2 & 3 & 3 & 2 & 0 & 0 & 2 & 16 & 1 & 68.4 & 4.0 & 1.0 \\
\hline Yuasa Battery & 2 & 0.8 & 2 & 0 & 1 & 0 & 0 & 1 & 31 & 1 & 80.0 & 15.5 & 0.0 \\
\hline $\begin{array}{l}\text { Chloride sllent } \\
\text { Power }\end{array}$ & 31 & 23.7 & 26 & 31 & 10 & 7 & 8 & 6 & 75 & 20 & 68.2 & 2.4 & 2.4 \\
\hline Electric Council & 9 & 5.1 & 4 & 7 & 5 & 3 & 0 & 1 & 51 & 4 & 86.0 & 5.7 & 4.9 \\
\hline $\begin{array}{l}\text { Sec. / State } \\
\text { Industry }\end{array}$ & 8 & 4.6 & 10 & 8 & 4 & 1 & 0 & 3 & 35 & 2 & 82.9 & 4.4 & 4.4 \\
\hline $\begin{array}{l}\text { Britlsh Rall ways } \\
\text { Board }\end{array}$ & 5 & 2.6 & 3 & 3 & 1 & 1 & 1 & 2 & 24 & 0 & 66.7 & 4.8 & 7.0 \\
\hline $\begin{array}{l}\text { Brown Bover I } \\
\text { \& Clie }\end{array}$ & 23 & 18.8 & 21 & 23 & 7 & 1 & 7 & 8 & 15 & 6 & 60.5 & 0.7 & 0.7 \\
\hline $\begin{array}{l}\text { Generale } \\
\text { d'Electricite }\end{array}$ & 13 & 8.2 & 12 & 11 & 1 & 5 & 0 & 7 & 44 & 1 & 67.2 & 3.4 & 2.1 \\
\hline others & 44 & $=$ & $\bar{z}$ & 38 & 4 & $\underline{27}$ & 5 & $\underline{8}$ & 80 & $=$ & $=$ & 1.8 & $=$ \\
\hline Total & 285 & - & -- & 235 & 63 & 92 & 67 & 63 & 855 & - & 63.4 & 3.0 & - \\
\hline
\end{tabular}


The number of depreciated patents held by an assignee is a relative indication of how recently the assignee's set of patents was issued. This figure is calculated by summing the years remaining for all patents, then dividing the total by 17 (the term of a single patent). The result is the cumulative number of full patent terms remaining for all of an assignee's patents. When firms are ranked by the Total Number of Patents held, Ford and General Electric are the most active assignees, followed by Chloride Silent Power. But when assignees are ranked by the Number of Depreciated Patents held, Chloride Silent Power comes out ahead of Ford and General Electric. Chloride's patent activity has heen concentrated in the past ten years, so its patents have more cumulative years remaining than those of either ford or General Electric.

Another way of gauging how current an assignee's patents are is to list patent activity from 1974 onward. (Since it marked the beginning of major U.S. government funding, as well as the start of the sharp rise in overall patent activity, 1974 was chosen to divide patent activity.) From 1974 on Ford continued to be the most active assignee, but General Electric fell to third most active behind Chloride Silent Power.

\subsubsection{Number of Inventors}

Table 6.1 also shows the number of inventors listed in the patents held by each assignee. The overall number of inventors is a measure of the relative levels of effort made by assignees. Chloride Silent Power, General Electric, Ford, and Brown Boveri \& Cie have each listed more than twenty inventors on the patents they hold. One can also consider the ratio of the assignee's inventors to the number of patents it holds (not shown in Table 6.1). This ratio varies widely for assignees with fewer than ten patents. For the seven assignees with more than ten patents, American firms have a lower ratio of inventors to patents (ranging from 0.45 to 0.71 ) than do foreign assignees $(0.84$ to 0.92$)$.

\subsubsection{Areas of Emphasis}

The number of patents by technology type indicates the focus of an assignee's research. Some assignees (for instance, General Electric, EPRI, Dow Chemical and nupont) have concentrated their patenting in one or two of the 
four technology areas. Others (such as Ford, Chloride Silent Power, and Brown Boveri \& Cie) have patented in three or all four technology areas.

\subsubsection{Patent Citations}

The remaining measures in Table 6.1 deal with the citations received and references given by the assignees' patents. Data on citations provide a measure of the technical importance of the patents held by assignees. The number of in-set citations is the broadest indicator of the significance of an assignee's patents. Several factors influence the overall number of citations: the number of patents held by an assignee, the technical significance of the patents, and the age of the patents (older patents are likely to have received more citations than newer patents). The number of citations per patent and the number of citations per patent from 1974 on have also been calculated to control for the overall level of activity and the effect of citations on early basic patents.

The number of citations per patent for all patents shows the importance of Japanese inventions. Yuasa Battery and Toyota have high citation rates, although each holds relatively few patents. A ranking of assignees by the citations they have received per patent from 1974 on shows the importance of three British assignees holding relatively few patents (the British Railways Board, The Electric Council, and Britain's Secretary of State for Industry).

The high overall activity of some major assignees becomes less important when their citations are considered. Brown Boveri \& Cie's patents have been infrequently cited; Ceneral Electric shows a low number of citations per patent, and the number of citations per patent that Dow Chemical has received falls sharply when only its later patents are considered (from 5 citations per patent to 1.44 per patent for the newer patents).

\subsubsection{Patent References}

The final measure shown in Table 6.1 is the percent of in-set references, or involution (which is described in Section 4.2). Most major assignees are near the average of $63.4 \%$ for the patent set. A lower figure may indicate an attempt by the assignee to draw on technologies outside the patent set in solving research problems addressed by its patents. Of the four technology 
types, electrolyte research seems to have the largest potential for synthesis of other technologies. Also, assignees active early in the study period when there were few in-set patents to reference will tend to show a lower involution measure. General Electric and Toyota, two assignees with below-average involution figures, were both active fairly early and both hold patents in the electrolyte technology area.

\subsection{PATENT CITATION ANALYSIS}

The relationships between patent assignees in a technology can be shown by analyzing the citations and references passed between the major assignees in a patent set. The patterns of citations and references can illuminate several trends in the technology. Assignees who produce technically important patents will receive a large number of citations. Those assignees who draw on technology developed within the patent set will reference a greater proportion of in-set patents. Those assignees who attempt to draw on other technologies will reference a greater proportion of out-of-set patents.

The distinction between a citation and a reference is important in this discussion. A patent may make references to other patents; in turn, the same patent may receive citations from later patents. References to earlier patents are listed on the front page and in the text of a patent; the citations a patent accumulates after its issue can only be counted by looking at the references of a later patent. References are made to the most relevant prior art. By implication, patents receiving many citations are in some sense more significant than other patents because they are at the center of much follow-up activity.

In-set citations and references will be examined in two ways. First, the patterns of citations and references between assignees will be discussed with the help of an intercitation matrix of assignees. Then, individual patents that been highly cited will be covered.

\subsubsection{Intercitation Matrix}

Figure 6.1 shows an intercitation matrix for the major assignees in the sodium/sulfur battery patent set. In this matrix, the name of each assignee is 


\begin{tabular}{|c|c|c|c|c|c|c|c|c|c|c|c|c|c|c|c|c|c|c|c|}
\hline 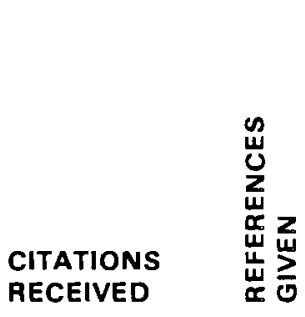 & $\begin{array}{l}\dot{8} \\
\dot{0} \\
\dot{0} \\
\dot{0} \\
0 \\
0 \\
\dot{0}\end{array}$ & 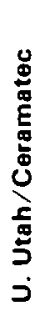 & 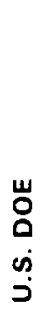 & 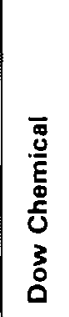 & 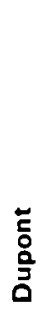 & 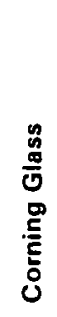 & 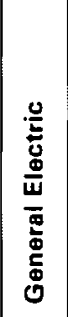 & $\begin{array}{l}\bar{\sigma} \\
\frac{\sigma}{D}\end{array}$ & $\frac{2}{0}$ & 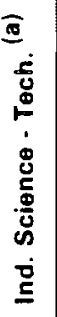 & 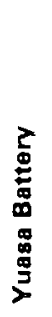 & 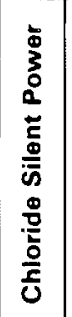 & 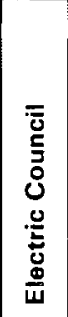 & 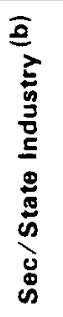 & 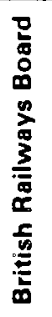 & 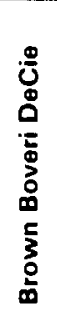 & 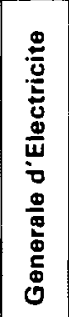 & 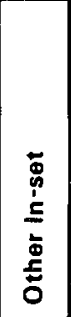 & $\begin{array}{l}\bar{\Phi} \\
\stackrel{0}{0}\end{array}$ \\
\hline Ford Motor Co. & 57 & 4 & 1 & 19 & 2 & & 22 & 6 & 9 & 7 & 4 & 12 & 15 & 10 & 6 & 14 & 18 & 17 & 223 \\
\hline U. Utah/Ceramatec & & & 2 & & & & 2 & & & & & & & & & & & 2 & 6 \\
\hline U.S. DOE & & & & & & & & & & & & & & & & & 1 & & 1 \\
\hline Dow Chemical & 3 & & & 26 & 8 & 14 & 2 & 4 & 1 & 2 & 1 & 4 & & 2 & 3 & 7 & 1 & 7 & 85 \\
\hline Dupont & & & & & & 1 & & & & & & & & & & & & 3 & 4 \\
\hline \multicolumn{20}{|l|}{ Corning Glass } \\
\hline General Electric & 18 & & 2 & & & & 24 & 16 & 1 & & 1 & 5 & 1 & 1 & 3 & 6 & 10 & 9 & 97 \\
\hline EPRI & 8 & & 1 & & & & 1 & 14 & & & & 4 & & & & 5 & 1 & 2 & 36 \\
\hline Toyota & 1 & & 4 & 1 & & & & 2 & 2 & 1 & & 5 & 5 & 1 & & 1 & 1 & 8 & 32 \\
\hline Ind. Science - Tech. ${ }^{(a)}$ & 2 & & & & & & 1 & & & 1 & & 3 & 2 & 2 & & 3 & 1 & 1 & 16 \\
\hline Yuasa Battery & 3 & & & & & & & 1 & 1 & & 1 & 5 & 5 & 4 & 2 & 3 & 1 & 3 & 31 \\
\hline Chloride Silent Power & 12 & 1 & 3 & & & 1 & 5 & 14 & & & & 20 & & & & 9 & & 10 & 75 \\
\hline Electric Council & 8 & 4 & 2 & 2 & & & 1 & 3 & & & & 17 & 4 & 4 & 1 & 2 & 2 & 1 & 51 \\
\hline $\mathrm{Sec} /$ State Industry $(\mathrm{b})$ & 5 & & & & & & & 7 & & & & 7 & 1 & 2 & 2 & 1 & 4 & 6 & 35 \\
\hline British Railways Board & 12 & & & & & & 2 & 2 & & & & 4 & 1 & & & 1 & & 2 & 24 \\
\hline Brown Boveri DeCie & 2 & & & & & & & & & & & 1 & & & & 6 & & 6 & 15 \\
\hline Generale d'Electricite & 7 & & & 1 & & & 11 & 2 & & 2 & 1 & 6 & 3 & & 1 & 4 & 1 & 5 & 44 \\
\hline Other In-set & 4 & 6 & 4 & 1 & 2 & 5 & 4 & 4 & 1 & & & 10 & & 3 & & 5 & & 31 & 78 \\
\hline Out-of-Set & 61 & 6 & 8 & 38 & 11 & 3 & 109 & 36 & 15 & 6 & 2 & 48 & 6 & 6 & 9 & 28 & 20 & 81 & 493 \\
\hline Total & 203 & 21 & 27 & 88 & 23 & 24 & 186 & 111 & 30 & 19 & 10 & 151 & 43 & 35 & 27 & 95 & 61 & 194 & 1348 \\
\hline
\end{tabular}

(a) Agency of Industrial Science and Technology. Japan

(b) Secretary of State for Industry, United Kingdom

FIGURE 6.1. Intercitation Matrix for Sodium-Sulfur Battery Technology 
listed both as a row heading and as a column heading because an assignee's patents may both give references and receive citations. To find out whose patents an assignee references, find the column heading naming that assignee and follow the column down. To find out who has cited a particular assignee's patents, locate the row heading naming the assignee and follow the row across. The diagonal crossing the matrix from upper left to lower right shows self-citations (references made by an assignee to its own patents).

The size of the numbers in Figure 6.1 makes the patterns of citations and references easy to discern; the largest indicate assignees whose patents have been cited most by others. In this patent set, we can see that Ford, Dow Chemical and General Flectric have been the most widely cited American assignees. EPRI, the other major American assignee, has been cited by fewer other assignees. In the United Kingdom, Chloride Silent Power has received 50\% more citations than The Electric Council, but these have been received from fewer assignees. Even though Chloride's patents are more highly cited, their patents have been less widely cited than those of The Flectric Council.

The rows in the intercitation matrix also show assignees whose patents have not been highly cited. Among American assignees, Corning's patents have not been cited at al1; the University of Utah/Ceramatec, U.S. Department of Energy, and Dupont have received only a few citations from other patents. The patents of all the Japanese and British assignees shown here have been cited by others. Also the difference between the Compagnie Generale d'Electricite and Brown Boveri \& Cie is noteworthy. Although the Compagnie Generale holds only 13 patents to Brown Boveri's 23, its patents have received three times as many citations as Brown Boveri's and have been cited by many more assignees.

The columns in Figure 6.1 indicate whose patents an assignee references in its own patents. As with the rows, assignees can be seen to reference the patents of many other assignees, or of only a few other assignees. Among American assignees, Ford has most widely referenced the patents of other firms, drawing particularly on the patents of General Electric, Chloride Silent Power and the British Railways Board. General Electric and EPRI have also referenced the patents of many other assignees, Dow Chemical less so. The U.S. Department of Energy's pattern of references is interesting in that, even though they hold 
only three patents, they have referenced the patents of seven other assignees, including Japanese and British assignees.

Foreign assignees also show some patterns of referencing diverse assignees. Japanese patents mostly reference those of Ford, Dow Chemical and General Electric. Patents held by the six European assignees in the matrix show a more marked attempt to synthesize other's results by referencing U.S. patents, Japanese patents, and those of the other European assignees (except, as noted earlier, Brown Boveri \& Cie patents).

When combined with what we have shown about overall patterns of activity, information on citations and references can begin to show how assignees draw on other's technology. Many of the citations received by the large American assignees in the patent set are references given to their early basic patents. These basic patents were referenced hy the Japanese in the late 1960s and early 1970s. The resulting Japanese patents, as well as the early American patents, were referenced by the European assignees when they began patenting a few years later. Patents assigned to the British organizations, to Japanese assignees, and to the Compagnie Generale d'Electricite are now being cited by newer American patents. This illustrates how one group of assignees can draw upon the work of others, with their advances, in turn, serving as further inspiration to those that began the work in the field.

\subsubsection{Highly Cited Patents}

The patterns of citations and references between assignees over time can be discerned by identifying individual patents receiving a high number of citations. A list of those patents in the set that have received ten or more in-set citations is shown in Table 6.2. Ten of the 21 patents in this list are held by U.S. assignees; the other eleven are held by foreign assignees.

The top portion of Table 6.2 is dominated by the early basic patents held by Ford and Dow Chemical. These basic patents have been cited many times since their issue (the older a patent is, the more citations it is likely to have received). Other Ford and Dow Chemical patents in the highly cited list are 
TABLE 6.2. Patents Receiving Ten or More Citations

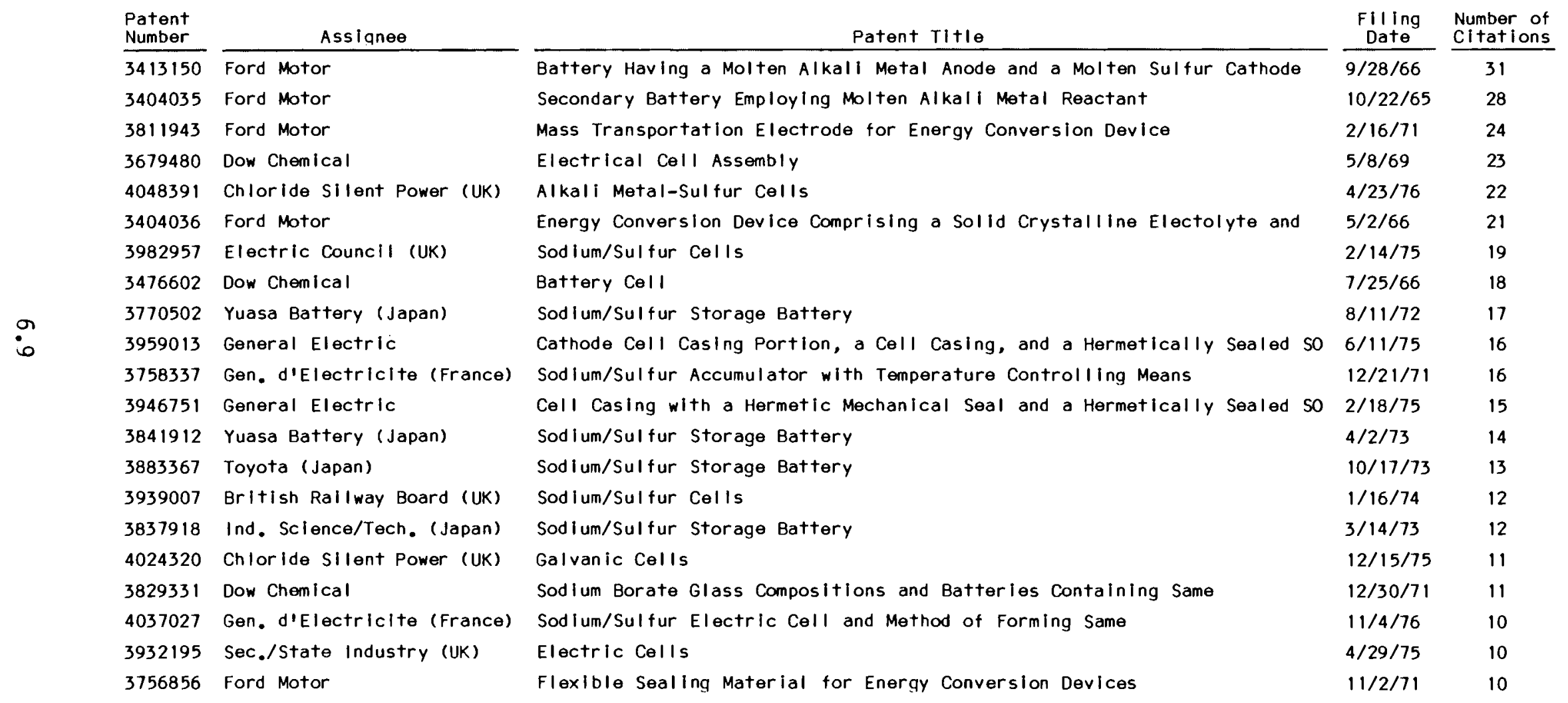


also earlier patents (all filed before 1972). Of American assignees, only General Electric holds newer highly cited patents. The two General Electric patents in Table 6.2 were filed in 1975.

Four of the 17 patents issued to Japanese assignees have received ten or more citations and are included in Table 6.2. These patents were all filed in the early 1970s, so have had less time to he cited than the Ford/Dow patents. Most notable are the two Yuasa Battery patents in the list. The two patents held by Yuasa have received 17 and 14 citations. Patents held by Toyota and the Agency of Industrial Science and Technology have also been highly cited.

Some of the patents in Table 6.2 held by British and French assignees are even newer than the Japanese patents. The highest foreign patent on the list, from Chloride Silent Power, received 22 citations in the eight years since it was filed. (The most highly cited patent overall received 31 citations, but those citations were received over the 18 years since the patent was filed in 1966.) Chloride Silent Power is joined in Table 6.2 by three other British assignees: The Electric Council, the British Railways Roard and the Secretary of State for Industry. The earliest British-assigned patent in this list was filed in 1971.

Dther foreign activity is represented in Table 6.2 by two patents held by the French firm Compagnie Generale d'Electricite, hoth filed in the 1970s. No Brown Boveri \& Cie patents have been highly cited, which is consistent with their patents receiving few citations overal1 (shown in Figure 6.1).

The patents in Table 6.2 were re-ordered chronologically and are shown in Table 6.3. This table reveals a more pronounced pattern of American patents at the top of the list (oldest), Japanese patents clustered in the middle and British assignees represented at the bottom of the list (most recent). The arrangement of highly cited patents over time parallels the patterns found in the intercitation matrix: early work by American assignees has been highly cited by Japanese and British assignees in their patents, which in turn are now being cited by newer American patents. 
TABLE 6.3. Patents Receiving Ten or More In-set Citations, Ranked Chronologically

\begin{tabular}{|c|c|c|c|}
\hline $\begin{array}{l}\text { Patent } \\
\text { Number }\end{array}$ & Assignee & $\begin{array}{c}\text { Filing } \\
\text { Date }\end{array}$ & $\begin{array}{l}\text { Number of } \\
\text { Citations } \\
\end{array}$ \\
\hline 3404035 & Ford Motor & $10 / 22 / 65$ & 28 \\
\hline 3404036 & Ford Motor & $5 / 2 / 66$ & 21 \\
\hline 3476602 & Dow Chemical & $7 / 25 / 66$ & 18 \\
\hline 3413150 & Ford Motor & $9 / 28 / 66$ & 31 \\
\hline 3679480 & Dow Chemical & $5 / 8 / 69$ & 23 \\
\hline 3811943 & Ford Motor & $2 / 16 / 71$ & 24 \\
\hline 3756856 & Ford Motor & $11 / 2 / 71$ & 10 \\
\hline 3758337 & Gen. d'Electricite (France) & $12 / 21 / 71$ & 16 \\
\hline 3829331 & Dow Chemical & $12 / 30 / 71$ & 11 \\
\hline 3770502 & Yuasa Rattery (Japan) & $8 / 11 / 72$ & 17 \\
\hline 3837918 & Ind. Science/Tech. (Japan) & $3 / 14 / 73$ & 12 \\
\hline 3841912 & Yuasa Battery (Japan) & $4 / 2 / 73$ & 14 \\
\hline 3883367 & Toyota (Japan) & $10 / 17 / 73$ & 13 \\
\hline 3939007 & British Railways Board (IJK) & $1 / 16 / 74$ & 12 \\
\hline 3982957 & Electric Council (UK) & $2 / 14 / 75$ & 19 \\
\hline 3946751 & General Electric & $2 / 18 / 75$ & 15 \\
\hline 3932195 & Sec./State Industry (UK) & $4 / 29 / 75$ & 10 \\
\hline 3959013 & General Electric & $6 / 11 / 75$ & 16 \\
\hline 4024320 & Chloride Silent Power (UK) & $12 / 15 / 75$ & 11 \\
\hline 4048391 & Chloride Silent Power (UK) & $4 / 23 / 76$ & 22 \\
\hline 4037027 & Gen. d'Electricite (France) & $11 / 4 / 76$ & 10 \\
\hline
\end{tabular}

\subsection{PROFILES OF MAJOR ASSIGNEES}

The major domestic organizations patenting in the sodium/sulfur battery technology can be divided into two groups. Research undertaken by the first group, which includes the Department of Energy, Ford Motor Company, and Dow Chemical Company, was supported by the National Science Foundation and the Department of Energy. The other major domestic group contains the Electric Power Research Institute (EPRI) and General Electric, which has been supported by EPRI in recent years. 


\subsubsection{Department of Energy/Ford/Dow Chemical}

Since 1973 the U.S. government has made a significant investment in sodium/sulfur battery research. The National Science Foundation provided early funding; in 1976 the program was transferred to ERDA/DOE.

Ford, the most active assignee in the patents under study, has benefited from government funding. Their independent work in the area resulted in 12 patents filed between 1965 and 1971; these patents concentrated in the electrolyte and design technology areas. Five of these patents are highly cited, basic patents. Early government-funded work (1975-76) concentrated in electrodes; more recently, Ford has been patenting in the seals/containers and general design areas. However, the patents resulting from their later, government-funded research have not been highly cited by others.

The University of Utah and its spin-off firm Ceramatec have received funding from DOE through Ford for sodium/sulfur research and have received five patents. They began filing patents in 1975 and have done most of their work in electrolytes. They hold no highly cited patents.

Dow Chemical has also participated in the NSF/DOE research program. Dow is a major assignee, holding seventeen patents filed between 1966 and 1978 . While they have patented in all four technology areas, their work is concentrated in glass electrolytes. Three of Dow's patents have been highly cited. Like Ford, Dow's highly cited patents were issued early in the study period, with patents resulting from government-funded research not being highly cited.

Dupont and Corning Glassworks each hold five patents that heavily reference Dow patents. Dupont patented in the electrolyte area and only patented in the late 1970s. Corning, a recent entry in the field, does not seem to have concentrated in any one technology area. None of the Dupont or Corning patents have been cited much, at least partially because of their newness.

\subsubsection{General Electric/Electric Power Research Institute}

The second group of major U.S. patent assignees includes General Electric and the Electric Power Research Institute (EPRI). EPRI has funded some of General Electric's later work in the area. 
General Electric is the second most active assignee in the study, claiming 38 patents filed between 1967 and 1981. They have filed patents in all four technology areas, but have concentrated their efforts in electrolytes and containers. General Electric's level of activity has been fairly steady. Two of their container patents, both issued in 1976, have been highly cited, however, their earlier work has not been cited often, their later patents even less.

EPRI did not file its first patent until 1976 and has had 22 patents issued since then. They filed several patents a year through 1979. If they have filed any patent applications more recently than 1980 , the patents have not yet been issued. EPRI patents are concentrated in containers and electrodes. None of their patents have been highly cited (a 1978 container patent is the most highly cited with eight citations). Again, this is partly because their patents are relatively new.

\subsubsection{Dther IJ.S. Assignees}

In addition to the eight assignees discussed above, 21 other U.S. assignees are listed in the sodium/sulfur patent set. None of these firms or organizations have been assigned more than three patents. There are a few interesting points about these less active assignees. For instance, several petroleum companies (Exxon, She11, Phillips) have made brief efforts in the area; each holds only one patent. The II.S. Army has also done some sodium/ sulfur research and has funded Westinghouse Electric Corporation for two of Westinghouse's three patents, all of which have issued since 1980. Among research and academic organizations, MIT holds two patents, the Cornell Research Foundation and Bell Labs each hold one patent.

\subsubsection{Japanese Assignees}

Japanese patenting in sodium/sulfur batteries is mostly limited to the early and mid-1970s. Several Japanese assignees received patents during these years. While research in the technology continues, recent funding by the Japanese government has not led to new II.S. patent activity by Japanese assignees. Several highly cited patents are included in those held by Japanese assignees. For instance, Toyota holds six patents, which were filed from 1969 through 1975; one of their electrode patents, which was issued in 1975, has 
al ready received 13 citations. Yuasa Battery holds only two patents, but they have received 17 and 14 citations since their issue (1973 and 1974). In general, the Japanese patents cite earlier Ford patents; their patents, in turn, are being cited heavily by British assignees' patents.

Other Japanese assignees are the Agency of Industrial Science and Technology (associated with MITI), NKG Spark Plug, Nichicon Capacitor, Seiko and Hitachi.

\subsubsection{British Assignees}

British patenting in sodium/sulfur batteries began in 1971 , rose sharply in 1975, and has remained fairly steady since then. Research done by British assignees is divided into all technology areas--none seem to have concentrated in only one area.

The earliest patented work was done by The Electric Council (nine filings from 1971 through 1977) and the British Railways Board (five filings, 1971 through 1976). In 1975 and 1976 Britain's Secretary of State for Industry filed for eight patents, all of which were issued. Each of these assignees holds one patent receiving ten or more citations (all issued in 1976).

Recent Rritish patenting has been done almost exclusively by Chloride silent Power, Ltd., the third most active assignee in the patent set with 31 sodium/sulfur patents listed in its name. Chloride silent did not file any patents before 1975 , but has been patenting heavily since then, as activity by the other British assignees has fallen off. Chloride Silent's patents are in all technology areas; their first electrode patent, issued in 1977, has already received 22 citations.

Early British work cites the basic Ford and General Electric patents, as well as Japanese patents. Chloride Silent's patents cite earlier British patents. In turn, Chloride silent is now being cited by Ford and FPRI, among others. 


\subsubsection{Brown Boveri \& Cie (West Germany)}

An assignee whose pattern of activity is similar to that of Chloride Silent Power is West Germany's(a) Brown Boveri \& Cie, A.G. Brown Boveri filed its first patent application in 1975, and has been issued 23 patents since then (fourth largest in the patent set). Their earlier work was concentrated in the electrode technology area; more recently, they have been patenting in seals/ containers and general design technologies. Brown Boveri patents cite Ford and chloride silent Power patents. Their own patents, however, have been infrequently cited, in marked contrast to those of the Japanese and British assignees.

\subsubsection{Compagnie Generale d'Electricite (France)}

The last major assignee is the Compagnie Generale d'Electricite of France. This firm has received 13 patents between 1971 and 1981. Seven of these patents were filed in 1976; their activity has been low since then. Their 1976 burst of filings was concentrated in the design area; recently, they have been filing electrolyte patents. They primarily cite Ford and General Electric patents, including both the basic and newer patents. Two of the Compagnie Generale's design patents have received 16 and 10 citations. Their patents have been most cited by General Electric, Ford and Chloride Silent Power.

(a) Although incorporated in Switzerland, Brown Boveri was considered to be a West German firm for this study since all sodium/sulfur technology development occurred at a West German facility and was substantially funded by the West German government. 
Campbe 11, R. S., and L. O. Levine. 1984. Technology Indicators Based on Patent Data, Phase II Report: Development and Application of Indicators. Prepared for the National Science Foundation under NSF Grant PRA 78-20321, National Technical Information Service, Springfield, Virginia.

Campbel1, R. S. 1983. "Patent Trends as a Technological Forecasting Tool." World Patent Information. 5(3):137-143.

Campbe11, R. S., and A. L. Nieves. 1979. Technology Indicators Rased on Patent Data: The Case of the Catalytic Converters, Phase I Report: Design and Demonstration. Prepared for the National Science Foundation under NSF Grant PRA 78-20321, PB 82154150, National Technical Information Service, Springfield, Virginia. 
Ashton, W. B., L. O. Levine, and R. S. Campbell. 1985. Patent Trend Analysis: Tracking Technology Change for Rusiness Planning. BTIP Report No. 44. Battelle Technical Inputs to Planning. Battelle Memorial Institute, Columbus, Ohio.

Campbell, R. S. 1983. "Patenting the Future: A New Way to Forecast Changing Technology." The Futurist, December 1983, pp. 62-67.

Campbell, R. S. and L. O. Levine. 1983. "Patent Analysis: Tracking Technology Trends" Rattelle Today. April 1983, No. 32, Battelle Memorial Institute, Columbus, Ohio.

Carpenter, M. P., F. Narin and P. Woolf. 1981. "Citation Rates to Technologically Important Patents." World Patent Information. 3(4):161-163.

farrett-Price, B. A., et a1. 1984. Industrial Fouling: Problem Characterization, Economic Assessment, and Review of Prevention, Mitigation, and Accommodation Techniques. PNL-4883, Pacific Northwest Laboratory, Richland, Washington.

Griliches, Z. (ed). 1984. R\&D, Patents and Productivity. The University of Chicago Press. Chicago, ITTinois.

Levine, L. 0. 1984. Summary of Trends in Photovoltaic Patent Activity. PNL5150, Pacific Northwest Laboratory, Richland, Washington.

Levine, L. 0., W. B. Ashton, and R. S. Campbe11. 1984. A Preliminary Analysis of Patent Trends for Magnetic Fusion Technology. PNL-4932, Pacific Northwest Laboratory, Richland, Washington.

Levine, L. 0., J. D. Kaschmitter, and A. L. Slavich. 1984. Patent Indicator Analys is Computer Software: User's Fuide. Battelle, Pacific Northwest Laboratories, Richland, Washington.

Mansfield, F., et al. 1982. "Patents, Imitation Costs, and the Rate of Innovation." In Technology Transfer, Productivity and Economic Policy, pp. 132-153. W. W. Norton and Co., New York, New York.

Martino, J. P. 1983. Technological Forecasting for Decisionmaking. 2nd ed. American Elsevier Publishing Co., New York, New York.

Pavitt, K. 1983. Patent Statistics as Indicators of Innovative Activities: Possibilities and Problems. Paper presented at the annual meeting of the American Association of the Advancement of Science, May 30, 1983, Detroit, Michigan.

Scherer, F. M. 1983. "The Propensity to Patent." International Journal of Industrial Organization. 1(1983):107-128. 
Slavich, A. L. and J. D. Kaschmitter. 1984. Patent Indicator Analysis Computer Software: Programmer's Guide. Rattelle, Pacific Northwest Laboratories, Richland, Washington.

U.S. Patent Office. 1972. General Information Concerning Patents. U.S. Government Printing Office, Washington, D.C.

U.S. Patent Office. 1981. Manual of Classification. Revision No. 6 - April 1981. U.S. Government Printing Office, Washington, D.C.

U.S. Patent and Trademark Office, Office of Technology Assessment and Forecast. 1981. Technology Assessment and Forecast: Tenth Report. U.S. Government Printing Office, Washington, D.C.

Utterback, J. M., and E. H. Burack. 1975. "Identification of Technological Threats and Opportunities by Firms." Technological Forecasting and Social Change. $8(1), 7-21$.

Wiseman, P. 1983. "Patenting and Inventive Activity on Synthetic Fibre Intermediates." Research Policy. 12(1983):329-339. 


\section{APPENDIX A}

SODIUM/SULFUR PATENT ANALYSIS DATA 
TABLE A.1. Assignee Patent Activity Over Time

\begin{tabular}{|c|c|c|c|c|c|c|c|c|c|}
\hline \multirow{2}{*}{$\begin{array}{l}\text { Filing } \\
\text { Year }\end{array}$} & \multirow{2}{*}{$\begin{array}{c}\text { Number of } \\
\text { Patents }\end{array}$} & \multicolumn{4}{|c|}{ Assignee Sector $(a)$} & \multicolumn{4}{|c|}{ Technology Type ${ }^{(\mathrm{b})}$} \\
\hline & & GV & $G C$ & $0 D$ & FO & ED & $E Y$ & SC & DS \\
\hline 65 & 1 & 0 & 1 & 0 & 0 & 0 & 0 & 0 & 1 \\
\hline 66 & 6 & 0 & 6 & 0 & 0 & 0 & 4 & 0 & 2 \\
\hline 67 & 4 & 0 & 3 & 1 & 0 & 0 & 0 & 0 & 4 \\
\hline 68 & 1 & 1 & 0 & 0 & 0 & 0 & 0 & 0 & 1 \\
\hline 69 & 9 & 0 & 3 & 5 & 1 & 2 & 6 & 0 & 1 \\
\hline 70 & 3 & 0 & 1 & 0 & 2 & 1 & 2 & 0 & 0 \\
\hline 71 & 13 & 0 & 4 & 3 & 6 & 3 & 6 & 1 & 3 \\
\hline 72 & 5 & 0 & 2 & 1 & 2 & 2 & 3 & 0 & 0 \\
\hline 73 & 8 & 0 & 1 & 4 & 3 & 1 & 4 & 1 & 2 \\
\hline 74 & 9 & 1 & $n$ & 3 & 5 & 2 & 3 & 3 & 1 \\
\hline 75 & 27 & 8 & 0 & 5 & 14 & 10 & 6 & 4 & 7 \\
\hline 76 & 41 & 4 & 4 & 11 & 22 & 12 & 15 & 5 & 9 \\
\hline 77 & 40 & 12 & 2 & 12 & 14 & 12 & 7 & 15 & 6 \\
\hline 78 & 36 & 5 & 3 & 18 & 10 & 7 & 8 & 17 & 4 \\
\hline 79 & 31 & 5 & 4 & 8 & 14 & 6 & 8 & 8 & 9 \\
\hline 80 & 19 & 3 & 0 & 9 & 7 & 1 & 7 & 7 & 4 \\
\hline 81 (c) & 24 & 3 & 2 & 7 & 12 & 3 & 11 & 4 & 6 \\
\hline $82^{(c)}$ & 8 & 0 & 0 & 0 & 8 & 1 & 2 & 2 & 3 \\
\hline TOTAL & & 42 & 36 & 87 & 120 & 63 & 92 & 67 & 63 \\
\hline PER & CENT & $(0.15)$ & $(0.13)$ & $(0.31)$ & $(0.42)$ & $(0.22)$ & $(0.32)$ & $(0.24)$ & $(0.22)$ \\
\hline
\end{tabular}

\footnotetext{
(a) $\mathrm{GV}=$ Government-held or sponsored.

$G C=$ Government Contractor (e.g. Ford, IJtah, Dow, etc.)

$O D=0$ ther IJ.S. assignee (GE, EPRI, Corning, etc.)

$\mathrm{FO}=$ Foreign assignee

(b) $E D=$ Electrode design

$E Y=$ Electrolyte/Separator

$S C=$ Seal/Container

$\mathrm{nS}=$ General design

(c) Probably understates true activity since some patents filed have yet to issue. We have all patents issuing through 4/1/84.
} 
TABLE A.2. U.S. Versus Foreign Activity by Technology Type Over Time

\begin{tabular}{|c|c|c|c|c|c|c|c|c|c|c|c|c|c|c|c|}
\hline \multirow{2}{*}{$\begin{array}{l}\text { Filing } \\
\text { Year }\end{array}$} & \multicolumn{3}{|c|}{ Electrodes } & \multicolumn{3}{|c|}{ Electrolytes } & \multicolumn{3}{|c|}{$\begin{array}{c}\text { Seals/ } \\
\text { Containers } \\
\end{array}$} & \multicolumn{3}{|c|}{$\begin{array}{r}\text { General } \\
\text { Design } \\
\end{array}$} & \multicolumn{3}{|c|}{ Tota 1} \\
\hline & US & FN & Total & US & FN & Total & USS & FN & Total & $\overline{U S}$ & $\overline{F N}$ & $\overline{\text { Total }}$ & $\overline{\mathrm{US}}$ & $\overline{F N}$ & $\overline{\text { Total }}$ \\
\hline 1965 & -- & -- & -- & -- & -- & -- & -- & -- & -- & 1 & -- & 1 & 1 & -- & 1 \\
\hline 1966 & -- & -- & -- & 4 & -- & 4 & -- & -- & -- & 2 & -- & 2 & 6 & -- & 6 \\
\hline 1967 & -- & -- & -- & -- & -- & -- & -- & -- & -- & 4 & - & 4 & 4 & -- & 4 \\
\hline 1968 & -- & -- & -- & -- & -- & -- & -- & -- & -- & 1 & -- & 1 & 1 & -- & 1 \\
\hline 1969 & 2 & -- & 2 & 5 & 1 & 6 & -- & -- & -- & 1 & - & 1 & 8 & 1 & 9 \\
\hline 1970 & 1 & -- & 1 & -- & 2 & 2 & -- & -- & -- & -- & -- & -- & 1 & 2 & 3 \\
\hline 1971 & 3 & -- & 3 & 3 & 3 & 6 & 1 & -- & 1 & -- & 3 & 3 & 7 & 6 & 13 \\
\hline 1972 & 1 & 1 & 2 & 2 & 1 & 3 & -- & -- & -- & -- & -- & -- & 3 & 2 & 5 \\
\hline 1973 & -- & 1 & 1 & 4 & -- & 4 & 1 & -- & 1 & -- & 2 & 2 & 5 & 3 & 8 \\
\hline 1974 & -- & 2 & 2 & 2 & 1 & 3 & 2 & 1 & 3 & -- & 1 & 1 & 4 & 5 & 9 \\
\hline 1975 & 5 & 5 & 10 & 4 & 2 & 6 & 2 & 2 & 4 & 2 & 5 & 7 & 13 & 14 & 27 \\
\hline 1976 & 4 & 8 & 12 & 9 & 6 & 15 & 4 & 1 & 5 & 2 & 7 & 9 & 19 & 22 & 41 \\
\hline 1977 & 5 & 7 & 12 & 4 & 3 & 7 & 13 & 2 & 15 & 4 & 2 & 6 & 26 & 14 & 40 \\
\hline 1978 & 4 & 3 & 7 & 7 & 1 & 8 & 13 & 4 & 17 & 2 & 2 & 4 & 26 & 10 & 36 \\
\hline 1979 & 2 & 4 & 6 & 5 & 3 & 8 & 6 & 2 & 8 & 4 & 5 & 9 & 17 & 14 & 31 \\
\hline 1980 & 1 & -- & 1 & 4 & 3 & 7 & 5 & 2 & 7 & 2 & 2 & 4 & 12 & 7 & 19 \\
\hline 1981 & 1 & 2 & 3 & 8 & 3 & 11 & 2 & 2 & 4 & 1 & 5 & 6 & 12 & 12 & 24 \\
\hline 1982 & $=$ & 1 & 1 & - & 2 & 2 & $=$ & 2 & 2 & -- & 3 & 3 & -- & 8 & 8 \\
\hline Total & 29 & 34 & 63 & 61 & 31 & 92 & 49 & 18 & 67 & 26 & 37 & 63 & 165 & 120 & 285 \\
\hline
\end{tabular}


TABLE A.3. Patent Characteristics Over Time by Technology Type

\begin{tabular}{|c|c|c|c|c|c|c|c|c|c|c|c|c|c|c|c|c|}
\hline \multirow{2}{*}{$\begin{array}{l}\text { Filing } \\
\text { Years } \\
\end{array}$} & \multicolumn{4}{|c|}{$\begin{array}{l}\text { Number of } \\
\text { Patents }\end{array}$} & \multicolumn{4}{|c|}{$\begin{array}{l}\text { Distinct } \\
\text { Inventors }\end{array}$} & \multicolumn{4}{|c|}{$\begin{array}{c}\text { Total } \\
\text { Inventors }\end{array}$} & \multicolumn{4}{|c|}{$\begin{array}{c}\text { Distinct } \\
\text { Organizations }\end{array}$} \\
\hline & ED & $E Y$ & $S C$ & $\overline{D S}$ & $\overline{E D}$ & $E Y$ & $S C$ & $D S$ & $\overline{E D}$ & EY & $S C$ & $\mathrm{nS}$ & ED & $E Y$ & $S C$ & $\mathrm{DS}$ \\
\hline 1965 & 0 & 0 & 0 & 1 & 0 & 0 & 0 & 2 & 0 & 0 & 0 & 2 & 0 & 0 & 0 & 1 \\
\hline 1966 & 0 & 4 & 0 & 2 & 0 & 4 & 0 & 2 & 0 & 6 & 0 & 4 & 0 & 2 & 0 & 1 \\
\hline 1967 & 0 & 0 & 0 & 4 & 0 & 0 & 0 & 4 & 0 & 0 & 0 & 4 & 0 & 0 & 0 & 2 \\
\hline 1968 & 0 & 0 & 0 & 1 & 0 & 0 & 0 & 1 & 0 & 0 & 0 & 1 & 0 & 0 & 0 & 1 \\
\hline 1969 & 2 & 6 & 0 & 1 & 1 & 10 & 0 & 3 & 2 & 15 & 0 & 3 & 1 & 4 & 0 & 1 \\
\hline 1970 & 1 & 2 & 0 & 0 & 2 & 3 & 0 & 0 & 2 & 3 & 0 & 0 & 1 & 2 & 0 & 0 \\
\hline 1971 & 3 & 6 & 1 & 3 & 5 & 9 & 1 & 6 & 5 & 9 & 1 & 6 & 3 & 6 & 1 & 2 \\
\hline 1972 & 2 & 3 & 0 & 0 & 3 & 4 & 0 & 0 & 3 & 4 & 0 & 0 & 2 & 3 & 0 & 0 \\
\hline 1973 & 1 & 4 & 1 & 2 & 1 & 4 & 1 & 2 & 1 & 6 & 1 & 2 & 1 & 2 & 1 & 2 \\
\hline 1974 & 2 & 3 & 3 & 1 & 4 & 8 & 5 & 3 & 4 & 8 & 5 & 3 & 2 & 3 & 2 & 1 \\
\hline 1975 & 10 & 6 & 4 & 7 & 16 & 16 & 9 & 10 & 22 & 16 & 10 & 13 & 4 & 5 & 3 & 3 \\
\hline 1976 & 12 & 15 & 5 & 9 & 19 & 22 & 6 & 11 & 26 & 27 & 7 & 19 & 8 & 14 & 3 & 5 \\
\hline 1977 & 12 & 7 & 15 & 6 & 14 & 11 & 16 & 9 & 23 & 14 & 25 & 9 & 7 & 5 & 5 & 4 \\
\hline 1978 & 7 & 8 & 17 & 4 & 11 & 9 & 26 & 7 & 12 & 10 & 38 & 7 & 5 & 7 & 7 & 4 \\
\hline 1979 & 6 & 8 & 8 & 9 & 8 & 15 & 12 & 13 & 10 & 15 & 12 & 16 & 3 & 6 & 6 & 6 \\
\hline 1980 & 1 & 7 & 7 & 4 & 2 & 11 & 15 & 5 & 2 & 14 & 16 & 5 & 1 & 5 & 5 & 4 \\
\hline 1981 & 3 & 11 & 4 & 6 & 4 & 15 & 7 & 8 & 4 & 17 & 8 & 9 & 2 & 8 & 3 & 5 \\
\hline 1982 & 1 & 2 & 2 & 3 & 3 & 4 & 6 & 3 & 3 & 4 & 6 & 4 & 1 & 2 & 1 & 1 \\
\hline TOTAL & 63 & 92 & 67 & 63 & 93 & 145 & 104 & 89 & 119 & 168 & 129 & 107 & 41 & 74 & 37 & 43 \\
\hline
\end{tabular}


TABLE A.4. Involution Over Time

\begin{tabular}{|c|c|c|c|c|c|}
\hline $\begin{array}{l}\text { Filing } \\
\text { Year } \\
\end{array}$ & $\begin{array}{c}\text { Number of } \\
\text { Patents } \\
\end{array}$ & $\begin{array}{r}\text { Number of } \\
\text { References }\end{array}$ & $\begin{array}{c}\text { Number of } \\
\text { In-set } \\
\text { References }\end{array}$ & $\begin{array}{l}\text { Number of } \\
\text { Out-of-Set } \\
\text { References }\end{array}$ & $\begin{array}{l}\text { Involution: } \\
\text { Percentage } \\
\text { of In-set } \\
\text { References } \\
\end{array}$ \\
\hline 1965 & 1 & 3 & - & 3 & - \\
\hline 1966 & 6 & 15 & 3 & 12 & 20.0 \\
\hline 1967 & 4 & 16 & 8 & 8 & 50.0 \\
\hline 1968 & 1 & 2 & - & 2 & - \\
\hline 1969 & 9 & 34 & 14 & $2 n$ & $41 . ?$ \\
\hline 1970 & 3 & 8 & 4 & 4 & 50.0 \\
\hline 1971 & 13 & 79 & 43 & 36 & 54.4 \\
\hline 1972 & 5 & 20 & 11 & 9 & 55.0 \\
\hline 1973 & 8 & 40 & 22 & 18 & 55.0 \\
\hline 1974 & 9 & 44 & 24 & 20 & 54.5 \\
\hline 1975 & 27 & 116 & 92 & 24 & 79.3 \\
\hline 1976 & 41 & 144 & 95 & 49 & 66.0 \\
\hline 1977 & $4 n$ & 159 & 111 & 48 & 69.8 \\
\hline 1978 & 36 & 243 & 157 & 86 & 64.6 \\
\hline 1979 & 31 & 183 & 115 & 68 & 62.8 \\
\hline 1980 & 19 & 98 & 58 & 40 & 59.2 \\
\hline 1981 & 24 & 111 & 69 & 42 & $62 . ?$ \\
\hline 1982 & 8 & 33 & 29 & 4 & 87.9 \\
\hline Total & 285 & 1348 & 855 & 493 & 63.4 \\
\hline
\end{tabular}


TABLE A.5. Immediacy Over Time

\begin{tabular}{|c|c|c|c|}
\hline \multirow[b]{2}{*}{$\begin{array}{l}\text { Filing } \\
\text { Year }\end{array}$} & \multicolumn{3}{|c|}{ Mean Age of References (in years) } \\
\hline & $\begin{array}{c}\text { A11 } \\
\text { References }\end{array}$ & $\begin{array}{c}\text { In-Set } \\
\text { References }\end{array}$ & $\begin{array}{l}\text { Out-of-Set } \\
\text { References }\end{array}$ \\
\hline 1965 & 15.7 & - & 15.7 \\
\hline 1966 & 3.9 & 0 & 4.8 \\
\hline 1967 & 6.1 & 0 & 12.1 \\
\hline 1968 & 17.5 & - & 17.5 \\
\hline 1969 & 0.9 & 0.6 & 1.1 \\
\hline 1970 & 0.9 & 1.5 & 0.3 \\
\hline 1971 & 4.3 & 1.9 & 7.1 \\
\hline 1972 & 5.5 & 1.9 & 9.8 \\
\hline 1973 & 4.1 & 2.2 & 6.4 \\
\hline 1974 & 2.5 & 2.2 & 2.9 \\
\hline 1975 & 2.6 & 2.3 & 3.8 \\
\hline 1976 & 3.0 & 2.0 & 4.9 \\
\hline 1977 & 2.7 & 1.6 & 5.1 \\
\hline 1978 & 5.3 & 2.0 & 11.3 \\
\hline 1979 & 8.4 & 3.0 & 17.5 \\
\hline 1980 & 5.1 & 2.7 & 8.7 \\
\hline 1981 & 4.6 & 3.8 & 6.0 \\
\hline 1982 & 4.2 & 3.6 & 8.8 \\
\hline Overall & 4.5 & 2.3 & 8.4 \\
\hline
\end{tabular}


TABLE A.6. Patent Characteristics of Sodium/Sulfur Assignees

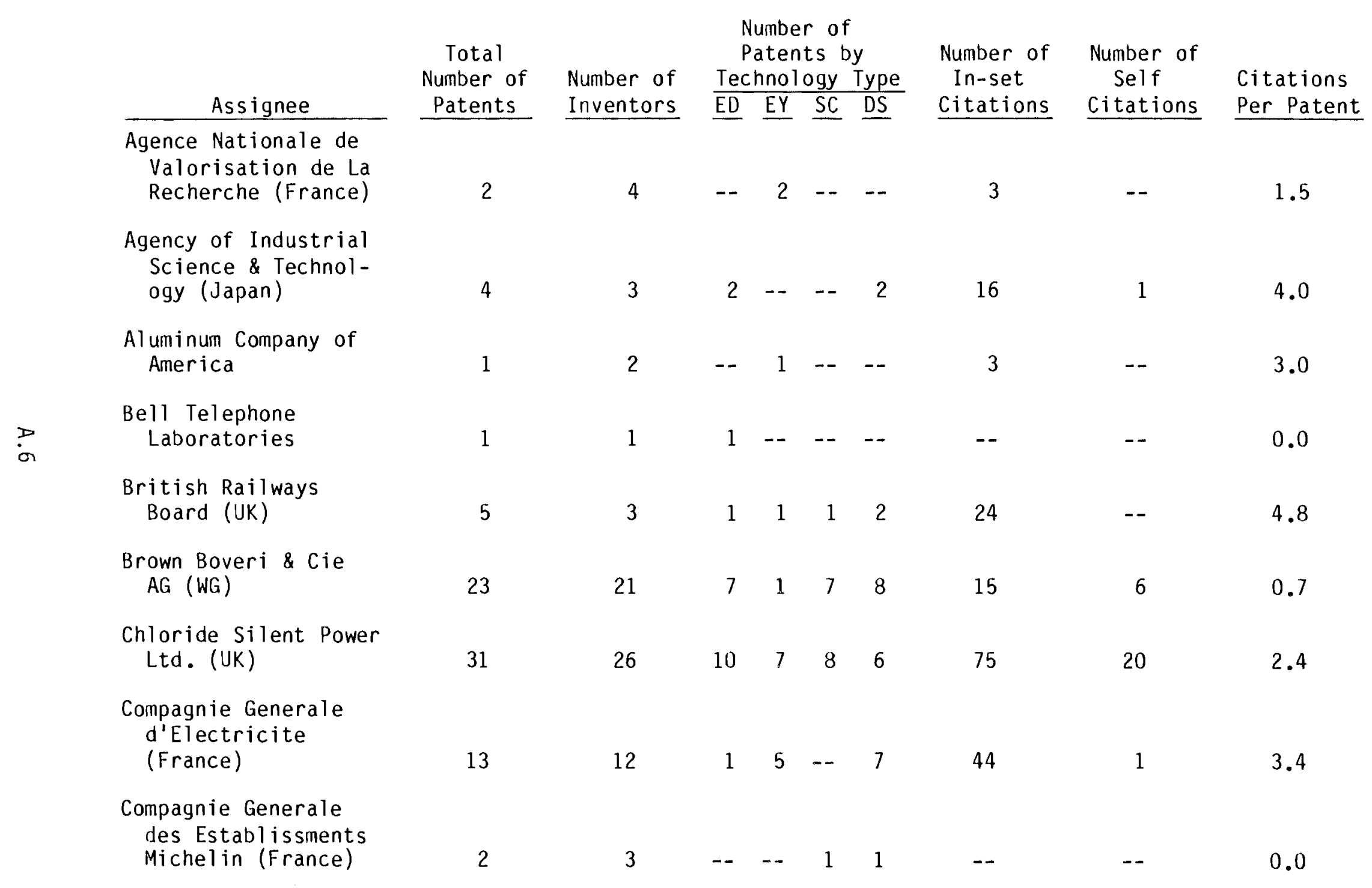


TABLE A.6. (contd)

\begin{tabular}{|c|c|c|c|c|c|c|c|c|c|}
\hline Assignee & $\begin{array}{l}\text { Total } \\
\text { Number of } \\
\text { Patents } \\
\end{array}$ & $\begin{array}{l}\text { Number of } \\
\text { Inventors }\end{array}$ & $\begin{array}{r}\mathrm{P} \\
\mathrm{P} \\
\text { Tec } \\
\mathrm{ED}\end{array}$ & $\begin{array}{l}\text { Imbe } \\
\text { ten } \\
\text { nol } \\
\text { EY } \\
\end{array}$ & $\begin{array}{r}\text { of } \\
\text { ts b } \\
\text { ogy } \\
S C\end{array}$ & $\begin{array}{l}\text { Type } \\
\frac{\text { TyS }}{\underline{D S}}\end{array}$ & $\begin{array}{l}\text { Number of } \\
\text { In-set } \\
\text { Citations } \\
\end{array}$ & $\begin{array}{l}\text { Number of } \\
\text { Self } \\
\text { Citations } \\
\end{array}$ & $\begin{array}{l}\text { Citations } \\
\text { Per Patent } \\
\end{array}$ \\
\hline $\begin{array}{l}\text { Cornell Research } \\
\text { Foundation Inc. }\end{array}$ & 1 & 2 & -- & 1 & -- & -- & 7 & -- & 7.0 \\
\hline Corning Glassworks & 5 & 2 & -- & 1 & 2 & 2 & -- & -- & 0.0 \\
\hline $\begin{array}{l}\text { Deutsche Automobilge- } \\
\text { sellschaft (WG) }\end{array}$ & 2 & 5 & -- & 1 & -- & 1 & 3 & -- & 1.5 \\
\hline Dow Chemical Company & 17 & 12 & 3 & 8 & 1 & 5 & 85 & 26 & 5.0 \\
\hline $\begin{array}{l}\text { E. I. Dupont De Mours } \\
\& \text { Company }\end{array}$ & 5 & 3 & -- & 5 & -- & -- & 4 & -- & 0.8 \\
\hline Eastman Kodak Company & 1 & 1 & -- & 1 & -- & -- & 2 & -- & 2.0 \\
\hline Electric Council (UK) & 9 & 4 & 5 & 3 & -- & 1 & 51 & 4 & 5.7 \\
\hline $\begin{array}{l}\text { Electric Power } \\
\text { Research Institute } \\
\text { Inc. }\end{array}$ & 22 & 10 & 7 & -- & 12 & 3 & 36 & 14 & 1.6 \\
\hline $\begin{array}{l}\text { Engelhard Minerals \& } \\
\text { Chemical Corp. }\end{array}$ & 1 & 1 & -- & 1 & -- & -- & 1 & -- & 1.0 \\
\hline ESB Inc. & 1 & 1 & -- & 1 & -- & -- & 1 & -- & 1.0 \\
\hline $\begin{array}{l}\text { Exxon Research \& } \\
\text { Engineering Company }\end{array}$ & 1 & 1 & -- & 1 & -- & -- & 7 & -- & 7.0 \\
\hline Ford Motor/Aerospace & 45 & 24 & 11 & 6 & 16 & 12 & 223 & 57 & 5.0 \\
\hline
\end{tabular}


TABLE A.6. (contd)

\begin{tabular}{|c|c|c|c|c|c|c|c|c|c|}
\hline Assignee & $\begin{array}{l}\text { Total } \\
\text { Number of } \\
\text { Patents } \\
\end{array}$ & $\begin{array}{l}\text { Number of } \\
\text { Inventors } \\
\end{array}$ & $\begin{array}{r}p \\
\text { Teo } \\
\text { ED } \\
\end{array}$ & $\begin{array}{l}\text { Imbe } \\
\text { ter } \\
\text { inol } \\
\text { EY } \\
\end{array}$ & $\begin{array}{l}r \text { of } \\
\text { ts } b \\
\text { ogy } \\
\text { SC }\end{array}$ & $\begin{array}{l}y \\
\text { Type } \\
\underline{D S}\end{array}$ & $\begin{array}{l}\text { Number of } \\
\text { In-set } \\
\text { Citations } \\
\end{array}$ & $\begin{array}{l}\text { Number of } \\
\text { Self } \\
\text { Citations } \\
\end{array}$ & $\begin{array}{l}\text { Citations } \\
\text { Per Patent }\end{array}$ \\
\hline $\begin{array}{l}\text { General Electric } \\
\text { Company }\end{array}$ & 38 & 24 & 4 & 17 & 15 & 2 & 97 & 24 & 2.6 \\
\hline General Motors & 1 & 2 & -- & 1 & -- & -- & 3 & -- & 3.0 \\
\hline $\begin{array}{l}\text { Great Lakes Carbon } \\
\text { Corp. }\end{array}$ & 2 & 2 & 2 & -- & -- & -- & 1 & -- & 0.5 \\
\hline Hitachi, Ltd. (Japan) & 1 & 3 & -- & 1 & -- & -- & -- & -- & 0.0 \\
\hline $\begin{array}{l}\text { Institute of Gas } \\
\text { Technology }\end{array}$ & 1 & 1 & -- & - & 1 & -- & -- & -- & 0.0 \\
\hline $\begin{array}{l}\text { International Busi- } \\
\text { ness Machines Corp. }\end{array}$ & 1 & 2 & -- & 1 & -- & -- & 1 & -- & 1.0 \\
\hline $\begin{array}{l}\text { Kabushiki Kaisha } \\
\text { Seikosha (Japan) }\end{array}$ & 1 & 2 & -- & 1 & -- & -- & 1 & -- & 1.0 \\
\hline $\begin{array}{l}\text { Kabushiki Kaisha } \\
\text { Toyota (Japan) }\end{array}$ & 6 & 5 & 2 & 4 & -- & -- & 32 & 2 & 5.3 \\
\hline MIT & 2 & 3 & -- & 2 & -- & -- & 5 & 1 & 2.5 \\
\hline Monsanto Company & 1 & 1 & -- & 1 & -- & -- & -- & -- & 0.0 \\
\hline $\begin{array}{l}\text { Nichicon Capacitor } \\
\text { Ltd. (Japan) }\end{array}$ & 1 & 1 & -- & 1 & -- & -- & 1 & - & 1.0 \\
\hline $\begin{array}{l}\text { NKG Spark Plug Ltd. } \\
\text { (Japan) }\end{array}$ & 2 & 2 & -- & 1 & -- & 1 & 6 & 1 & 3.0 \\
\hline
\end{tabular}


TABLE A.6. (contd)

\begin{tabular}{|c|c|c|c|c|c|c|c|c|c|}
\hline \multirow{2}{*}{$\frac{\text { Assignee }}{\begin{array}{c}\text { Owens-Illinois Glass } \\
\text { Inc. }\end{array}}$} & \multirow{2}{*}{$\begin{array}{c}\text { Total } \\
\text { Number of } \\
\text { Patents }\end{array}$} & \multirow{2}{*}{$\begin{array}{c}\text { Number of } \\
\text { Inventors } \\
3\end{array}$} & \multicolumn{3}{|c|}{$\begin{array}{l}\text { Number o } \\
\text { Patents } \\
\text { Technology }\end{array}$} & $\begin{array}{l}\text { by } \\
\text { Type } \\
\text { DS }\end{array}$ & \multirow{2}{*}{$\begin{array}{l}\begin{array}{c}\text { Number of } \\
\text { In-set } \\
\text { Citations }\end{array} \\
\frac{2}{2}\end{array}$} & \multirow{2}{*}{$\begin{array}{l}\begin{array}{c}\text { Number of } \\
\text { Self } \\
\text { Citations }\end{array} \\
\end{array}$} & $\begin{array}{l}\text { Citations } \\
\text { Per Patent }\end{array}$ \\
\hline & & & -- & 1 & -- & -- & & & 2.0 \\
\hline $\begin{array}{l}\text { Phillips Petroleum } \\
\text { Co. }\end{array}$ & 1 & 1 & -- & -- & 1 & -- & -- & -- & 0.0 \\
\hline $\begin{array}{c}\text { Rockwell Interna- } \\
\text { tional Corp. }\end{array}$ & 1 & 1 & -- & 1 & -- & -- & -- & -- & 0.0 \\
\hline $\begin{array}{l}\text { Secretary of State } \\
\text { for Industry (UK) }\end{array}$ & 8 & 10 & 4 & 1 & -- & 3 & 35 & 2 & 4.4 \\
\hline Shell 0il Company & 1 & 2 & -- & 1 & -- & -- & 6 & -- & 6.0 \\
\hline $\begin{array}{l}\text { Societe Anonyme de } \\
\text { Vehicules } \\
\text { Industriels (France) }\end{array}$ & 1 & 1 & -- & -- & -- & 1 & 1 & -- & 1.0 \\
\hline $\begin{array}{l}\text { South African Inven- } \\
\text { tions Development } \\
\text { Corp. (South Africa) }\end{array}$ & 1 & 1 & -- & -- & 1 & -- & -- & -- & 0.0 \\
\hline TRW Inc. & 1 & 3 & -- & 1 & -- & -- & 6 & -- & 6.0 \\
\hline $\begin{array}{l}\text { U.S. Department of } \\
\text { Energy }\end{array}$ & 3 & 5 & -- & 3 & -- & -- & 1 & -- & 0.3 \\
\hline $\begin{array}{l}\text { U.S. Secretary of the } \\
\text { Army }\end{array}$ & 1 & 1 & -- & -- & -- & 1 & 3 & -- & 3.0 \\
\hline
\end{tabular}


TABLE A.6. (contd)

\begin{tabular}{|c|c|c|c|c|c|c|c|c|c|}
\hline Assignee & $\begin{array}{l}\text { Total } \\
\text { Number of } \\
\text { Patents } \\
\end{array}$ & $\begin{array}{l}\text { Number of } \\
\text { Inventors }\end{array}$ & $\begin{array}{r}\mathrm{N} \\
\mathrm{P} \\
\text { Tec } \\
\mathrm{ED} \\
\end{array}$ & $\begin{array}{l}\text { umbe } \\
\text { ten } \\
\text { inol } \\
E Y \\
\end{array}$ & $\begin{array}{l}r \text { of } \\
\text { ts } b \\
\text { ogy } \\
\mathrm{SC} \\
\end{array}$ & $\begin{array}{l}\text { Type } \\
\frac{\text { TS }}{\underline{D S}}\end{array}$ & $\begin{array}{l}\text { Number of } \\
\text { In-set } \\
\text { Citations } \\
\end{array}$ & $\begin{array}{l}\text { Number of } \\
\text { Self } \\
\text { Citations } \\
\end{array}$ & $\begin{array}{l}\text { Citations } \\
\text { Per Patent }\end{array}$ \\
\hline $\begin{array}{l}\text { Unassigned or Indivi- } \\
\text { dually Owned } \\
\text { (one U.S., two WG) }\end{array}$ & 3 & 10 & 1 & -- & 1 & 1 & 11 & -- & 3.7 \\
\hline $\begin{array}{l}\text { United Kingdom Atomic } \\
\text { Energy Authority (UK) }\end{array}$ & 2 & 5 & -- & 1 & -- & 1 & 5 & -- & 2.5 \\
\hline $\begin{array}{l}\text { University of Utah/ } \\
\text { Ceramatec }\end{array}$ & 5 & 9 & 1 & 3 & -- & 1 & 6 & - & 1.2 \\
\hline $\begin{array}{l}\text { Varta Aktiengesel1- } \\
\text { schaft (WG) }\end{array}$ & 2 & 4 & -- & 1 & -- & 1 & -- & -- & 0.0 \\
\hline $\begin{array}{l}\text { Westinghouse Electric } \\
\text { Corp. }\end{array}$ & 3 & 4 & -- & 3 & -- & -- & 1 & 1 & 0.3 \\
\hline $\begin{array}{l}\text { Yuasa Battery Ltd. } \\
\text { (Japan) }\end{array}$ & 2 & 2 & 1 & -- & -- & 1 & 31 & 1 & 15.5 \\
\hline
\end{tabular}


APPENDIX B

PROFILE OF SODIUM/SULFUR BATTERY PATENTS 


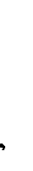




\section{PROFILE OF SODIUM/SULFUR BATTERY PATENTS}

The following pages contain a list of sodium/sulfur battery patents analyzed in this study. The patent set is organized alphabetically by assignee and, within assignees, by patent number. Codes used in this appendix are shown below.

\begin{tabular}{|c|c|c|c|}
\hline $\begin{array}{l}\text { Column } \\
\text { Heading }\end{array}$ & Item & Code & Explanation \\
\hline \multirow[t]{5}{*}{ Sector } & Assignee Sector & 1 & Government \\
\hline & & 2 & Government Supported Contractor \\
\hline & & 3 & Government Contractor Not Supported \\
\hline & & 4 & Other U.S. \\
\hline & & 5 & Foreign \\
\hline \multirow[t]{6}{*}{ Country } & Assignee Country & US & United States \\
\hline & & UK & United Kingdom \\
\hline & & $J P$ & Japan \\
\hline & & FR & France \\
\hline & & $W G$ & West Germany \\
\hline & & SA & South Africa \\
\hline \multirow[t]{4}{*}{ Tech Type } & Technology Type & ED & Electrodes \\
\hline & & EY & Electrolytes \\
\hline & & SC & Sea ls/Containers \\
\hline & & DS & General Design \\
\hline
\end{tabular}


ASSIGNEE

PATENT
NUMBER

PATENT TITLE

AGENCE NATIONALE DE VALORISATION DE LA RECHERCHE FRANCE

4070529
4237201
IONIC CONDUCTIVITY MATERIALS SUITABLE FOR CONSTITUTING SOLID ELECTROLYTE

AGENCY OF INDUSTRIAL SCIENCE \& TECHNOLOGY JAPAN

$\begin{array}{ll}3837918 & \text { SODIUM SULFUR STORAGE BATTERY } \\ 4024319 & \text { SODIUM SULFUR STORAGE BATTERY }\end{array}$

4027075
4076902 SODIUM SULFUR STORAGE BATTERY

ALUMINUM COMPANY OF AMERICA

3859427 PRODUCTION OF BETA ALUMINA

BELL TELEPHONE LABORATORIES

4054728 SODIUM-SULFUR BATTERIES

BRITISH RAILWAYS BOARD ENGLAND

3765945 ELECTRIC CELL AND BATTERIES

3783024 ELECTRIC CELLS AND BATTERIES

3939007 SODIUM SULFUR CELLS

4076903 ALKALI METAL SULFUR CELLS

4104448 ALKALI METAL-SULFUR CELLS

BROWN, BOVERI AND CIE AG. GERMANY

4018969 ELECTROCHEMICAL STORAGE CELL

STORAGE CELL OR BATTERY

4038462 SOLID-ELECTROLYTE BATTERY PARTICULARLY FOR THE STORAGE OF ELECTRICAL ENE

4127705

4184013

4206272

4207386

ELECTROCHEMICAL STROAGE CELL

ELECTROCHEMICAL STROAGE CELL

ELECTROCHEMICAL STORAGE CELL

ELECTROCHEMICAL STORAGE CELL OF BATTERY

ELECTROCHEMICAL STARAGE CELL OR BATTERY OF THE ALKALI METAL ANO SULFUR T

4235956 ELECTROCHEMICAL STORAGE BATTERY

4237200 ELECTROCHEMICAL STORAGE CELL

4238553 ELECTROCHEMICAL STORAGE CELL

4239837 ELECTROCHEMICAL STORAGE CELL

440173

4403023

4405696 ELECTROCHEMICAL STORAGE CELL

ELECTROCHEMICAL STORAGE CELL

ELECTROCHEMICAL STORAGE CELL

THERMAL I NSULATION

4414296 ELECTROCHEMICAL STARAGE CELL OR BATTERY

4414297 SHUNT ELEMENT

4419418 INDIVIDUAL RECHARGEABLE ELECTRIC CELL

4419419 RECHARGEABLE ELECTRIC STARAGE BATTERY

CERAMATEC, INC.

4407912 ELECTROCHEMICAL CELL UTILIZING MOLTEN ALKALI METAL ELECTRODE-REACTANT
FILING

ISSUE

SEC COUN TECH CITA

$7 / 7 / 76$

$1 / 24 / 78$

$\begin{array}{llll}5 & \text { FR } & \text { EY } & 2 \\ 5 & \text { FR } & \text { EY } & 1\end{array}$

$3 / 14 / 73$

$9 / 15 / 75$

$10 / 15 / 76$

$9 / 24 / 74$

$5 / 31 / 77$

$2 / 28 / 78$

$\begin{array}{llll}5 & J P & D S & 12\end{array}$

11/4/71

1/ $7 / 75$

4 US

2/ $9 / 77$

$10 / 18 / 77$

4 US

$11 / 29 / 71$

$11 / 23 / 71$

$1 / 16 / 74$
$7 / 22 / 76$

$10 / 8 / 76$

$10 / 16 / 73$
$1 / 1 / 74$

$2 / 17 / 76$

$2 / 28 / 78$

$8 / 1 / 78$

$\begin{array}{ll}5 & \text { UK } \\ 5 & \text { UK } \\ 5 & \text { UK } \\ 5 & \text { UK } \\ 5 & \text { UK }\end{array}$

$3 / 26 / 76$

$4 / 19 / 77$

$6 / 14 / 77$

$11 / 28 / 78$

$1 / 15 / 80$

$6 / 3 / 80$

$6 / 10 / 80$

$8 / 5 / 80$

$8 / 5 / 80$

9/ $9 / 80$

$12 / 2 / 80$

$12 / 9 / 80$

$12 / 16 / 80$

$6 / 14 / 83$

$8 / 30 / 83$

$9 / 6 / 83$

$9 / 20 / 83$

$11 / 1 / 83$

/18/81

$4 / 23 / 82$

$4 / 23 / 82$

$3 / 26 / 82$

$11 / 8 / 83$

$12 / 6 / 8$

$12 / 6 / 83$

$10 / 13 / 81$

$10 / 4 / 83$

WG ED 3

UK DS

WG ED

WG DS

WG SC

WG ED

WG $D S$

WG ,

WG SC

HG DS

WG WS

WG SC

WG

$S C$

DS

US

ED

0 
ASSIGNEE

PATENT

PATENT TITLE

CHLORIDE SILENT POWER LIMITED GB.

4024321
4048391 ALDALI METAL-SULFUR CELLS

4052535

4055710

4074026

4117056

417209

4118545

412359

4137376

4151235

4167550

4167807

4173686

4212933

4215466

4243733

4291107

4294005

4294897

4348467

4348468

4356241

4365409

4376809

4383013

4396688

4415637

SODIUM SULFUR CELLS

ELECTROCHEMICAL CELLS HAVING SOLID ELECTROLYTE FO TUBULAR FORM

SEALING OF ELECTROCHEHICAL DEVICES UTILIZING LIQUID SODIUM AND A SOLID C SEALING OF ELECTROCHEHICAL DEVI

SOECTO SULPHUL CELLS

CATHODE STRUCTURE FOR SODIUM SULPHUR CELLS

ALKALI METAL SULFUR CELLS

ALKALI METAL SULFUR CELLS

PRODUCTION OF BETA-ALUMINA

METHODS OF MANUFACTURE OF BETA-ALUMINA

SODIUM SULPHUR CELIS

CURRENT COLLECTOR FOR ELECTROCHEMICAL CELLS AND METHOD OF MAKING

METHOD OF SEALING CERAMIC ELECTRLOYTE MATERIAL IN ELECTROCHEMICAL CELLS ELECTRODE STRUCTURES

GLASS SEALS FOR SEALING BETA-ALUMINA IN ELECTROCHEMICAL CELL OF OTHER EN METHOD OF FORMING CATHODIC ELECTRODE STRUCTURE FOR A SODIUM SULFUR CELL SEALING OF CERAMIC ELECTROLYTE TUBES IN ELECTROCHEMICAL CELLS

BETA ALUMINA SOLID ELECTROLYTE MATERIAL AND ITS MANUFACTURE AND ELECTROC SODIUM SULPHUR CELLS

METHOD AND APPARATUS FOR FILLING SODIUM INTO SODIUM SULFUR CELLS SODIUM SULPHUR BATTERIES AND CELL MODULES THEREFOR

SODET TEMPERT MULTICELL ELECTROCHEMICAL STORAGE BATTERIES

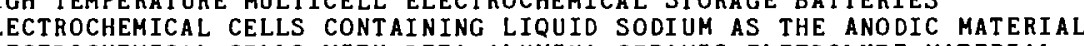

DELT

COMPAGNIE GENERALE D'ELECTRICITE FRANCE

3748178 ELECTROCHEMICAL GENERATOR OF THE SODIUM-SULFUR TYPE

3758337 SODIUM SULFUR ACCUMULATOR WITH TEMPERATURE CONTROLLING MEANS

4037027

4037028

4041216

4064209

4076900

4125682

4137287

4211570

4330496
4332866

SODIUM SULFUR ELECTRIC CELL AND METHOD OF FORMING SAME

SODIUM SULFUR TYPE ELECTRIC CELL

SODIUM-SULFUR BATTERY MORE PARTICULARLY FOR ELECTROCAL DRIVE

SOCIU-SULFUR ELECTRIC CELL

METHOD OF CONNECTING AN ALKALI BETA ALUMINA PART TO AN ALPHA ALUMINA PAR SODIUM-SULFUR TYPE ELECTRIC CELL

DETHM-SULFUR ELECTRIC CELL C

METHOD OF PREPARING BETA ALKALINE ALUMINA PARTS

METHOD OF MANUFACTURTNG BETA ALKALINE ALUMINA PARTS

METHOD OF STINTERING TUBULAR CERAHIC PARTS

METHOD OF TEMPERATURE REGULATION

COMPAGNIE GENERALE DES ETABLISSMENTS MICHELIN, SOCIALE MICHELIN-CIE FRAN

4212931 ARRANGEMENT COMPRISING A COMPARTMENT AND A CONDUI

4216273 ELECTROCHEMICAL DEVICE WITH SOLID SEPARATOR AND SOLID ELECTROLYTE
FILING

DATE

ISSUE

SEC COUN TECH CITA-

$12 / 15 / 75$

$6 / 28 / 76$

$4 / 23 / 76$

$8 / 19 / 76$

$10 / 1 / 76$

$3 / 9 / 77$

1/21/77

91577

$6 / 20 / 77$

$10 / 31 / 77$

$8 / 4 / 77$

$1 / 18 / 78$

$5 / 15 / 78$

$9 / 14 / 78$

$5 / 22 / 78$

$5 / 3 / 78$

$8 / 27 / 7$

4/15/80

$5 / 23 / 79$

$3 / 25 / 80$

$7 / 7 / 81$

$12 / 17 / 80$

$7 / 7 / 81$

$7 / 14 / 81$

(1/14/8

$3 / 15 / 82$

$5 / 17 / 77$

$5 / 17 / 77$

$9 / 13 / 77$
$10 / 4 / 77$

$10 / 25 / 77$

$2 / 14 / 78$

$9 / 26 / 78$

$10 / 3 / 78$

$10 / 31 / 78$

$11 / 7 / 78$

$1 / 30 / 79$

$9 / 11 / 79$

$9 / 18 / 79$

1/ $6 / 79$

$7 / 15 / 80$
$8 / 5 / 80$

$1 / 6 / 81$

9/22/81

9/ $7 / 82$

$9 / 7 / 82$

$10 / 26 / 82$

$3 / 15 / 83$

$8 / 2 / 83$

11/ $8 / 83$

$11 / 15 / 8$

$\begin{array}{ccr}\text { UK } & \text { SC } & 11 \\ \text { UK } & \text { SC } & 7 \\ \text { UK } & \text { ED } & 22 \\ \text { UK } & \text { ED } & 4 \\ \text { UK } & \text { EY } & 2 \\ \text { UK } & \text { SC } & 1 \\ \text { UK } & \text { EY } & 2 \\ \text { UK } & \text { SC } & 4 \\ \text { UK } & \text { ED } & 3 \\ \text { UK } & \text { ED } & 2 \\ \text { UK } & \text { DS } & 2 \\ \text { UK } & \text { DS. } & 4 \\ \text { UK } & \text { EY } & 2 \\ \text { UK } & \text { EY } & 0 \\ \text { UK } & \text { DS } & 1 \\ \text { UK } & \text { ED } & 2 \\ \text { UK } & \text { SC } & 1 \\ \text { UK } & \text { SC } & 1 \\ \text { UK } & \text { ED } & 0 \\ \text { UK } & \text { SC } & 1 \\ \text { UK } & \text { ED } & 1 \\ \text { UK } & \text { SC } & 2 \\ \text { UK } & \text { ED } & 0 \\ \text { UK } & \text { EY } & 0 \\ \text { UK } & \text { EY } & 0 \\ \text { UK } & \text { DS } & 0 \\ \text { UK } & \text { DS } & 0 \\ \text { UK } & \text { DS } & 0 \\ \text { UK } & \text { ED } & 0 \\ \text { UK } & \text { EY } & 0 \\ \text { UK } & \text { ED } & 0\end{array}$

$10 / 22 / 71$

$7 / 24 / 73$

$9 / 11 / 73$

$7 / 19 / 77$

$8 / 9 / 77$

9/20/77

$12 / 20 / 77$

$2 / 28 / 78$

$11 / 14 / 78$

$1 / 30 / 79$

$7 / 8 / 80$

$5 / 18 / 82$
$6 / 1 / 82$

$\begin{array}{ll}5 & F R \\ 5 & F R \\ 5 & F R \\ 5 & F \\ 5 & F R \\ 5 & F \\ 5 & F \\ 5 & F R \\ 5 & F R \\ 5 & F R \\ 5 & F R \\ 5 & F R \\ 5 & F R\end{array}$

$F R$
$F R$
$F R$
$F R$
$F R$
$F R$
$F R$
$F R$
$F R$
$F R$
$F R$
$F R$
$F R$

EY

DS

DS

DS

DS

ES

ED

EY 0

$1 / 21 / 8$

$7 / 15 / 80$

$7 / 19 / 78$
$12 / 4 / 78$

$8 / 5 / 80$

$\begin{array}{ll}5 & F R \\ 5 & \end{array}$ 
CORNELL RESEARCH FOUNDATION INC.

$7 / 9 / 75$

$5 / 25 / 76$

us

CORNING GLASSWORKS

4310607 BATTERY CELL CONSTRUCTION

4311772 SEALING GLASSES FOR ELECTROCHEMICAL, ELECTRICAL, ELECTRONIC AND OPTICLA

4347295 SEALING GLASSES FOR ELECTROCHEMICAL, ELECTRICAL, ELECTRONIC AND OPT ICAL AP

4375503 SODIUM ION CONDUCTING GLASSES AND BÁTTERIES EMBODYING GLASSES

4387505 METHOD OF FORMING A BATTERY CELL

$7 / 11 / 80$

$10 / 9 / 80$

$8 / 20 / 81$
$11 / 4 / 81$

$1 / 12 / 82$

$1 / 19 / 82$

$8 / 31 / 82$

$3 / 1 / 83$
$6 / 14 / 83$

DEUTSCHE AUTOMOBILGESELLSCHAFT GMBH GERMANY

4230778 SODIUM-SULFUR BATTERY WITH GLASS ELECTROLYTE

4237196 SODIUM ION-CONDUCTING GLASS ELECTROLYTE FOR SODIUM SULFUR BATTERIES

$3 / 16 / 79$

$10 / 28 / 80$

DOW CHEMICAL COMPANY

3476602 BATTERY CELL

3663294 BATTERY EMPLOYING AN ALKALI METAL POLYSULFIDE HAVING A LOW ALKaLI METAL

3672995

3672995

3749603

3765944

3829331

3877995

SOLID ELECTROLYTE FOR ELECTROCAL CELLS

ALKALI METAL-SULFUR BATTERY HAVING A CATHODIC CURRENT COLLECTOR COATED BATTERY HAVING A MOLTEM ALKALI METAL POLYSULFIDE CATHODE ANO CORBON COAT SODIUM BORATE GLASS COMPOSITIONS AND BATTERIES CONTAINING SAME

POTASSIUM BORATE GLASS COMPOSITIONS

4050915

4112203

METHOD OF GRINDING SOLDER GLASSES

4170695

ALKALI METAL/SULFUR BATTERY

4219613
4224386

4226921

SELECTIVE PLUGGING OF BROKEN FIBERS IN TUBESHEET-HOLLOW FIBER ASSEMBLIES HELIUM FIBER TYPE TUBESHEET FOR HOLLOW FIBER TYPE BATTERY CELLS AND METH TUBESHEET FOR HOLLOW FIBER TYPE, HIGH TEMPERATURE BATTERY CELLS

SELECTIVE PLUGGING OF BROKEN FIBERS IN TUBESHEET-HOLLOW FIBER ASSEMBLIES

4332868 HY PASS FOR INTERNALLY OPEN-CIRCUITED CELLS
HIGH TERMPERATURE BATTERY CELL COMPRISING STRESS-FREE HOLLOW FIBER BUNDL

E.I. DUPONT DE NEMOURS AND COMPANY

4097345 NA5GDSI 4012 AND RELATED RARE EARTH SODIUM ION CONDUCTORS AND ELECTROLYT

4181579

4190500

SODIUM ION CONDUCT ING SODIUM ALUMINUM PHOSPHATE GLASSES

SODIUM ION CONDUCTING SODIUM BOROPHOSPHATE GLASS

TMAN KODAK COMPANY

4083919 BETA-ALUMINA COMPOSITES ANO METHODS FOR PRODUCING THEM

ELECTRIC COUNCIL ENGLAND

3903225
3922176
3

3950463 PRODUCTION OF BETA-ALUMINA CERAMIC TUBER

3953227

3953227
3982957

4059663

4061840

ELECTROCHEMICL CELLS HAVING A LIQUID ALKALI METAL ELECTRODE AND SOLID EL

SODIUM SULFUR CELLS

SODIUM SULFUR CELLS

$7 / 1 / 70$

$5 / 8 / 69$

$5 / 17 / 72$

$11 / 26 / 71$

$12 / 30 / 71$

$12 / 3 / 73$

$10 / 4 / 76$

$4 / 21 / 77$

$9 / 22 / 77$

$7 / 18 / 79$

$7 / 16 / 79$

$8 / 13 / 79$

9/ $1 / 78$

$12 / 28 / 80$

$11 / 4 / 69$

$5 / 16 / 72$

$7 / 25 / 72$

$7 / 31 / 73$

$10 / 16 / 73$

$8 / 13 / 74$

$11 / 4 / 75$

$9 / 27 / 77$

9/ $5 / 78$

$8 / 26 / 80$

$8 / 23 / 80$

$10 / 7 / 80$

$2 / 24 / 81$
$6 / 1 / 82$

$10 / 15 / 76$

$6 / 19 / 78$

$6 / 19 / 78$

$4 / 6 / 79$
$7 / \quad 2 / 79$

$6 / 27 / 78$

$1 / 1 / 80$

$2 / 26 / 80$

$6 / 3 / 80$

4/ 4/76

$4 / 11 / 78$

$12 / 28 / 71$

1/ $2 / 74$

$5 / 9 / 72$
$9 / 20 / 74$

$2 / 14 / 75$

$12 / 8 / 75$

9/ 2/75

$11 / 25 / 75$

4/13/76

$9 / 28 / 76$

$11 / 22 / 77$
WG DS

US EY 18

US

US

US

US

EY . US

US

EY

UK

UK 
ASSIGNEE

PATENT

PATENT TITLE

ELECTRIC COUNCIL ENGLAND

$\begin{array}{ll}4066826 & \text { SODIUM SULPHUR CELLS } \\ 4129690 & \text { SODIUM SULPHUR CELLS }\end{array}$

ELECTRIC POWER RESEARCH INSTITUTE. INC.

4048390 NA/S CELL REACTANT CONTAINER WITH METAI

4049885 SONSTRUCTION FOR SOLID ELECTROLYTE IN SODIUM/SULFUR

4053689 CONTACT BETWEEN METAL CAN AND CARBON/GRAPHITE FIBERS IN SODIUM/SULFUR CE

4070527

4123566

4124740

4131226

414683

4189530

4189531

4204035

4218524

4219128

4220691

4232098

药

4234668

4246325
4266712 EFFICIENT SODIUM-SULFUR BATTER

SOCIUM SULFUR CELL CASING

TINER WITH METAL ALUMINIDE COATING

SODIUM SULFUR BATTERY

CINER CONSTRUCTION AND METHOD OF MANUFACTURE

SOLTUM CELL CONSTRUCT ION ANO METHOD

A DOUBLE CARBON MAT-COMPOSITE

TINER FOR A SODIUM-SULFUR CELL AND METHOD

CONTAINER WITH PROTECTIVE RESIN COATING

IN-SITU PREPT CONTAINER FOR A SODIUM-SULFER CELL AND ITS METHOD OF USE

SULFUR ELECTRODE CONTAINER CONSTRUCT ION AND METHOD OF MANUFACTURE

SODIUM SULFUR CELL

CODIUM SULFUR CELL COMPONENT PROTECTED BY A HIGH CHROMIUM ALLOY AND MEHT SOMPOSITE SULFUR ELECTRODE CONTAINER AND METHOD OF MANUFACTURE

SODIUM SULFUR BATTERY INCLUDING THERMALLY RESPONSIVE VALUE AND METHOD

METHOD OF MAKING A SULFUR ELECTRODE CONTAINER

4287664 SOOLUM-SULFUR CELL WITH METHOD OF CONSTRUCTING THE SULFUR ELECTRODE

4193954 BETA ALUMINA MANUFACTURE

ESB INCORPORATED

3718505 SODIUM-SULFUR BATTEWRY HAVING ALUMINUM SULFIDE OR ALUMINUM POLYSULFIED I

EXXON RESEARCH AND ENGINEERING COMPANY

3895963 PROCESS FOR THE FORMATION OF. BETA ALUMINA-TYPE CERAMICA

FORD AEROSPACE \& COMMUNICATIONS CORP.

4170694 HERMATECALLY SEALED ALKALI METAL BATTERY CONTAINER

FORD MOTOR COMPANY

3404035 SECONDARY BATTERY EMPLOYING MOLTEN ALKALI METAL REACTANT

3404036 ENERGY CONVERSION DEVICE COMPRISING A SOLID CRYSTALLINE ELECTROLYTE AND

3413150

3446677

3468709

3468719

3475220

3475225

3719531 BATTERY HAVING A MOLTEN ALKALI METAL ANODE

SECONDARY SOLID STATE IONIC CONDUCTOR AND METHOD OF MAKING

SECONDARY BATTERY

METHOD FOR PREPARING SOLID STATE IONIC CONDUCTOR

THELTRODES AND MOVABLE SOLIO ELECTR

CATIONICALLY CONDUCTIVE CERAMICS, THEIR PREPARATION AND USE

\begin{tabular}{|c|c|c|c|c|c|}
\hline $\begin{array}{l}\text { FILING } \\
\text { DATE }\end{array}$ & $\begin{array}{l}\text { ISSUE } \\
\text { DATEE }\end{array}$ & $\begin{array}{l}\text { SEC } \\
\text { TOR }\end{array}$ & $\begin{array}{l}\text { COUN } \\
\text {-TRY }\end{array}$ & $\begin{array}{l}\text { TECH } \\
\text { TYPE }\end{array}$ & $\begin{array}{l}\text { CITA- } \\
\text { TIONS }\end{array}$ \\
\hline $\begin{array}{r}9 / 8 / 76 \\
10 / 13 / 77\end{array}$ & $\begin{array}{r}1 / 3 / 78 \\
12 / 12 / 78\end{array}$ & $\begin{array}{l}5 \\
5\end{array}$ & $\begin{array}{l}\text { UK } \\
\text { UK }\end{array}$ & $\begin{array}{l}\text { ED } \\
\text { ED }\end{array}$ & $\begin{array}{l}2 \\
0\end{array}$ \\
\hline $\begin{array}{r}12 / 20 / 76 \\
10 / 12 / 76 \\
12 / 20 / 76 \\
8 / 13 / 76 \\
6 / 15 / 77 \\
6 / 23 / 77 \\
12 / 27 / 77 \\
9 / 28 / 77 \\
11 / 4 / 77 \\
2 / 1 / 79 \\
9 / 25 / 78 \\
10 / 26 / 78 \\
9 / 25 / 78 \\
4 / 9 / 79 \\
10 / 10 / 78 \\
9 / 25 / 78 \\
3 / 22 / 78 \\
4 / 20 / 78 \\
7 / 3 / 79 \\
3 / 31 / 80 \\
1 / 18 / 80 \\
10 / 22 / 79\end{array}$ & $\begin{array}{r}9 / 13 / 77 \\
9 / 20 / 77 \\
10 / 11 / 77 \\
1 / 24 / 78 \\
8 / 29 / 78 \\
10 / 31 / 78 \\
11 / 7 / 78 \\
12 / 26 / 78 \\
3 / 27 / 79 \\
2 / 12 / 80 \\
2 / 19 / 80 \\
2 / 19 / 80 \\
5 / 20 / 80 \\
8 / 19 / 80 \\
8 / 26 / 80 \\
9 / 2 / 80 \\
11 / 4 / 80 \\
11 / 18 / 80 \\
1 / 20 / 81 \\
5 / 12 / 81 \\
3 / 16 / 81 \\
9 / 8 / 81\end{array}$ & $\begin{array}{l}4 \\
4 \\
4 \\
4 \\
4 \\
4 \\
4 \\
4 \\
4 \\
4 \\
4 \\
4 \\
4 \\
4 \\
4 \\
4 \\
4 \\
4 \\
4 \\
4 \\
4 \\
4\end{array}$ & $\begin{array}{l}\text { US } \\
\text { US } \\
\text { US } \\
\text { US } \\
\text { US } \\
\text { US } \\
\text { US } \\
\text { US } \\
\text { US } \\
\text { US } \\
\text { US } \\
\text { US } \\
\text { US } \\
\text { US } \\
\text { US } \\
\text { US } \\
\text { US } \\
\text { US } \\
\text { US } \\
\text { US } \\
\text { US } \\
\text { US }\end{array}$ & $\begin{array}{l}S C \\
D S \\
E D \\
E D \\
S C \\
S C \\
S C \\
S C \\
E D \\
\text { ED } \\
S C \\
S C \\
D S \\
E D \\
S C \\
\text { ED } \\
S C \\
\text { SC } \\
D S \\
S C \\
E D \\
S C\end{array}$ & $\begin{array}{l}2 \\
3 \\
3 \\
4 \\
8 \\
0 \\
1 \\
6 \\
0 \\
0 \\
1 \\
0 \\
0 \\
0 \\
0 \\
1 \\
2 \\
2 \\
1 \\
0 \\
1 \\
1\end{array}$ \\
\hline $3 / 27 / 78$ & $3 / 18 / 80$ & 4 & US & EY & 1 \\
\hline $12 / 7 / 71$ & $2 / 27 / 73$ & 4 & US & EY & 1 \\
\hline $12 / 20 / 72$ & $7 / 22 / 75$ & 3 & US & EY & 7 \\
\hline $12 / 4 / 78$ & $10 / 9 / 79$ & 3 & US & SC & 3 \\
\hline $\begin{array}{r}10 / 22 / 65 \\
5 / 2 / 66 \\
9 / 28 / 66 \\
11 / 21 / 66 \\
4 / 3 / 67 \\
11 / 21 / 66 \\
6 / 22 / 67 \\
11 / 21 / 66 \\
4 / 3 / 67 \\
12 / 22 / 69\end{array}$ & $\begin{array}{r}10 / 1 / 68 \\
10 / 1 / 68 \\
11 / 26 / 68 \\
5 / 27 / 69 \\
9 / 23 / 69 \\
9 / 23 / 69 \\
10 / 28 / 69 \\
10 / 28 / 69 \\
5 / 26 / 70 \\
3 / 6 / 73\end{array}$ & $\begin{array}{l}3 \\
3 \\
3 \\
3 \\
3 \\
3 \\
3 \\
3 \\
3 \\
3\end{array}$ & $\begin{array}{l}\text { US } \\
\text { uS } \\
\text { uS } \\
\text { us } \\
\text { uS } \\
\text { us } \\
\text { us } \\
\text { us } \\
\text { us } \\
\text { us }\end{array}$ & $\begin{array}{l}\text { DS } \\
\text { DS } \\
D S \\
\text { EY } \\
D S \\
\text { EY } \\
D S \\
\text { EY } \\
\text { DS } \\
\text { EY }\end{array}$ & $\begin{array}{r}28 \\
21 \\
31 \\
7 \\
7 \\
6 \\
4 \\
4 \\
8 \\
3\end{array}$ \\
\hline
\end{tabular}


ASSIGNEE

PATENT

PATENT TITLE

FORD MOTOR COMPANY

FT56856 FLEXABLE SEALING MATERIAL FOR ENERGY CONVERSIN DEVICES

3811943 MASS TRANSPORTATION ELECTRODE FOR ENERGY CONVERSION DEVICE

3966492 SODIUM SULFUR BATTERY OR CELL WITH IMPROVED WMPERE-HOUR CAPACITY

3976503 PROCESS FOR RECHARGING SECONDARY BATTERIES

3980496 ENERGY CONVERSION DEVICES WITH IMPROVED ELECTRODE SHAPES

3985576 SEAL FOR ENERGY CONVERSION DEVICES

3993503 SECONDARY BATTERY OR CELL WITH CC

\begin{tabular}{l}
3993503 \\
3994745 \\
SECONDARY BATTERY OR CELL WITH COMPOSITE ELECTRODE \\
4002806 \\
SECONDARY BATTERY WITH SEPARATE CHARGE AND DISCHARGE ZONES \\
\hline
\end{tabular}

4002807

4038465

4048393

4048394

4056589

405658

4084041

4091151

4091190

4102042

4110515

4117208

4166156

4169919

4192911

4197363

4226923

4239838

4245012

4247605

4248943

4290192

4375127

SECONDARY BATTERY OR CELL

ALKALI METAL SULFUR BATTERY OR CELL WITH SINGLE PHASE SULFUR ELECTRODE

SODIUM SULFUR BATTERY OR CELL WITH EXTERNAL STORAGE

ALKALI METAL BATTERY STRUCTURE

VITEOUS CARBON COATED GRAPHITE CURRENT CO METHODICALLY SEALED CLKALI METAL BATTERY CONTAINER

ELLETRODE

SECONDARY BATTERY OR CELL WITH POYSULFIDE WETTABLE ELECTRODE

SECONDARY BATTERY OR CELL WITH IMPROVED RECHARGEABILITY

HERMETICALLY SEALED ALKALI METAL BATTERY CONTAINER

MEHTOD FOR PREPARING A SODIUM/SULFUR CELL

METHOD OF PREPARING COMPOSITE BODY AND SECONDARY BATTERTY OF CELL INCORP

ELECTRICAL CONVERSION DEVICE WITH CERAMIC ELECTRODE

SECONDARY BATTERY OR CELL WITH PYROLYTIC GRAPHITE COATED GRAPHITE CURREN SECONOARY BATTERY OR CELL WITH PYROLYTI

DODIUM SULFUR BATTERY SEAL

SODIUH SUL SODIUM SULFUR BATTERY

EAL FOR SODIUM SULFUR BATTERY

SODIUM CONVERSION DEVICE WIT

NG A SODIUM SULFUR

SODIUM SULFUR CONTIANER WITH CHROMIUM/CHROMIUM OXIDE COATING

METHOD OF MAKING A SODIUM SULFUR BATTERY

GENERAL ELECTRIC COMPANY

3533848

3579382

3607405

3607435

3607436

3625773

36729

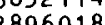

10018

3900381

3928071

3933523

3946751

SEALED CONTAINER FOR ELEMENTAL SODIUM

SEALED CONTAINER FOR ELEMENTAL SODIUM
METHOD OF MAKING SINTERED BETA-ALUMINA BODIES

SINTERED BETA-ALUMINA BODIES AND METHOD

METHOD OF PRODUCING BETA-ALUMINA ELECTROLYTES

DUR CELL WITH THIRD ELECTRODE

CASING AND HERMETICALLY SEALED PRIMARY SODIUM-SULFUR CELL

METHOD OF FORMING BETA-ALUMINA ART ICLES

METHOD OF FORMING BETA-ALUMINA ARTICLES

METHOD OF FORMING BETA-ALUMINA ARTICLES

OF FLY SEALED PRIMARY BATTERY

CTERO WITH LIOUID METALLIC LAYER

CELL CASING WITH A HERMETIC MECHANICAL SEAL ANO A HERMETICALLY SEALED SO
FILING

DATE

ISSU

SEC COUN TECH CITA-

$1 / 2 / 7$

2/16/71

$8 / 20 / 75$
$8 / 20 / 75$

$4 / 14 / 75$

$1 / 29 / 75$

$2 / 18 / 76$
$1 / 30 / 76$

$1 / 30 / 76$
$1 / 30 / 76$

$8 / 20 / 75$

$9 / 30 / 75$

(117/75

$9 / 2377$

$9 / 1 / 76$

$2 / 18 / 76$

(2)

$9 / 15 / 77$

$5 / 23 / 77$

$3 / 11 / 77$

$2 / 28 / 77$

$9 / 15 / 77$

$2 / 28 / 77$

$1 / 1 / 78$

$10 / 26 / 78$

$10 / 29 / 79$

2/ $5 / 79$

$8 / 28 / 7$

4/ 7/80

$4 / 21 / 80$

$12 / 20 / 79$
$9 / 5 / 80$

$5 / 21 / 74$

$6 / 29 / 76$

$8 / 24 / 76$

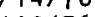

$11 / 23 / 76$

$1 / 30 / 76$

1/11/77

1/11/77

9/13/77

/13/77

$11 / 1 / 77$

$4 / 11 / 78$

$4 / 11 / 78$

$5 / 23 / 78$

$5 / 23 / 78$

$8 / 29 / 78$

$9 / 26 / 78$

$8 / 28 / 79$

$3 / 11 / 80$

4/ $8 / 80$

10/ $7 / 80$

$1 / 13 / 81$

$1 / 27 / 81$

2/ 3/81

$9 / 22 / 81$
$3 / \quad 1 / 83$

US

US SC

SC 10

US

US

US

$5 / 18 / 71$

$9 / 21 / 71$

$9 / 21 / 71$

$9 / 21 / 71$
$12 / 7 / 71$

$6 / 27 / 72$

$12 / 3 / 74$

$7 / 22 / 75$
$7 / 22 / 75$

$8 / 19 / 75$

$8 / 23 / 75$
$1 / 20 / 76$

$1 / 20 / 76$

$3 / 30 / 76$ 
ASS IGNEE

PATENT

PATENT TITLE

3959013 CATHODE CELL CASING PORTION. A CELL CASING, AND A HERMETICALLY SEALED SO

3960596

3976554
4012563

4073711

4084040

4109063

4247

4135040

4140841

4142945

4197171

4209573

423666

426831

4291108

4302519

4307138

4341849

4374701
4381216

4381968

BATTERY CASING AND HERMETICALLY SEALED SODIUM-SULFUR BATTERY

METHOD OF FORMING BETA-ALUMINA ART ICLES

SEALD LITHIUH-SODIUM ELECTROCHEMICAL CELL WITH SODIUM BETA-ALUMINA ELEC METHOD OF PRODUCING LITHIATED BETA ALUMINA ART ICLES

CELL CASING AND A HERMETICALLY SEALED SODIUM-SULFUR CELL

COMPOSITE SOLID ELECTROLYTE BODY

SOLID ION-CONDUCTIVE ELECTROLYTE BODY AND METHOD OF FORMING

SULFUR ELECTRODE, SULFUR ELECTRODE CONTAINER AND METHODS OF MANUFACTURE

METHOD OF FORMING A COMPOSITE BODY AND METHOD OF BONDING

SOLID ELECTROLYTE MATERIAL COMPOSITE BODY, AND METHOD OF BONDING

SULFUR ELECTRODE CONTAINER AND METHODS OF MANUFACTURE

METHOD OF BONDING A COMPOSITE BODY TO A METALLIC ELEMENT

THERMOCOMPRESSION METHODS OF FORMIN

SODIUM RESISTANT SEALING GLASSES

PRODUCTION OF BETA-ALUMINA CERAMIC TUBES

PINTECTON OF B-ALUMINA CERAMIC TUBES

SINTERED ION-CONDUCTIVE COMPOSITE ELECTROLYTE OF BETA-ALUMINA AND B"-ALU SODIUM RESISTANT SEALING GLASSES

GENERAL MOTORS

METHOD OF ETCHING TO FORM CATIONICALLY-CONDUCTIVE CERAMIC BODY

ETCHED BETA"-ALUMINA CERAMIC ELECTROLYTE

4052538

METHOD OF MAKING SODIUM BETA-ALUMINA POWDER AND SINTERED ARTICLES

GREAT LAKES CARBON CORP.

4127634 SULFUR GRAPHITE FIBER ELECTROOE FOR SODIUM-SULFUR BATTERIES

4169120 SULFUR ELECTRODE FOR SODIUM-SULFUR BATTERIES

4390460 LITHIUM OXIDE BASED AMORPHOUS MATERIAL AND PROCESS FOR PREPARATION THERE

INST ITUTE OF GAS TECHNOLOGY

4226922 SODIUM SULFUR ELECTROCHEMICAL CELL OR BATTERY

INTERNATIONAL BUSINESS MACHINES CORP

4024214 METHOD OF PREPARING BETA AL203

KABUSHIKI KAISHA DAINI SEIKOSHA JAPAN

3963522 METHOD OF IMPROVED TREATMENT RELATING TO THE SURFACE OF THE ELECTROLYTE

KABUSHIKI KAISHA TOYOTA CHUO KENKYUSHO JAPAN

3655845 HEATING A SINTERES ALUMINA ARTICLE IN ATMOSPHERE CONTAINING SODIUM OR PO 3707589 REHEATING A BETA-ALUMINA ARTICLE IN AN ALDALI METAL ATMOSPHERE TO IMPROV

3743543 SEPARATOR FOR CONTROLLING ALKALI METAL ION FLOW IN AN ELECTRODE ACTIVE $M$

3915741
SODIUM-SULFER CELL WITH IMPROVED SEPARATO
FILING

DATE

$\begin{array}{llll}\text { ISSUE } & \text { SEC COUN TECH CITA- } \\ \text { DATE } & \text { TOR } & - \text { TRY TYPE } & \text { TIONS }\end{array}$

$6 / 11 / 75$

$12 / 31 / 75$

$11 / 22 / 76$

$2 / 28 / 77$

$1 / 17 / 77$

$3 / 20 / 78$

$5 / 11 / 78$

$10 / 24 / 78$

4/10/78

$11 / 6 / 78$

$4 / 21 / 80$

$8 / 25 / 80$

$8 / 25 / 80$

$5 / 23 / 80$

$3 / 2 / 81$

$8 / 3 / 81$

$8 / 3 / 81$
$8 / 3 / 81$

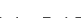

$6 / 1 / 76$

$8 / 24 / 76$

$2 / 14 / 78$

$4 / 11 / 7$

$11 / 7 / 78$

$2 / 26 / 78$

$2 / 20 / 79$

$2 / 20 / 79$
$3 / 6 / 79$

$4 / 8 / 80$

$6 / 24 / 80$

12/ $2 / 80$

$5 / 19 / 81$

$9 / 22 / 8$

$12 / 22 / 81$

$7 / 27 / 82$

$2 / 22 / 83$

$4 / 26 / 83$
$5 / 3 / 83$

\section{US}

US

US

$4 / 19 / 76$

10/ 4/77

1/ 4/78

$11 / 28 / 78$

US

$5 / 15 / 78$

$9 / 25 / 79$

$9 / 28 / 81$

$6 / 28 / 83$

$5 \mathrm{~J}$

$8 / 9 / 79$

$10 / 7 / 80$

4 US

$2 / 17 / 76$

$5 / 17 / 77$

4 US

$11 / 13 / 74$

$6 / 15 / 7$

$5 \mathrm{JP}$

$7 / 29 / 69$

4/13/71

$9 / 29 / 70$

$10 / 17 / 73$
$7 / 17 / 74$

4/11/7

$12 / 26 / 7$

$7 / 3 / 73$

$5 / 13 / 75$
$10 / 28 / 75$ 
ASSIGNEE

PATENT

PATENT TITLE

KABUSHIKI KAISHA TOYOTA CHUO KENKYUSHO JAPAN

4021255 SINTERED BETA-ALUMINA ARTICLE PERMEABLE TO SODIUM AND POTASSIUM IONS AND

MIT 4049891 COMPOSITION FOR FAST ALKALI-METAL-ION TRANSPORT 4166159 PROCESS FOR FORMING FAST SODIUM-ION TRANSPORT COMPOSITIONS

MONSANTO COMPANY 4348458 COILED INORGANIC MONOLITHIC HOLLOW FIBERS

NICHICON CAPACITOR LIMITED JAPAN 3687735 METHOD OF MANUFACTURING A SOLID ION CONDUCTIVE COMPOSITION

NKG SPARK PLUG CO., LTD. JAPAN

4082826 PROCESS FOR PRODUCING HIGHLY ION-CONDUCTIVE PORCELAIN 4279974 SOLID ELECTROLYTE MATERIAL AND USE THEREOF

OWENS-ILLINOIS GLASS INC 4041215 METHOD FOR FORMING SOLID ELECTROLYTE COMPOSITE

SOCIETE ANONYME DE VEHICULES INDUSTRIELS ET D'EQUIPMENTS MACHANIQUES SAV 4230780 SODIUM SULFUR ELECTRIC CELL

SOUTH AFRICAN INVENTIONS DEVELOPMENT CORP.

4269905 ELECTROCHEMICAL CELL AND THE PROTECTION OF AN ELECTROCHEMICAL CELL

TRW INC.

3901733 THIN FILM SOLID ELECTROLYTE STRUCTURES AND PROCESS OF MAKING SAME

\begin{tabular}{|c|c|c|c|c|c|}
\hline $\begin{array}{l}\text { FILING } \\
\text { DATE }\end{array}$ & $\begin{array}{l}\text { ISSUE } \\
\text { DATE }\end{array}$ & $\begin{array}{l}\text { SEC } \\
\text { TOR }\end{array}$ & $\begin{array}{l}\text { COUN } \\
\text {-TRY }\end{array}$ & $\begin{array}{l}\text { TECH } \\
\text { TYPE }\end{array}$ & $\begin{array}{l}\text { CITA- } \\
\text { TIONS }\end{array}$ \\
\hline $2 / 14 / 75$ & $5 / 3 / 77$ & 5 & $J P$ & EY & 1 \\
\hline $\begin{array}{l}6 / 21 / 76 \\
8 / 2 / 78\end{array}$ & $\begin{array}{l}9 / 20 / 77 \\
8 / 28 / 79\end{array}$ & $\begin{array}{l}2 \\
3\end{array}$ & $\begin{array}{l}\text { US } \\
\text { US }\end{array}$ & $\begin{array}{l}\text { EY } \\
\text { EY }\end{array}$ & $\begin{array}{l}3 \\
2\end{array}$ \\
\hline $9 / 8 / 80$ & $9 / 7 / 82$ & 4 & uS & EY & 0 \\
\hline $1 / 5 / 70$ & $8 / 29 / 72$ & 5 & $J P$ & EY & 1 \\
\hline $\begin{array}{l}5 / 19 / 77 \\
3 / 19 / 80\end{array}$ & $\begin{array}{l}4 / 4 / 78 \\
7 / 21 / 81\end{array}$ & $\begin{array}{l}5 \\
5\end{array}$ & $\begin{array}{l}\mathrm{JP} \\
\mathrm{JP}\end{array}$ & $\begin{array}{l}\text { EY } \\
\text { DS }\end{array}$ & $\begin{array}{l}5 \\
1\end{array}$ \\
\hline $4 / 5 / 76$ & $8 / 9 / 77$ & 4 & US & EY & 2 \\
\hline $3 / 21 / 78$ & $10 / 23 / 79$ & 4 & US & SC & 0 \\
\hline $10 / 16 / 81$ & $11 / 9 / 82$ & 3 & US & EY & 0 \\
\hline $\begin{array}{r}4 / 29 / 75 \\
3 / 7 / 75 \\
6 / 30 / 75 \\
11 / 17 / 75 \\
7 / 6 / 76 \\
11 / 17 / 75 \\
6 / 30 / 75 \\
3 / 22 / 76\end{array}$ & $\begin{array}{l}1 / 13 / 76 \\
9 / 28 / 76 \\
2 / 1 / 77 \\
6 / 14 / 77 \\
7 / 12 / 77 \\
9 / 23 / 77 \\
9 / 23 / 77 \\
1 / 10 / 78\end{array}$ & $\begin{array}{l}5 \\
5 \\
5 \\
5 \\
5 \\
5 \\
5 \\
5\end{array}$ & $\begin{array}{l}\text { UK } \\
\text { UK } \\
\text { UK } \\
\text { UK } \\
\text { UK } \\
\text { UK } \\
\text { UK } \\
\text { FR }\end{array}$ & $\begin{array}{l}\text { DS } \\
D S \\
E D \\
E D \\
E D \\
E D \\
D S \\
E Y\end{array}$ & $\begin{array}{r}10 \\
8 \\
4 \\
7 \\
1 \\
0 \\
2 \\
2 \\
3\end{array}$ \\
\hline $3 / 29 / 72$ & $3 / 5 / 74$ & 4 & US & EY & 6 \\
\hline $10 / 22 / 79$ & $10 / 28 / 80$ & 5 & FR & DS & 1 \\
\hline $11 / 28 / 79$ & $5 / 26 / 81$ & 5 & & SC & 0 \\
\hline $10 / 7 / 7$ & $8 / 26 / 75$ & 4 & US & EY & 6 \\
\hline
\end{tabular}




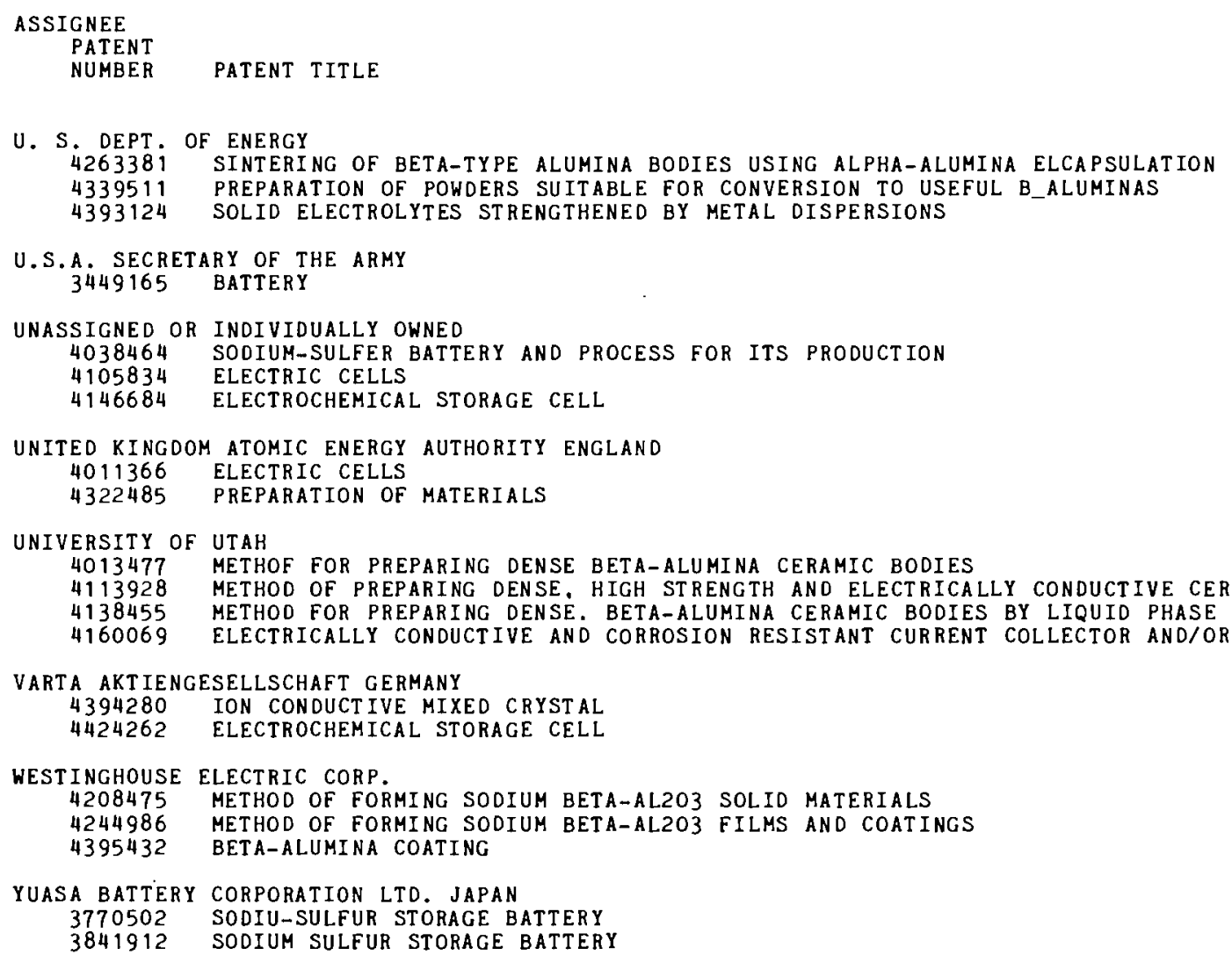

$\begin{array}{lllll}\text { FILING } & \text { ISSUE } & \text { SEC } & \text { COUN TECH } & \text { CITA- } \\ \text { DATE } & \text { DATE } & \text { TOR } & \text {-TRY TYPE } & \text { TIONS }\end{array}$

$\begin{array}{llllll}10 / 27 / 78 & 4 / 21 / 81 & 1 & \text { US } & \text { EY } & 1 \\ 4 / 16 / 81 & 7 / 1 / 82 & 1 & \text { US } & \text { EY } & 0 \\ 10 / 5 / 81 & 7 / 12 / 83 & 1 & \text { US } & \text { EY } & 0 \\ & & & & & \\ 2 / 9 / 68 & 6 / 10 / 69 & 1 & \text { US } & \text { DS } & 3 \\ & & & & & \\ 11 / 26 / 75 & 7 / 26 / 77 & 5 & \text { WG } & \text { OS } & 3 \\ 10 / 3 / 77 & 8 / 8 / 78 & 4 & \text { US } & \text { SC } & 3 \\ 7 / 20 / 77 & 3 / 27 / 79 & 5 & \text { WG } & \text { ED } & 5 \\ & & & & & \\ 5 / 11 / 76 & 3 / 8 / 77 & 5 & \text { UK } & \text { OS } & 4 \\ 6 / 5 / 80 & 3 / 30 / 82 & 5 & \text { UK } & \text { EY } & 1 \\ & & & & & \\ 7 / 30 / 75 & 3 / 22 / 77 & 2 & \text { US } & \text { EY } & 3 \\ 4 / 18 / 77 & 9 / 12 / 78 & 2 & \text { US } & \text { EY } & 1 \\ 4 / 15 / 77 & 2 / 6 / 79 & 2 & \text { US } & \text { EY } & 1 \\ 2 / 18 / 77 & 7 / 3 / 79 & 2 & \text { US } & \text { DS } & 1 \\ & & & & & \\ 4 / 19 / 82 & 7 / 19 / 83 & 5 & \text { WG } & \text { EY } & 0 \\ 10 / 21 / 81 & 1 / 3 / 84 & 5 & \text { WG } & \text { DS } & 0 \\ & & & & & \\ 12 / 28 / 78 & 6 / 17 / 80 & 2 & \text { US } & \text { EY } & 0 \\ 4 / 24 / 79 & 1 / 13 / 81 & 2 & \text { US } & \text { EY } & 1 \\ 12 / 16 / 81 & 7 / 26 / 83 & 3 & \text { US } & \text { EY } & 0 \\ & & & & & \\ 8 / 11 / 72 & 11 / 6 / 73 & 5 & \text { JP } & \text { ED } & 17 \\ 4 / 2 / 73 & 10 / 15 / 74 & 5 & \text { JP } & \text { DS } & 14\end{array}$


" 


\section{DISTRIBUTION}

No. of

Copies

\section{OFFSI TE}

T. M. Levinson

U.S. Department of Energy Energy Conversion and Utilization Technologies Division C..-14

1000 Independence Avenue, S.W. Washington, DC 20585

J. E. Duinn

U.S. Department of Energy

Energy Storage Technologies

Division

CE-14

1000 Independence Avenue, S.W. Washington, $\mathrm{NC} 20585$

A. R. Landgrebe, Chief

IJ.S. Department of Energy

Electrochemical Storage Rranch

CE-14

1000 Independence Avenue, S.W. Washington, חC 20585

M. E. Gunn

U.S. Department of Energy

Energy Conversion and Utilization Technologies nivision

CE-14

1000 Independence Avenue, S.W. Washington, DC 20585

J. J. Eberhardt

U.S. Department of Energy

Energy Conversion and Utilization Technologies Division CE-14

1000 Independence Avenue, S.W. Washington, DC 20585
No. of

Copies

J. J. Brogan, Director

II.S. Department of Energy

Office of Energy Systems

Research

CE-14

1000 Independence Avenue, S.W. Washington, DC 20585

R. S. Kirk, Chief

U.S. Department of Energy

Office of Vehicle \& Engine R\&D

CE-132

1000 Independence Avenue, S.W. Washington, DC 20585

S. Ruby

U.S. Department of Energy

Electrochemical Storage Branch

CE -14

1000 Independence Avenue, S.W. Washingt on, DC 20585

P. J. Brown

U.S. Department of Energy

Office of Vehicle \& Engine R\&D CE-13?

1000 Independence Avenue, S.W. Washington, DC 20585

M. H. Chiogiogi

II.S. Department of Energy

office of Vehicle \& Engine R\&n

CE-13

1000 Independence Avenue, S.W. Washington, DC 20585

D. T. Farrell

U.S. Department of Energy

Electrochemical Energy Storage CE-141, MS 5E-036

1000 Independence Avenue, S.W. Washington, DC 20585 
No. of

Copies

K. R. Friedman

U.S. Department of Energy

CE-132

1000 Independence Avenue, S.W.

Washington, DC 20585

K. W. Klein

U.S. Department of Energy

CE-14

1000 Independence Avenue, S.W.

Washington, DC 20585

T. J. Gross

U.S. Department of Energy

Office of Industrial Programs

CE-12?

1000 Independence Avenue, S.W. Washington, D.C. 20585

R. Meredith

U.S. Department of Energy

Electrochemical Energy Storage

CE-141, MS 5E-036

1000 Independence Avenue, S.W. Washington, DC ?.0585

T. P. Sheahen

IJ.S. Department of Energy

Energy Research Advisory Board 1000 Independence Avenue, S.W. Washingt on, DC 20585

30 DOE Technical Information Center

J. Christian

Science Indicators IInit

National Science Foundation

1800 G St., NW

Washington, D.C. 20550

R. I. Schoen

National Science Foundation

1800 G St., N.W.

Room 1250

Washington, DC 20550
No. of

Copies

\section{J. Myers}

U.S. Patent \& Trademark Office CM2-313

Washington, DC 20231

E. J. Cairns

Lawrence Berkeley Laboratory

Bldg. 90, Rm. 3026

1 Cyclotron Road

Berkeley, CA 94720

R. P. Clark

Sandia National Laboratory

P.0. Box 5800, Div. 2525

Albuquerque, NM 87185

K. Grothaus

Sandia National Laboratory

P.n. Box 5800, Div. 2525

Albuquerque, NM 87185

K. Kinoshita

Lawrence Berkeley Laboratory

1 Cyclotron Road

Berkeley, CA 94720

\section{R. Abarcar}

Energetics, Inc.

9? 10 Route 108

Columbia, MD 21045

F. McLarnon

Lawrence Rerkeley Laboratory

Bldg. 90, Room 3026

1 Cyclotron Road

Berkeley, CA 94720

N. J. Magnani

Sandia National Laboratory

P.0. Box 5800, Dept. 2520

Albuquerque, NM 87185

E. Brooman

Battelle-Columbus Laboratory

$505 \mathrm{King}$ Avenue

Columbus, $\mathrm{OH} 43201$ 
No. of

Copies

H. R. Hamilton

Rattelle-Columbus Laboratory 505 King Avenue

Columbus, $\mathrm{OH} 43201$

G. Stacey

Battelle-Columbus Laboratory

505 King Avenue

Columbus, $\mathrm{OH} 43201$

R. S. Weaver

Electric Power Research Institute

3412 Hillview Avenue

Palo Alto, CA 94303

J. Birk

Electric Power Research

Institute

3412 Hillview Avenue

P.ก. Box 10412

Palo Alto, CA 94303

R. J. Brodd

Amoco Research Center

P. O. Box 400

Naperville, IL 60566

F. R. Kalhammer

Electric Power Research

Institute

3412 Hillview Avenue

P.0. Box 10412

Palo Alto, CA 94303

R. S. Gordon

Cerametec, Inc.

163 West 1700 South

Salt Lake City, UT 84115
No. of

Copies

ONSITE

DOE Richland Operations

H. E. Ransom

64 Pacific Northwest Laboratory

W. B. Ashton (40)

J. E. Danko

J. R. Divine

J. L. Eisenhauer

E. A. Eschbach

R. M. Fleischman

G. J. Hane

P. E. Hart

H. Harty

C. J. Hostick

J. W. Hurwitch

C. H. Imhoff

B. L. Mohler

L. O. Levine

R. K. Sen

M. B. Triplett

C. Winter

L. D. Williams

Publishing Coordination MH (2)

Technical Information (5) 